University of Louisville

ThinkIR: The University of Louisville's Institutional Repository

Electronic Theses and Dissertations

$5-2012$

\title{
Advising style perceptions and preferences of students and advisors.
}

Gladys Patricia Brown Jordan

University of Louisville

Follow this and additional works at: https://ir.library.louisville.edu/etd

\section{Recommended Citation}

Jordan, Gladys Patricia Brown, "Advising style perceptions and preferences of students and advisors." (2012). Electronic Theses and Dissertations. Paper 714.

https://doi.org/10.18297/etd/714

This Doctoral Dissertation is brought to you for free and open access by ThinkIR: The University of Louisville's Institutional Repository. It has been accepted for inclusion in Electronic Theses and Dissertations by an authorized administrator of ThinkIR: The University of Louisville's Institutional Repository. This title appears here courtesy of the author, who has retained all other copyrights. For more information, please contact thinkir@louisville.edu. 


\title{
ADVISING STYLE PERCEPTIONS AND PREFERENCES OF STUDENTS AND ADVISORS
}

\author{
By \\ Gladys Patricia Brown Jordan \\ B.A., Western Kentucky University, 1999 \\ M.B.A., Western Kentucky University, 2002
}

\begin{abstract}
A Dissertation
Submitted to the Faculty of the

College of Education and Human Development of the University of Louisville in Partial Fulfillment of the Requirements for the Degree of

Doctor of Philosophy

Department of Leadership, Foundations and Human Resource Education University of Louisville Louisville, Kentucky
\end{abstract}

May 2012 
Copyright 2012 by Gladys Patricia Brown Jordan

All rights reserved 
ADVISING STYLE PERCEPTIONS AND PREFERENCES OF STUDENTS AND ADVISORS

\section{By}

Gladys Patricia Brown Jordan

B.A., Western Kentucky University, 1999

M.B.A., Western Kentucky University, 2002

A Dissertation Approved on

April 10, 2012

by the following Dissertation Committee

Dr. Sam Evans

Dissertation Chair

Dr. John L. Keedy

Dr. Joseph M. Petrosko, Jr.

Dr. Retta E. Poe

Dr. Douglas C. Smith 


\section{DEDICATION}

This dissertation is dedicated to my parents

David E. Brown, Jr.

and

Kathryn Pauline Hardy Brown

who guided with love and instilled a love for reading, education, and lifelong learning. 


\section{ACKNOWLEDGMENTS}

I would like to thank my dissertation chair, Dr. Sam Evans, for knowing (and reminding me) that I could accomplish this and for understanding the trials of working with a non-traditional student. I would like to thank Dr. Doug Smith, for his tireless help and always positive attitude. I offer a special thank you to Dr. Retta Poe whose keen eye and helpful suggestions made this dissertation much better. I would also like to thank my other committee members, Dr. John Keedy, and Dr. Joseph Petrosko - your time and help have been invaluable.

Most of all, I want to thank my husband, Lee, for understanding, being patient, and always having my back. Also, thanks to my children, Lee, Kasey, Jennifer, and Jacob, and to my grandchildren Jonathan Lee, William Austin, Caleb Michael, Caleb Finn, Marcelino Mateo, Juliana Grace, Aidan Todd, and Gabriella Kaelin for understanding when I had to study.

Finally, to Dr. Bob Reber - I could not have done this without your support and faith and I thank you. 


\title{
ABSTRACT \\ ADVISING STYLE PERCEPTIONS AND PREFERENCES \\ OF STUDENTS AND ADVISORS
}

\author{
Gladys Patricia Brown Jordan
}

May 11, 2012

The best style of advising to offer students has been questioned over and over. The literature review revealed uncertainty related to national surveys of advisors and students and encouraged smaller institutional reviews.

The Academic Advising Inventory (Winston and Sandor, 1984b), was administered to a proportionate to size random sample of advisors (faculty and professional) and then to the advisees of the advisors who responded to the survey. Variables of interest for advisors included age, gender, type (faculty or professional), and college. Variables of interest for students included gender, ethnicity, age, classification, generational status, and GPA.

A standard multiple regression, one-way Analysis of Variance (ANOVA), bivariate analysis, and a difference of proportions test were used to answer six research questions. Post hoc analysis was done with the Scheffé post hoc test.

Significant findings for advisors included differences by advisor type relative to preference for advising style delivered $(F(1,39)=5.174, p=.029)$ and for advising style preferred $(F(1,39)=8.360, p=.006)$. Professional advisors had a stronger developmental orientation than faculty advisors. Gender was also a significant factor $(F(1,39)=4.635, p=$ .038 ) in preference for advisors with females indicating a more developmental style than males. Significant findings related to the advising students received included college $\left(\chi^{2}(6, n\right.$ 
$=286), p=.000)$, gender $\left(\chi^{2}(1, n=293), p=.031\right)$, classification $\left(\chi^{2}(4, n=294), p=.043\right)$, and being non-White $\left(\chi^{2}(1, n=272), p=.013\right)$. Females and White students indicated a preference for more developmental advising. The level of developmental advising preferred increased with changes in student classification. For example, seniors preferred more developmental advising than freshmen.

Students and advisors were asked to complete five survey questions related to satisfaction with advising. The majority of advisor respondents were satisfied with advising and how well they advised. There was some concern over whether advising was included in tenure decisions and the amount of time available for advising. Student responses showed overall satisfaction. A term called mismatch was created by measuring the difference between students' preferred advising style (as measured on the AAI continuum) and the measure of the advising they received. Bivariate analysis was used to examine differences in satisfaction scores based on a mismatch with advising. The findings were significant $\left(\chi^{2}(3, n\right.$ $=279), p=.000)$.

The results of the study are not generalizable; however, they do point to several areas for future research. There is a population of students on campus who have indicated they are not receiving the style of advising they would prefer to receive. The incongruence can lead to lower levels of satisfaction and possibly a retention problem. 
TABLE OF CONTENTS

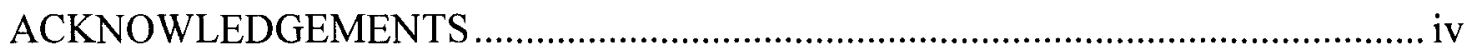

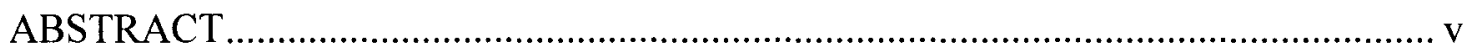

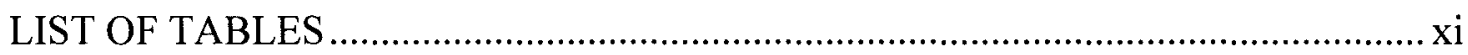

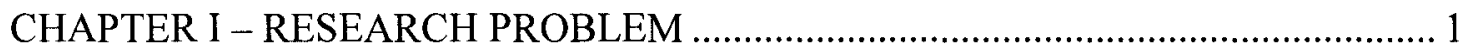

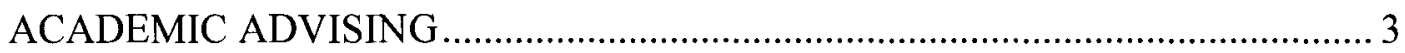

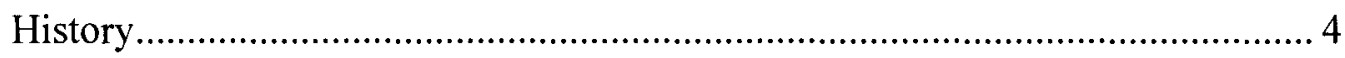

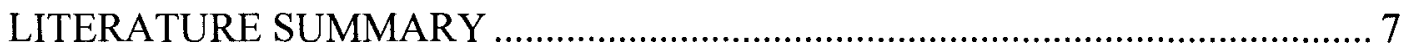

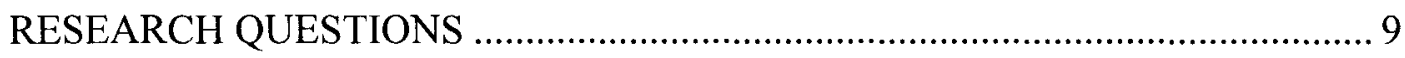

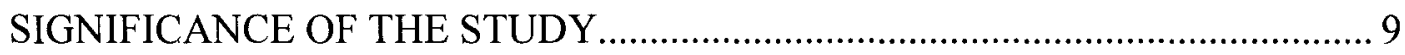

CHAPTER II - REVIEW OF THE LITERATURE............................................... 11

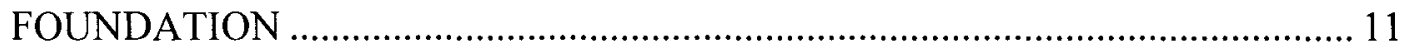

COGNITIVE- AND PSYCHOSOCIAL-DEVELOPMENTAL THEORIES .......... 13

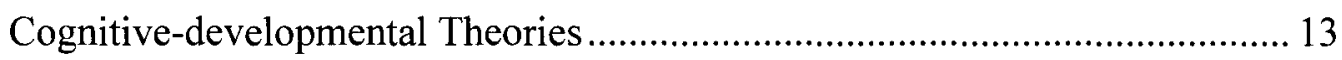

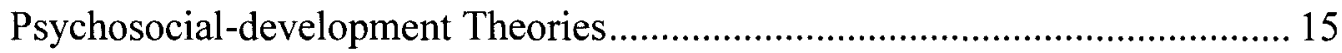

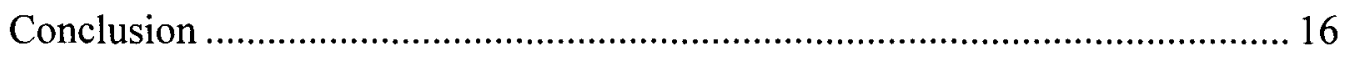

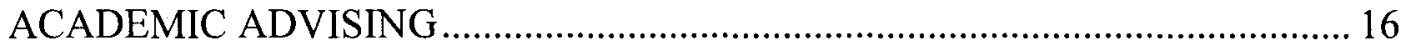

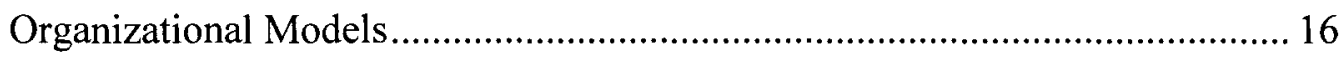

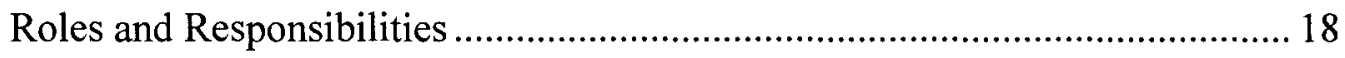

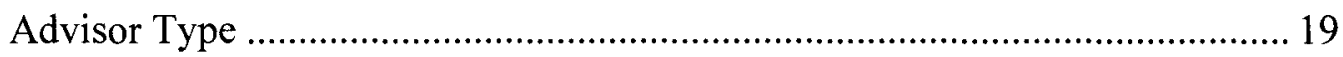

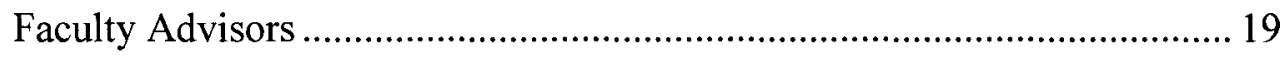


Professional Advisors

Student Preference for Faculty or Professional Advisor.............................. 25

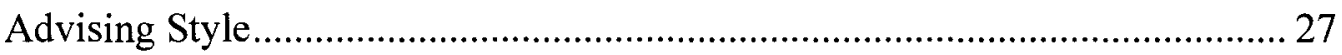

Congruence between Advising Style Received and Preferred by Students....... 31

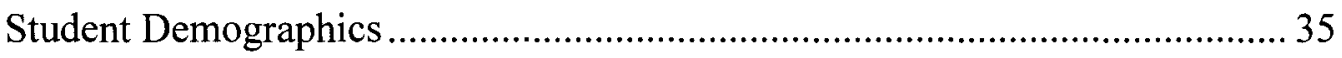

First-generation Students ............................................................................. 41

CONCLUSION

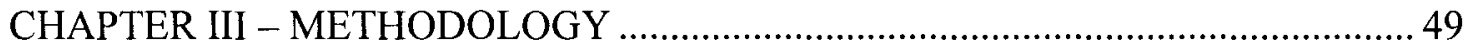

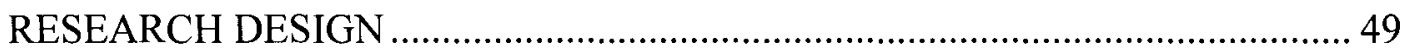

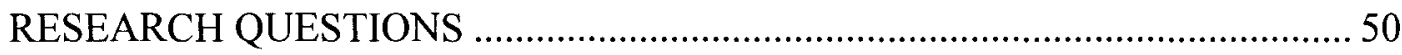

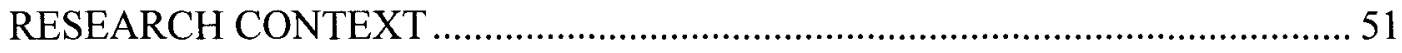

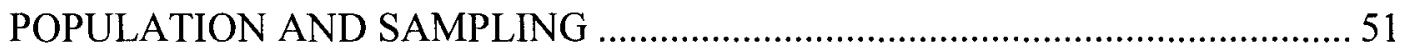

Experience with Research Personnel ............................................................... 52

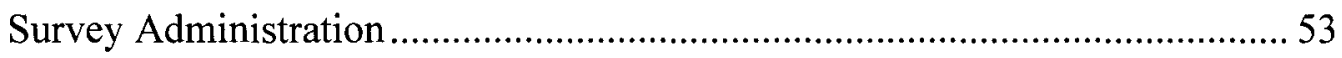

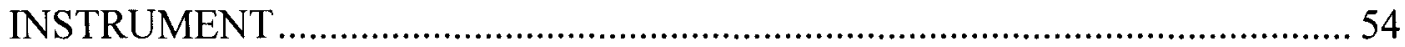

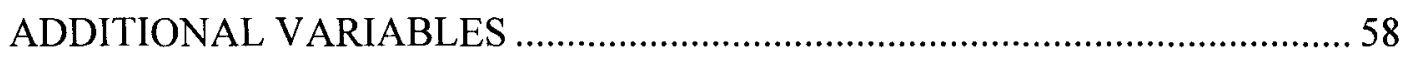

Student Demographic Variables .................................................................. 58

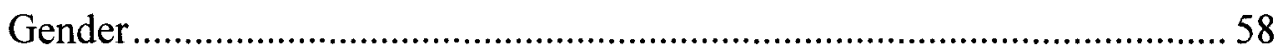

Age

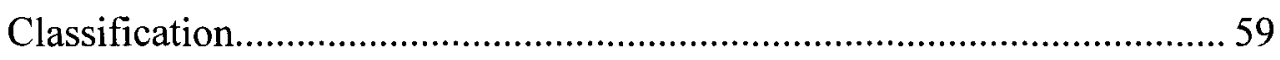

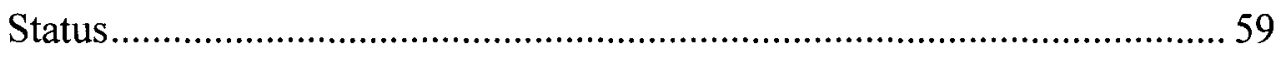

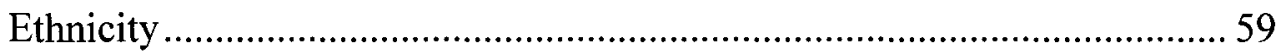

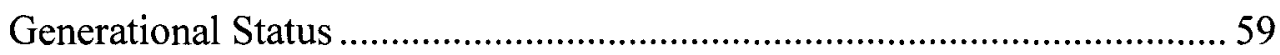


Advisor Demographic Variables (type, age, gender, college) ............................ 60

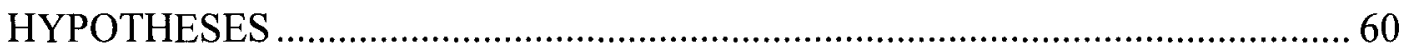

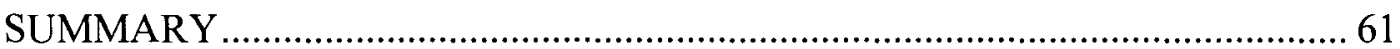

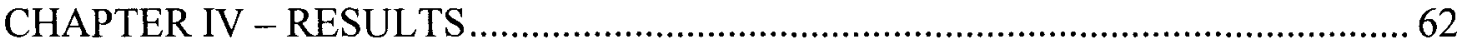

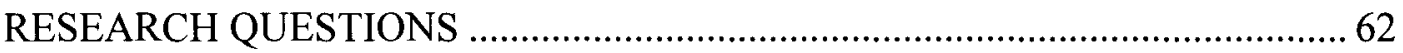

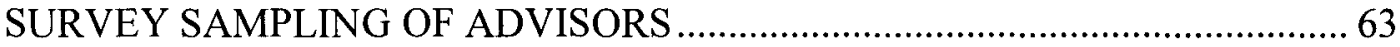

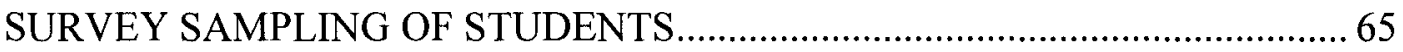

ADDITIONAL DESCRIPTIVE STATISTICS …………....................................... 69

Advisor Sample

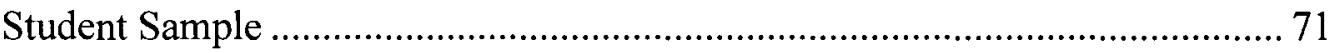

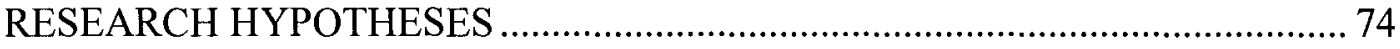

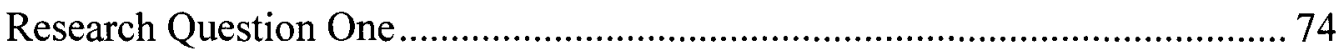

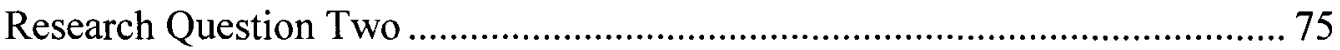

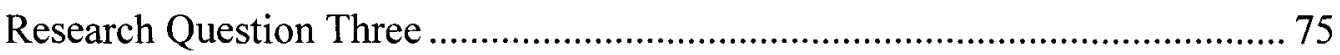

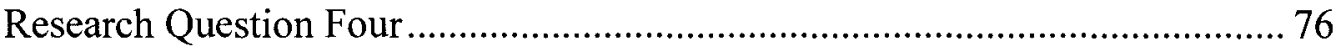

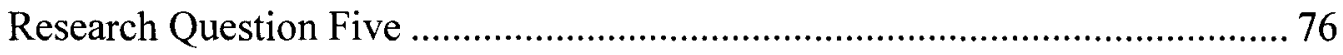

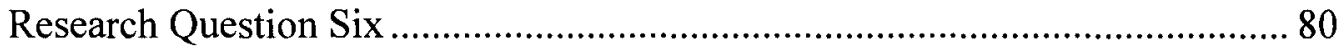

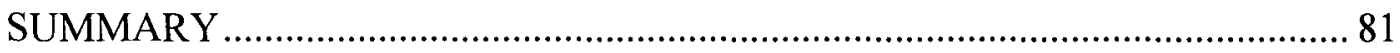

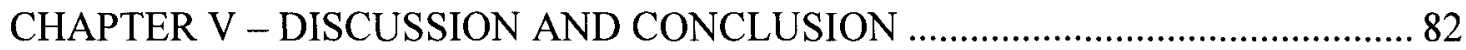

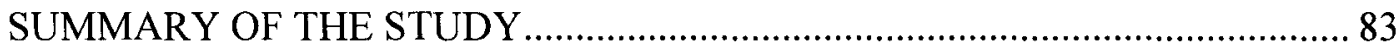

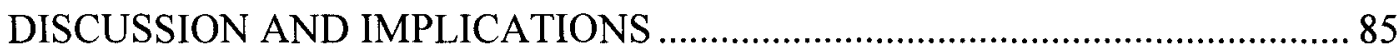

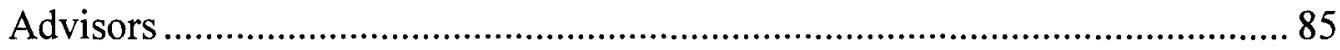

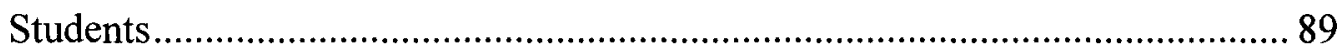




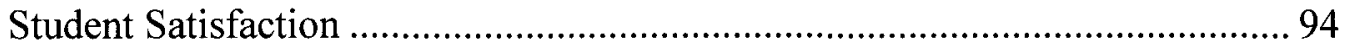

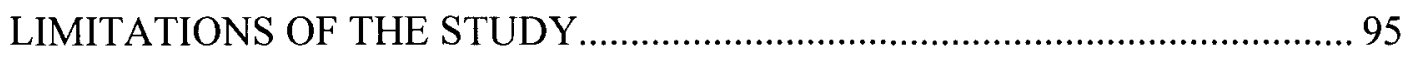

CONCLUSIONS AND SUGGESTIONS FOR FUTURE RESEARCH ................97

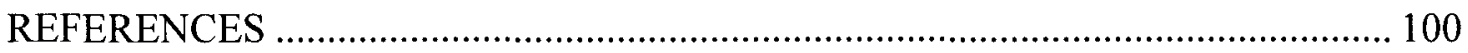

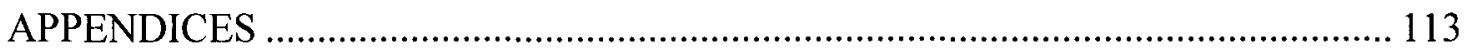

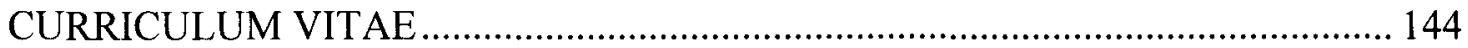




\section{LIST OF TABLES}

TABLE

PAGE

1. Advisor Gender, Advisor Type, and Participants by College. .65

2. Student Gender and Age 67

3 Student Race/Ethnicity .67

4. Student Classification, Status, Generational Status, and GPA ............................68

5. Years as Advisor on Campus and Overall .................................................. 70

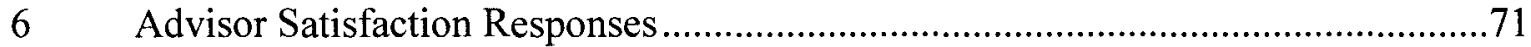

7. Student Advising Received - Campus, College, Department, Advisor and Outside .72

8. Student Respondents by College .............................................................73

9. Student Satisfaction Responses...............................................................74

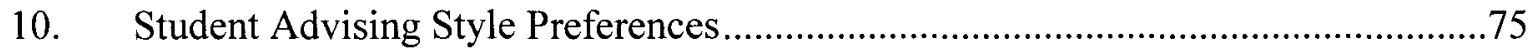

11. Regression of Student Preference on Selected Sociodemographic Variables ..........77

12. Crosstabulation - Mismatch of Preferred Advising Style by Style Received ..........78

13. Crosstabulation - Satisfaction Statement One by Mismatch..............................78

14. Crosstabulation - Satisfaction Statement Two by Mismatch ...............................79

15. Crosstabulation - Satisfaction Statement Three by Mismatch .............................79

16. Crosstabulation - Satisfaction Statement Four by Mismatch ...............................79

17. Crosstabulation - Satisfaction Statement Five by Mismatch ..............................80 
18. Analysis of Variance - Advising Style Delivery Preference by Advisor Gender ....81

19. Analysis of Variance - Advising Style Delivery Preference by Advisor Type.........81 


\section{CHAPTER I \\ RESEARCH PROBLEM}

As the world grows more interconnected and the globalization of education and industry increases, so does the need for the United States to have more educated citizens. The United States is no longer considered the leader of nations in education. According to Lee and Rawls (2010), the U. S. fell from first place to sixth, as of 2007, in the share of adults aged 25-64 years holding associate degrees or higher.

The relative decline in degrees held does not appear to relate to the number of students entering colleges and universities. In fact, Lee and Rawls (2010) reported that in 2007 more than one-half (67.2\%) of high school graduates were enrolled in two- or fouryear institutions in the fall following their graduation. Of these enrollees, $68.3 \%$ of females entered from high school, as compared with $66.1 \%$ of males. Family income influenced decisions to attend college. Only $55 \%$ of students classified as coming from low income homes began college immediately following high school, while $63.3 \%$ of middle income and $78.2 \%$ of high income students entered.

Parental education level also was a variable in who entered college right from high school. Only $50.9 \%$ of students whose parents possessed a high school diploma or less entered. A higher percentage of students whose parents had at least some college (65.2\%) entered, as did $85.8 \%$ of those whose parents held a bachelor's degree or higher (Lee \& Rawls, 2010). 
Although more students now enter institutions of higher education, retention and graduation continue to pose a challenge. As of $2007,78.0 \%$ of full-time students across the nation who entered public four-year colleges as degree-seeking students were retained from the freshman to the sophomore year. Overall, only $56.1 \%$ who entered an institution of higher education intent on earning a bachelor's degree persisted to graduation within six years or less. Concern over declining retention is not a recent development (Lee \& Rawls, 2010).

Traditionally, revenue for state institutions of higher education stemmed, in part, from state funding based upon the number of students enrolled. Over time that criterion changed and states are now tracking students and rewarding institutions based on six-year graduation rates rather than enrollment numbers (Lee \& Rawls, 2010).

For the United States to remain globally competitive, in both education and business, more students must be retained and graduated from colleges and universities across the nation. Kentucky is not unique in the challenges being faced (Evans, personal communication, February 21, 2011). The freshman to sophomore retention rate in Kentucky $(72 \%)$ is lower than the national rate (78\%). Of those who enter a Kentucky institution of higher education intent on earning a bachelor's degree, only $47.3 \%$ persist to graduation within six years or less (Lee \& Rawls, 2010). One goal of the Kentucky Postsecondary Education Improvement Act of 1997 (HB1) was to raise the Kentucky standard of living and quality of life to the national average by the year 2020 . To meet this goal, educational attainment of Kentucky citizens must increase, making retention of college students more important than ever. 
Kentucky has 26 in-state licensed independent institutions that are regionally accredited and nonprofit; 8 religious-based institutions that are nonprofit and independent; 5 institutions in the state licensed as for-profit; 16 two-year institutions comprising the Kentucky Community and Technical College System (KCTCS); and 8 state-supported four-year institutions (Kentucky Council on Postsecondary Education, 2011). No sweeping change can provide a magic answer for retention of students at so many diverse individual institutions.

The literature is replete with studies of student satisfaction (e.g., Guinn \& Mitchell, 1986; Hornbuckle, Mahoney, \& Borgard, 1979; McAnulty, O'Connor, \& Sklare, 1987; McLaughlin \& Starr, 1982; Stickle, 1982; Vowell \& Karst, 1987). Those studies generally indicate that students satisfied with their college experience are more likely to be retained and to graduate. Other studies related that students may base their satisfaction with the college experience on the services provided by their institution (Light, 2001; Tinto, 1993).

One service provided at each Kentucky institution is academic advisement. Though retention relates to many issues, the tie to academic advising is well documented in the literature (Bai \& Pan, 2009; Crockett, 1978; Habley, 1981; Light, 2001; Noel, 1978; Spady, 1971; Tinto, 1993). Light stated that "good advising may be the single most underestimated characteristic of a successful college experience" (p. 81).

\section{Academic Advising}

Various support services for college students are available including, for example, student financial assistance, tutoring, counseling, career services, and academic advising. Of particular relevance to this study is academic advising, since one barrier to student 
success may be whether students receive adequate or appropriate advising. To understand the role advising plays in retention, knowledge of its origins is important.

\section{History}

The value placed on education has long been a part of the fabric of America; however, academic advising did not become an integral part of higher education until the middle of the $20^{\text {th }}$ Century. In the earliest days of what is now the United States, the English colonists believed in the need to produce educated citizens and clergy. The main purpose of colleges was to help establish social order in communities, and the institutions provided a domestic means to educate privileged young men in civic responsibility. In the early schools, the faculty and students lived together; and the faculty supervised studies, the living environment, and even student worship (Frost, 2000).

In the late 1700 s the mission of higher education evolved from providing the lessons of civic responsibility to the church and state, to providing the education necessary to be a citizen in a new Republic, and institutions began educating women. Women first received a liberal education at academies and seminaries and in the late 1800s enrolled in colleges across the United States for practical education.

In the late 1800 s and early 1900 s, a chasm existed between faculty who wanted to perform research and administrators who believed "that faculty should give advice and assistance to students outside the classroom as well as inside" (Frost, 2000, p. 8). To lessen the chasm, universities attempted to pair students with faculty members as mentors/advisors and instituted the beginning of the system of academic advising, as we know it today. Johns Hopkins in 1889 instituted the practice of faculty members 
providing advice to students about their courses of study (Grites, 1979). By the late 1930s nearly all institutions had formalized advising programs (Raskin, 1979).

The end of World War II changed the face of higher education in the United States. The founding of the National Science Foundation created job opportunities for those trained in scientific and technological research (Frost, 2000). The passage of the G.I. Bill enabled World War II veterans to attend college tuition-free. With the increased need for trained scientists and the matriculation of military veterans, college and university enrollments dramatically increased. Tuttle (2000) stated, "The huge growth of enrollment after World War II spawned the plethora of student services common on campuses today" (p. 15).

In 1947 Alfred University's president charged a committee of faculty and others to create a program that would provide advisement specifically for freshmen and sophomores (Frost, 2000). The committee recommended the establishment of an office that would orient freshmen to the history and traditions of the university, to study methods, and to general conduct acceptable as a member of a university community. This system was among the first to supplement faculty in the advising process.

For several centuries colleges and universities had designed their programs of study without input from students. In the 1960s societal changes influenced institutional structures and roles. More people showed a greater interest in access to higher education and in solutions to immediate problems than in the traditional methods of the disciplines. During that time advisement focused on the dispensing of information about courses and class schedules and prescribed remedies for problems. 
Tuttle (2000) reported that throughout the 1970s and 1980s "tumbling enrollments and higher attrition, lack of faculty interest or rewards for advising, and student demands for improved advising" (p. 15) led many colleges and universities to establish advising centers and coordinate advising on campuses. Recognition of advising as a legitimate profession grew with the 1979 formation of the National Academic Advising Association (NACADA).

Frost (2000) credits NACADA with generating greater interest in the field of advising and in continued research designed to improve practice. Noel (1978), for example, related effective advisement programs to increased student retention. Habley and McClanahan (2004) noted that academic advising was among the top three programs "responsible for the greatest contribution to retention in four-year public colleges" (p. 6). Tinto (2004) stated that "effective advising is an essential part of successful retention programs" (p. 8) and, in a 2002 speech presented at the annual meeting of the American Association of Collegiate Registrars and Admissions Officers, he said:

... students are more likely to persist and graduate in settings that take advising seriously; that provide clear, consistent, and easily accessible information about institutional requirements, that help students understand the roadmap to completion, and help them understand how they use that roadmap to decide upon and achieve personal goals. (p. 2)

Academic advisement, then, serves as a means through which institutions can provide students somewhat individualized guidance and support to successfully navigate college. 


\section{Literature Summary}

Crookston (1994) coined the terms for the two (now) best-known and most often used approaches to academic advising - developmental and prescriptive. Developmental advising is based on advising as a form of teaching, with faculty advisors focusing on student development. In prescriptive advising the faculty-student relationship is based on authority, with the advisor prescribing a remedy and the student following the advice. The responsibility of the advisor ended with the dispensing of advice.

An era of research highlighting the benefits of developmental advising followed, and prescriptive advising was generally viewed as inappropriate. According to Ender (1994), “... developmental advising was advocated as a strategy to enrich and assist students as they made meaning of the collegiate experience" (p. 105). Fielstein (1994) posited that enthusiasm for developmental advising caused advisors and administrators to overlook "the value of certain traditional, prescriptive activities as prerequisites to developmental advising" (p. 77).

Pardee (1994) suggested that, though many advisors advocated developmental advising, prescriptive advising was more commonly practiced because of certain constraints - advisor load and a lack of training in how to administer developmental advising. Gardiner (1998) summed up the problem many advisors face in trying to institute developmental advising when he stated, "The busyness of daily routine and the seeming rightness of the familiar obscures [sic] the need to change" (p. 71).

The literature provides examples of students who prefer developmental advising and those who prefer prescriptive advising. Few studies, however, provide a definitive basis for whether advisement should be expressly one style or the other. Hale, Graham, 
and Johnson (2009) found that students strongly prefer developmental advising. Fielstein (1987) discovered that not all students prefer a developmental advising relationship; and Mottarella, Fritzsche, and Cerabino (2004) found that prior advising experiences related to preferred advising style. In their study, students who preferred developmental advising had a history of developmental advisement; whereas those who preferred prescriptive advising historically had received prescriptive advisement.

Students who understand the reason for advisement and whose expectations are met through that process may have a greater level of satisfaction than others. Higher levels of satisfaction have been significantly related to increased retention (Hornbuckle et al., 1979; McAnulty et al., 1987).

The importance of understanding how student expectations shape their college experiences is well documented in the literature (Light, 2001; Miller, Kuh, Paine, \& Associates, 2006; Miller, Binder, Schuh, \& Associates, 2005). Experiences provide the basis for expectations, and those related to college may come from a variety of sources, including parents or siblings who have attended college as well as the portrayal of college life in popular culture and the media. Student expectations may or may not be realistic. Faculty and administrators who have good information about their students' expectations can better design and implement programming to meet those expectations or help students revise them.

Research related to academic advising reveals that student expectations most often not met are those regarding the preferred style of advising. Ethnicity, race, age, gender, student classification, part-time or full-time student status, socioeconomic status, and first-generation status identify some of the differences among students on college 
campuses today. Students in each category may have different expectations of an advising system (Bai \& Pan, 2009; DeShields, Kara, \& Kaynak, 2005; Duggan \& Pickering, 2008; Friedman \& Mandel, 2009; Kiser \& Price, 2008; Pan, Guo, Alikonis, \& Bai, 2008; Spady, 1971; Vaquera \& Maestas, 2009; Wells, 2008).

The present study examined whether students and advisors at a public four-year university had equivalent perceptions of the intended role and outcomes of academic advising. Though style and delivery systems may vary across campus, it is important that both students and their advisors, whether faculty or professional staff, understand the purpose of advising. Whatever advisors perceive they have delivered ultimately is what students should perceive they have received.

\section{Research Questions}

1. Do students prefer developmental or prescriptive advising?

2. Do advisors prefer developmental or prescriptive advising?

3. Does student preference differ by college and/or department?

4. By college and/or department, do student and advisor preferences match?

5. Is there a relationship between certain student demographic variables (i.e., gender, age, classification, status, ethnicity, generational status) and student preference for advising style?

6. Is there a relationship between certain advisor demographic variables (i.e., age, gender, advisor type) and advisor preference for advising style?

\section{Significance of the Study}

Little empirical evidence exists that clearly defines the style of advising or the advisor type that most benefits students. Institutional faculty and staff could improve 
advising across campus by understanding the needs of their own population of students and advisors. Determining whether students find congruence between the advising they prefer and the advising they receive might result in changes that would benefit both students and advisors and help improve overall retention rates. 


\section{CHAPTER II}

\section{REVIEW OF THE LITERATURE}

Retention of students is a priority for institutions of higher education (Lee \& Rawls, 2010), and the link between academic advising and retention is strong (Bai \& Pan, 2009; Crockett, 1978; Habley, 1981; Light, 2001; Noel, 1978; Spady, 1971; Tinto, 1993). This chapter reviews literature concerning (a) academic advising, (b) advisors, (c) advisees, and (d) preference of advising style.

\section{Foundation}

Traditional advisement grew from the changes over centuries in institutions of higher education. With the advent of advising centers in the 1970s, the focus changed. O'Banion (1972/1994) and Crookston (1972/1994) wrote seminal articles arguing that developmental advisement best served the needs of students and stemmed from the belief that students came to a university in varying stages of development.

O'Banion (1972/1994) defined academic advising as a service designed to help students choose a course of study that would help develop total potential. Included in advising responsibilities were the exploration of life and vocational goals, exploration of program and course choices, and, finally, scheduling classes. He indicated that prescriptive advising began with the exploration of majors and that developmental advising began with the exploration of life goals between advisor and student. 
Similarly, Crookston (1972/1994) described the historic focus of the advisor as concerned with major or occupation choice where advisors prescribed a course of action they expected students to follow. He referred to developmental advising tasks as experiences that contributed to development and aided in successful change.

Prescriptive advisors, according to Crookston (1972/1994), focus on student limitations, believe students are lazy and need prodding, and think they seek only extrinsic rewards (i.e., grades, credit, and income). Advisors view students as immature and irresponsible people who require close supervision. They are responsible for providing the information students need to fulfill the requirements of their degree; any relationship beyond that is the responsibility of the student. Prescriptive advisors enforce standards and regulations, and students have little input into decisions regarding their collegiate career. The advisor is the authority figure, and a low level of trust exists in the relationship.

Developmental advisors (Crookston, 1972/1994) focus on student potential and believe students are learning and developing as they try to reach their goals. They believe students are motivated by both intrinsic (achievement, mastery) and extrinsic (status, recognition) rewards (Crookston, 1994); are in the process of growing and maturing; and are capable of self-direction. In the developmental relationship the student and the advisor work together to initiate contact and make task-related decisions. Both parties share responsibility for outcomes and together evaluate student progress. The relationship grows from mutual respect and trust that builds over time.

Ender, Winston, and Miller (1982) also defined developmental advising relationships as "life goal and personal growth oriented" (p. 8) and iterated that: 
Developmental advising both stimulates and supports students in their quest for an enriched quality of life; it is a systematic process based on a close student-advisor relationship intended to aid students in achieving education and personal goals through the utilization of the full range of institutional and community resources. (p. 8)

The following section will identify the theories that provide the foundation for developmental advising.

\section{Cognitive- and Psychosocial-Developmental Theories}

\section{Cognitive-developmental Theories}

Cognitive-developmental theories seek to understand structural (cognitive) growth and help explain how people think. According to cognitive-developmental theories, individuals sequentially pass through certain stages of cognitive structure that help them organize how they perceive their experiences and reason through the stages. As individuals make meaning of events in their lives and work through changes, development occurs (Creamer \& Associates, 1990).

Piaget's work provided the foundation for some theories of cognitivedevelopmental growth (as cited in Creamer, 2000). Piaget believed that humans progressed through stages of development beginning at birth with the formation of "sensorimotor intelligence" (Piaget, 1972/2008, p. 41) in which infants use inborn skills such as looking, sucking, grasping, and listening to learn about their environment. Passage through the various stages of development from birth to about 12 years of age

occurs slowly overall. Some pass quickly through certain stages and others more slowly, but all people pass through the same stages and in the same order. Development 
continues, but at a faster pace, during the pre-adolescence period (12-15 years) and into adulthood as logical thought, deductive reasoning, and systematic planning solidify over time (Creamer, 2000).

Kohlberg (1964) focused on the moral development of individuals that resulted in the development of character. He defined moral character as "the sum total of a set of virtues ... subject to the moral sanctions of society" (p. 395). Kohlberg believed that moral character developed through six stages ranging from obeying rules to avoid punishment through obeying rules to avoid self-condemnation. According to the theory, passage through the stages occurs over time. Individuals may pass through stages more quickly or more slowly. However, similar to Piaget's theory, Kohlberg thought they must pass through one stage to sequentially move on to the next.

Perry's (1968) theory of intellectual and ethical development focused on traditional age college students and identified cognitive stages through which he believed all students passed. All relate to student beliefs regarding who should provide knowledge. Perry's theory included nine stages in which students experience cognitive dissonance that push them to the next stage of development.

Rest (1979) viewed Kohlberg's theory as a conceptualization of how people cooperate and applied it to college students. Each stage of moral development allows a student to learn different ways to cooperate and reasons for doing so. Rest believed cognitive development was not purely passage through one stage at a time. Instead, he posited that students could have mastery in some stages and still be learning in others. $\mathrm{He}$ described his theory as "a much messier and more complicated picture of development" (1979, p. 65). 


\section{Psychosocial-developmental Theories}

Psychosocial-developmental theories emphasize holistic development as people systematically pass through various stages/phases in life. As individuals grow toward adulthood, they make conscious adjustments based on social influences. Two of the bestknown psychosocial-developmental theories came from Erikson (1959) and Chickering (1969).

Erikson's (1959) theory of development grew from Freud's concept of ego identity and suggested that individuals pass through eight stages. Each stage comprises a series of crises; as the person works through the crises, he or she grows and develops. Erikson believed that development comes from a combination of genetic and environmental influences. Similar to Piaget, Erikson proposed that the rate at which people pass through the stages could be different for each. Erikson's theory covered the entire life-cycle.

Chickering (1970) focused on a key middle stage of development from Erikson's (1959) theory: the adolescent identity crisis. He focused on adolescent development because most college students in the early 1970s were adolescents (Torres, 2009).

Chickering (1970) proposed seven vectors relevant to college student development and believed that students could be in multiple vectors at one time. The seven vectors were (a) developing competence, (b) managing emotions, (c) moving through autonomy toward independence, (d) developing mature interpersonal relationships, (e) establishing identity, (f) developing purpose, and (g) developing integrity. Chickering posited that students who successfully develop competencies learn to manage social situations. Managing emotions includes becoming aware of and learning to express one's feelings. A lack of success may result in difficulties in mastering further 
vectors. Moreover, Chickering proposed that students develop autonomy by learning to trust in their own abilities and feelings. They first establish emotional autonomy and then attain instrumental autonomy where they can make and carry out plans to reach goals.

\section{Conclusion}

Cognitive- and psychosocial-developmental theories provide advisors a cognitive structure for understanding by which they can assess how students make sense of the experiences they encounter in college. According to Ender (1994), “... primarily, developmental advising was advocated as a strategy to enrich and assist students as they made meaning of the collegiate experience" (p. 105). Linking the concept of advisement to student development theory strengthens the view of advising as a form of teaching (Broadbridge, 1996) that encourages students to develop their thinking skills (Thomas \& Chickering, 1984) and to address both long- and short-term goals (Frost, 1991).

\section{Academic Advising}

The academic advising process is complex. Institutional structures define how advisement will be offered, who will deliver the advising, whether and what kind of training advisors will receive, and what style of advising will be offered to students.

\section{Organizational Models}

Habley (1997) described seven organizational models of academic advisement based on data collected from the administration of the fifth ACT national survey on advising practices. A mixture of two-year public, two-year private, four-year public, and four-year private institutions $(N=754)$ responded to the survey.

Analysis of the results of the study revealed that institutional type (public or private) and size affected model choice. Faculty only and supplementary models (i.e., an 
advising office provides general academic information for students and faculty have responsibility for approving student transactions) were in use in most private institutions ( $71 \%$ of two-year and $72 \%$ of four-year) and in schools with fewer than 1,000 students. When enrollments passed 20,000 , only $9 \%$ of campuses reported using faculty only or supplementary models.

Large institutions reported the use of split (35\%), self-contained (26\%), and satellite (23\%) models. Split models offer a centralized advising office dedicated to specific groups of students (i.e., generally undeclared or underprepared students), while other students (i.e., those with declared majors) receive advising in departmental offices or other academic units. Self-contained models provide advisement for all students from enrollment to departure in a centralized office. In the satellite model advising is established by, and takes place in, each school, college, or division. Habley (1997) posited that a more decentralized administration due to institutional size provided various campus entities a choice in the type of delivery model used.

Habley (2004) examined the results of the sixth ACT national survey on academic advising and related that, as institutions became more diverse, the variety of advising practices increased. He voiced concern that individual advisors would adopt successful ideas, concepts, and strategies from other institutions without adapting them to their own campuses. He warned that no one strategy would be successful across all institutions. Instead, he cautioned that “. . . all facets of advising must be examined within the framework of the institutional mission and the needs of the students it serves" (p. 95). 


\section{Roles and Responsibilities}

O'Banion (1972/1994) acknowledged widespread agreement about the importance of academic advising and "little agreement regarding the nature of academic advising and who should perform the function" (p. 62). The literature provides scattered listings of advisor roles and responsibilities and no concise checklist appropriate for every college or university.

The amount of time advisors spend providing direct service advisement relates to advisor type. For example, the results of the Lynch and Stucky (2000) study revealed that faculty advisors spent approximately $24 \%$ of their time on advising activities and $75 \%$ on other institutional responsibilities (i.e., teaching, research, committee service, or community service). Professional advisors reported spending about $80 \%$ of their time on advising activities, including $60 \%$ in direct service advising. The professional advisors spent the remainder of their time on other institutional responsibilities.

Broad areas related to advisor responsibility included involvement in advising research, career/life planning, mentoring, new student orientations, personal counseling, course selection and registration, and advising special student populations (Lowe \& Toney, 2000; Lynch \& Stucky, 2000). Advisors were expected to possess knowledge of the institution's policies and procedures, to know when and where to make student referrals, to keep good records of advisement meetings, and to have a good understanding of general education requirements; these components are viewed as important to successful advisor-student interactions (Afshar \& O'Hara, 2006; Beasley-Fielstein, 1986; Dillon \& Fisher, 2000; Lowe \& Toney, 2000; Lynch \& Stucky, 2000). 
In an effort to understand what students and advisors believed were important advisor responsibilities, Lowe and Toney (2000) gathered the opinions of advisors and students. Participants in the study included undergraduate and postbaccalaureate/graduate students $(n=200)$, professional advisors $(n=6)$, and faculty advisors $(n=5)$.

Student respondents identified important advisor responsibilities as providing orientation to campus life, assisting in identifying learning styles, providing correct information, establishing a caring relationship, helping to clarify career goals, and informing students of scholarships and internships. Important advising responsibilities identified by advisors in the Lowe and Toney (2000) study included making acrosscampus referrals where appropriate, establishing caring relationships, understanding the needs of both traditional and non-traditional students, helping students orient to campus life, clarifying educational goals, and helping students to establish personal goals. They also reported that advisors should help students identify academic problems.

\section{Advisor Type}

Faculty and professional advisor responsibilities greatly differ among institutions. Advising may become an additional duty for faculty members. Professional advisors may become involved in committee service or research as an additional duty. Advisors may provide centralized advising services for a university, for specific departments, or centralized for colleges. The research provides no definitive findings that faculty advisors or professional advisors are the best option for students in every situation.

Faculty advisors. Faculty members in universities and colleges play many roles including teacher, committee member, researcher, colleague, and academic advisor. 
Discipline-specific knowledge is a major strength of faculty advisors (Crockett, 1985) that enables them to provide students with course specific information, helps them tie courses to program requirements, and gives them knowledge about career opportunities in their field (Larsen \& Brown, 1983).

Advisement often receives the least attention as new faculty members learn their new roles in a department. Waters (2002) examined the socialization process, the information needs of new faculty advisors, and what types of information are provided. The seven information types include (a) technical, (b) referent, (c) social, (d) appraisal, (e) normative, (f) organizational, and (g) political.

Technical information relates to the execution of tasks. Referent information provides the requirements and expectations of the role. Social information explains relationships in an individual's new area. Appraisal information provides the metric against which one will be evaluated (performance and behavior). Normative information defines the organization's culture. Organizational information relates to structure and procedures as well as associated products and services. Political information relates the power structure within the organization.

Faculty members $(N=221)$ from four colleges participated in the study. Each college utilized a faculty-based advising system. Respondents reported receiving more organizational information than any other type and rated the information as most useful. They received less appraisal information than any other type and rated it least useful. Faculty advisors reported receiving the most advising-related information from sources other than colleagues, deans, or department chairs. The findings from the study indicated 
that faculty advisors did not receive adequate information about advisement or how it related to annual appraisals.

A review of the literature revealed that faculty advisors perceived their training to become advisors as inadequate. For example, Swanson (2006) evaluated the training available to faculty advisors. Participants $(N=103)$ in the study were faculty $(n=89)$ and administrators $(n=14)$. An analysis of the findings revealed that more than half of the respondents indicated few opportunities to take part in training for academic advising. Twenty-three percent $(23 \%)$ of respondents indicated that some training was provided. Only $8 \%$ indicated that training was always available.

Faculty members undergo evaluations for promotion and tenure. An examination of the literature showed that sometimes advisement does not play a role in the process. Dillon and Fisher (2000) examined advisor perspectives on how advising affected or benefited faculty members; the factors contributing to, or detracting from, successful advisor-student interactions; and what could be done to improve faculty advisement.

Respondents $(N=50)$ reported that, though the administration claimed good advisement affected student retention, faculty did not believe advising related to promotion and tenure considerations. Most respondents $(91 \%)$ believed the load and responsibilities of advising should become part of promotion and tenure considerations, primarily because effective advising takes time away from teaching, research, and other services considered in promotion decisions.

The value placed on advising in the promotion/tenure evaluation process can produce negative effects for faculty who provide exceptional advising. For example, participants in the Dillon and Fisher (2000) study indicated that earning the reputation of 
being a good advisor also could negatively affect a faculty member by resulting in an uneven distribution of students among faculty advisors. In another study, Shields and Gillard (2002) researched how faculty advisors interpreted their advising role, what training and/or guidance they received, what they perceived as the administrative expectations of advisors, and whether they received recognition or rewards for their roles as advisors.

An analysis of the data indicated that differences existed between the perspectives of administrators and faculty advisors regarding advising responsibilities. Administrators believed effective advisement played a role in the recruitment and retention of students and in student satisfaction. Faculty members perceived student advising as a timeconsuming task with little or no recognition or reward.

Although the respondents to the Shields and Gillard (2002) study perceived advising responsibilities and obligations as personally rewarding in many ways, they indicated that advisement also generated frustration when obligations were unclear. Respondents reported insufficient resources related to advising obligations and little or no reward or recognition for advisement. Advising was not listed as a specific tenure-track expectation, and few advisors received training.

Allen and Smith (2008) used a one-way within-subjects ANOVA to assess how advising was valued and by whom. The results of the data analysis indicated that faculty perceived differences in the value placed on advising of undergraduates by various groups, $F(2.65,395.35)=54.84, p=.000$. Department chairs were perceived to value advising the most, followed by departmental colleagues. Deans were perceived to value 
academic advisement less than departmental colleagues, and senior administrators were perceived to value it the least of all.

Faculty rated all functions as important but discriminated among them regarding responsibility levels. For example, faculty agreed that providing accurate information about degree requirements was the most important type of advising students receive, but it was not one of the two functions for which they felt the most responsibility. They also rated the provision of information about how things work at the university as important, but it received one of the lowest responsibility ratings. Allen and Smith (2008) posited that faculty focusing on their own disciplines could indicate they believed someone else at the institution should provide the basic university information.

Conclusion. A review of the literature revealed that faculty advisors may not receive the information (Waters, 2002) or training (Swanson, 2006) needed to make them effective advisors. They may not believe that the advising time they spend benefits them in promotion or tenure considerations (Allen \& Smith, 2008; Biggs, Brodie, \& Barnhart, 1975; Dillon \& Fisher, 2000; Severy et al., 1996; Shields \& Gillard, 2002); and they may believe that being a good advisor could negatively affect those considerations. Faculty advisors also may not receive recognition or reward for their role (Shields \& Gillard, 2002). Despite the barriers, however, faculty advisors still provide most of the advisement in American colleges and universities (Habley, 2004). The time they spend advising decreases as the time they spend on other roles increases (Milem, Berger, \& Dey, 2000).

Professional advisors. The academic advisor role for professional advisors includes career/life planning, personal counseling, and assisting students with course 
selection and registration. Other duties include involvement in research, submissions to advising publications, and new student orientations. In fact, Lynch and Stucky (2000) reported that professional advisors spent greater amounts of time in those three areas than did faculty advisors. The advisors in the study also reported greater involvement in advising special populations than faculty advisors. Special populations included student athletes, students with disabilities, first-year students, international students, transfer students, undeclared and underprepared students, and underrepresented student populations. Professional advisor respondents also reported spending more time working with students on probation, dismissal, and reinstatement decisions and advising than did faculty advisors.

Faculty members typically were hired for their level of education and disciplinespecific knowledge and not necessarily to provide advising to students. King (1993) related that professional advisors, however, were most commonly hired based on "their interest in and ability to work with students" (p. 51). When they had a reasonable advisee load, they could be more accessible than faculty advisors and may have had more time for personal interactions with students.

Conclusion. Though both faculty advisors and professional advisors have strengths and challenges related to academic advisement, research findings do not support either group as optimal for all students in all institutions and in all situations. Faculty advisors can provide advisees a connection to their major based on discipline-specific knowledge. Professional advisors may have more time to share with students than faculty advisors. Understanding student preferences relative to advisor type might help an 
institution put in place the optimal advising system for its particular needs and demographics.

Student preference for faculty or professional advisor. Habley (1994) examined student perceptions of the quality of academic advisement. The research question guiding the study queried whether students perceived a difference in advising received from faculty advisors as opposed to that received from other advisor types. The sample was comprised of 58,696 student records obtained from 110 colleges and universities that administered the Survey of Academic Advising over a period of 4 years and 10 months. Of the students, 42,423 reported having a faculty advisor, 8,087 reported meeting with a professional advisor, and the remainder reported meeting with an "other" advisor or not having an assigned advisor.

An analysis of the data indicated that students with faculty advisors reported discussing different things than did students who worked with professional advisors. More students reportedly discussed academic progress, scheduling and registration procedures, dropping/adding courses, meeting requirements, finding a job after college, and continuing their education after college with faculty advisors than with professional advisors. Habley (1994) indicated that discussions with professional advisors included issues such as major changes, improving study skills, obtaining remedial assistance, obtaining financial aid, and withdrawing/transferring schools. Comparisons of means and standard deviations of scores related to satisfaction with assistance received provided no evidence that students were more (or less) satisfied with faculty advisor assistance than with that provided by professional advisors. 
Belcheir (1998) examined student satisfaction with advising based on who (faculty or professional advisor) advised the student and reported that differences in satisfaction existed depending on the student's advisor $(R M S=40.02, d f=4, p=.001)$. Students most satisfied with the advising system indicated advising center staff as their advisor, followed by faculty.

Lynch (2004) examined advisee utilization and evaluation of academic advisement provided by three delivery methods: (a) professional advisors in advising centers, (b) professional advisors in academic departments, (c) and faculty advisors. The study took place at a public, research, land-grant University whose enrollment of undergraduates was distributed over seven colleges.

An online advising survey was made available to each returning student in the fall semesters of 2001 and 2002. Undergraduates $(N=28,895)$ completed the surveys as they accessed the university's enrollment/registration system. Analysis of the data from the Lynch (2004) study indicated that $90 \%$ of the students consulted with advisors. Advising centers had the lowest rate of utilization. Students advised by faculty reported a $91 \%$ utilization rate; students advised by departmental advisors reported a rate of $97 \%$.

Professional advisors in both advising centers and departments received higher ratings than did faculty members on level of knowledge of degree/program requirements and policies and procedures. Professional advisors also received higher ratings on willingness to consider past academic performance, to discuss long-term plans, and to help with or refer for personal/non-academic issues. Students advised by professional advisors also expressed higher levels of satisfaction with their advisement and advisor than did those advised by faculty members. 
Conclusion. A preponderance of the research on academic advisement over the decades since the O'Banion (1972/1994) article focused on student preference of faculty advisors versus professional advisors. Based on evidence found in the literature, it is not possible to support a conclusion that either faculty advisors or professional advisors provide the best option for institutions of higher education.

\section{Advising Style}

Winston and Sandor (1984a) reported that, at the time of their study, the literature provided no operational definition of developmental academic advising. Using the developmental advising concept provided by Crookston (1972) and the Ender, Winston, and Miller (1982) definition of developmental academic advising, Winston and Sandor (1984b) created the Academic Advising Inventory (AAI). The purpose of the AAI was to provide a tool through which academic advising programs could be evaluated.

The AAI was to be used to determine whether students, based on the advising they received, preferred one style (developmental or prescriptive) over the other. Participants in their study included undergraduates $(N=306)$ from the University of Georgia, representing 10 schools and colleges in the university and 17 major areas.

Each statement on the AAI lies on a continuum, with one end indicating prescriptive advising (scores from 14-56) and the other end developmental advising (scores from 57-112). The continuum allows interpretation of more and less prescriptive advising and of less and more developmental advising. For example, an advisor scoring 55 on the continuum is still considered a prescriptive advisor but may also have some developmental traits as recognized by students. Advisors with a score of 20 , though, have been rated as formal and distant in their dealings with students. 
Students selected the statement most consistent with their advising preference and then rated the importance of each aspect on a Likert-type scale where 1 (very important) to 4 (slightly important) indicated a preference for prescriptive advising and 5 (slightly important) to 8 (very important) indicated a preference for developmental advising. Figure 1 provides an example for clarification.

Figure1

Sample Question - Academic Advising Inventory Advisor tells student what he/she Advisor helps student learn about needs to know about programs and OR courses and programs for self. courses.

\begin{tabular}{|c|c|c|c|c|c|c|c|}
\hline $\begin{array}{l}1 \\
\text { Very } \\
\text { important }\end{array}$ & 2 & 3 & $\begin{array}{l}\quad 4 \\
\text { Slightly } \\
\text { Important }\end{array}$ & \begin{tabular}{l}
\multicolumn{1}{c}{5} \\
Slightly \\
important
\end{tabular} & 6 & 7 & $\begin{array}{l}\quad 8 \\
\text { Very } \\
\text { important }\end{array}$ \\
\hline
\end{tabular}

Source: Winston \& Sandor, 1984b

Respondents preferred developmental advising on 21 out of 22 items. The one prescriptive item preferred by students indicated a desire for advisors to use their knowledge of college policies to inform the student on what to do rather than tell the student where to learn about the policies on their own. Results from the Winston and Sandor (1984a) study revealed that students preferred the developmental descriptions on the AAI.

One facet of developmental advising relates to how personal the relationship becomes between student and advisor. Fielstein (1987) sought to clarify the type of relationship students wanted when interacting with a faculty advisor. The research question guiding the study asked whether the personal relationship described in developmental advising was the actual relationship desired by students.

An analysis of the results indicated that most students believed it important for their advisor to be personally acquainted with them. However, nearly $20 \%$ of students did 
not rate personal acquaintance as a priority. Fielstein (1987) posited that offering only developmental advisement could be detrimental to those students who perceived "the role of the advisor ... to be that of an information-giver who provides accurate and timely information" (p. 39).

Using the same data gathered for her 1987 study, Fielstein (1989) examined whether students preferred prescriptive or developmental advisor activities. The initial survey instrument included 30 activities used in previously developed instruments of student perceptions of advisement (Grites, 1981; Trombley, 1984; Winston \& Sandor, 1984b). It included questionnaires used by other higher education institutions and from interviews she undertook with advisors from her own institution's three colleges. A pilot study was administered to ensure clarity of wording and presentation of items.

A list of 20 activities made up the final questionnaire. The researcher and three additional faculty members independently rated the 20 items to determine whether an advising activity could be categorized as either developmental or prescriptive. Of the 20 items, 11 were identified as developmental and 9 as prescriptive. Respondents rated each activity as a high priority, a priority, or not a priority.

The mean priority rating of prescriptive advising activities $(\chi=2.47, S D=.31)$ was higher than that of developmental advising activities $(\chi=1.82, S D=.36)$; and a onetailed paired t-test revealed a significant difference between the ratings $(t(1,88)=18.33$, $p<.001)$. Students perceived prescriptive activities as a higher priority than developmental activities.

Prescriptive activities rated by at least half the students as a "high priority" indicated the need for advisors to possess technical expertise. Of the developmental 
activities, more than half the students indicated as a "high priority" only one item keeping regular office hours and being accessible (63.3\%).

An analysis of the findings of the Fielstein (1989) study supported a combination of prescriptive and developmental advising activities. While students desired a trusting and caring relationship, they did not want their advisors to delve too deeply into their personal lives. Students wanted their advisors to have a high level of technical expertise and to be easily accessible. They wanted their advisors to be open to the idea of helping with personal issues but did not want their advisors to initiate that involvement.

Conclusion. Habley (2004) assessed responses to the sixth national ACT survey of academic advising and noted that, although advisors made incremental gains in the achievement of the eight advising goals since 1983, only one goal (providing accurate information to students) moved above the satisfactory (4.0) level. Ratings on the remaining seven goals fell between neutral and satisfactory. The three goals with the lowest ratings related directly to developmental advisement and included (highest rating to lowest) (a) assisting students in considering life goals by relating interests, skills, abilities, and values to careers, the world of work, and the nature and purpose of higher education; (b) assisting students in self-understanding and self-acceptance; and (c) assisting students in developing decision-making skills (Habley, 2004).

A review of the literature revealed that students do not always prefer one particular style of advising (Beasley-Fielstein, 1986; Fielstein, 1989; Saving \& Keim, 1998). In fact, Weir, Dickman, and Fuqua (2005) argued that both forms of advising could be necessary components of advisement sessions over time and that "they could be complimentary [sic] rather than mutually exclusive" (p. 75). Smith and Allen (2006) 
stated that effective advising likely includes both developmental and prescriptive attributes. An analysis of the data from a pilot study on their campus indicated that graduating students rated the advisor's ability to give accurate information about degree requirements as more important than other developmental advising functions.

\section{Congruence between Advising Style Received and Preferred by Students}

The literature review provided findings indicating that some students prefer developmental advising and others prefer prescriptive advising. This section examines whether students experience congruence between the style of advising preferred and the style received.

Alexitch (1997) examined the relationship between satisfaction with advising received and students' preferred style and content of advising. Participants in the survey study included undergraduates $(N=81)$ from a mid-sized Canadian university. Alexitch (1997) used a modified version of the Academic Advising Inventory (AAI) developed by Winston and Sandor (1984b).

Results from a paired $t$-test revealed that students' ratings of their preferred advising style $(M=87.36, S D=13.32)$ were significantly higher than the ratings of the advising style experienced $(M=59.19, S D=13.56)$. Students preferred a more developmental advising style than they received $(t(80)=-14.08, p<.001)$.

Hale et al. (2009) explored whether congruence existed between student perceptions of academic advising style received and their preferred advising style. A secondary purpose was to determine whether possible differences between received style and preferred style were related to satisfaction ratings. Participants in the study included undergraduates $(N=429)$ from one college at a mid-south doctoral university. The 
Academic Advising Inventory (AAI; Winston \& Sandor, 1984b) was the survey instrument used.

Hale et al. (2009) reported that results of a $t$-test for unequal variances revealed the mean scores on Part IV of the AAI were significantly different between preferences for prescriptive and developmental advisors, $t(33 \mathrm{~A})-25.26 ; p<.0001$; Cohen's $d=2.43$. Grouping students by current and preferred advising styles resulted in $79.7 \%$ of students reporting congruence between advising received and their preferred advising style. Only about $2 \%$ of students $(1.8 \%)$ who preferred prescriptive advising believed they received that style. The rest of the students reported receiving and preferring developmental advisement.

Approximately $20 \%$ of students reported a lack of congruence between preferred and received advising styles. Of those, $90.0 \%$ had prescriptive advisors but preferred developmental advising. A lack of congruence, however, did not necessarily result in dissatisfaction with advising. Hale et al. (2009) noted that, overall, respondents were satisfied with the advising they received and reported the mean level of student satisfaction with advising as $3.02(\mathrm{SD}=0.71)$ on a 4-point Likert-type scale $(1=$ low satisfaction and $4=$ high satisfaction).

A one-way analysis of variance (ANOVA) indicated a significant difference in satisfaction with advisement when students were grouped by current advisor's style and preferred advising style $\left(F(3,226)=22.47 ; p<.0001 ; \mathrm{R}^{2}=.17\right)$. Post-hoc analysis revealed that students who received and preferred developmental advising had a significantly higher level of satisfaction than students with a prescriptive advisor who preferred developmental advising. The mean satisfaction scores for students who 
experienced congruence between received and preferred styles were significantly higher $(M=3.20 ; S D=0.65)$ than those experiencing incongruence $(M=2.52 ; S D=0.60$; $t(109)=8.07 ; p<.0001)$.

To understand how students rated satisfaction with advising, Mottarella et al. (2004) investigated student preferences (dependent variable) across five advising dimensions including advising style. The quantitative study used policy capturing to examine variables contributing to student satisfaction with advising. The policy capturing method allowed researchers to use multiple regressions to model how people weigh and combine information to make a judgment. They applied the method to judgments of 48 student advising scenarios.

Mottarella et al. (2004) used three parts of the Academic Advising Inventory (AAI; Winston \& Sandor, 1984b) in the study. Part one assessed student advising experiences on the prescriptive-developmental continuum, part two assessed advisoradvisee activities, and part three measured satisfaction with advising experiences. Demographic information was gathered on a form created in-house.

The sample included students $(N=468)$ enrolled in undergraduate psychology courses at a large southeastern university. All participants completed the study in 90 minutes or less in either their general psychology classrooms or within a psychology lab. They first completed the policy capturing, followed by the demographic form, and then the AAI.

For each of 48 scenarios, participants indicated a level of satisfaction ranging from 1 (extremely dissatisfied) to 7 (extremely satisfied). Mottarella et al. (2004) reported that, based on an $R^{2}=0.50$ criterion, policies were captured for 180 out of 468 
participants - a return of $39 \%$. For those participants, approximately $70 \%$ of the variance in satisfaction with advising was explained. Only those participants with captured policies were used in the final analyses.

Mottarella et al. (2004) examined the relative weights of cues across participants by averaging satisfaction scores for each profile and then regressing the data onto the cues. They reported that the regressions removed individual differences in judgments from the error term: $R^{2}=0.98 ; F(6,41)=377.90, p<0.0000$. All beta weights were statistically significant. Depth of the advisement relationship was the most important cue for all participants $(\beta=.77)$, and the least important cue was advisor gender $(\beta=.10)$. The second least important cue was advising style $(\beta=-.12)$. Most participants indicated a preference for prescriptive advisement.

Two differences were found for participants grouped by prior advising experiences. One difference was found on the Personalizing Education subscale. Students who received more prescriptive experiences preferred the prescriptive advising scenarios (mean $\beta=-.13 ; S D=.41$ ). Students receiving more developmental advising experiences preferred the developmental scenarios (mean $\beta=.06 ; S D=.37), F(1,140)=8.373, p=$ 0.004). The second difference was found among responses to the Class Scheduling subscale. Students who reported receiving more advising related to registration and class scheduling preferred non-faculty advisors over faculty advisors (mean $\beta=-.16 ; S D=$ $.21)$.

Conclusion. Though Crookston (1972/1994) and O'Banion (1972/1994) advocated developmental advising as providing the best outcomes for students, a review of the literature revealed that both developmental and prescriptive advisement are offered 
in colleges and universities across the nation. However, the style of advising students prefer may not be the style they receive (Alexitch, 1997). Hale et al. (2009) suggested that congruence between advising style received versus preferred could influence student ratings of satisfaction. Mottarella et al. (2004) indicated that student preference for advising style related to multiple variables, and offering only one style of advisement is not in the best interest of students.

\section{Student Demographics}

Student demographics have been examined relative to retention, preference for advisor type and advising style, and overall satisfaction with advising. This section will explore the various studies that investigated student demographics in relation to advising style preference and satisfaction with advisement.

In one of the first attempts to relate a preference for developmental or prescriptive advising to student characteristics, Crockett and Crawford (1989) used the AAI with the Myers-Briggs Type Inventory (Briggs \& Myers, 1983) to tie personality to advising style preference. The Myers-Briggs Type Inventory (MBTI) is comprised of four scales designed to describe how one interacts with the world (Myers \& McCaulley, 1985).

Along with personality, Crockett and Crawford (1989) examined preference by English course placement and by gender. They found that, overall, most respondents preferred developmental advising and that personality sometimes appeared to be related to student preference for advising style. For example, in regard to the Personalizing Education subscale, the sensing-intuition $(\mathrm{SN})$ scale was a significant predictor $\left(R^{2}=\right.$ $.030, p<.05)$. On the Scheduling Classes subscale, both sensing-intuition (SN) and thinking-feeling (TF) were significant predictors $\left(R^{2}=.081, p<.01\right.$ and $p<.05$, 
respectively). In addition, placement in regular English courses (versus developmental) and being female significantly predicted $\left(R^{2}=.070, p<.05\right.$, and $\mathrm{p}<.01$, respectively) a preference for developmental advising.

The results of the Crockett and Crawford (1989) study provided support for the AAI as a predictive/assessment tool. An analysis of the results also supported different variables such as personality, gender, or college readiness levels as predictive of preference for developmental or prescriptive advisement.

The purpose of the Fielstein, Scoles, and Webb (1992) study was to determine whether advising preferences were unique to certain student groups. Participants $(N=$ $103)$ in the survey study were both graduate/non-traditional $(n=21)$ and undergraduate/traditional $(n=82)$ students from a state university in the southern Midwest. The survey instrument was developed from previously published instruments (Fielstein, 1989; Grites, 1981; Kapraun \& Coldren, 1980; Trombley, 1984; Winston \& Sandor, 1984b); advising questionnaires from other institutions; and informal discussions with in-house advisors and advisees. Responses were on a 5-point Likert-type scale. Respondents read and responded to each of 34 questions two separate times, first to rate importance and then to rate how descriptive the item was to their own advisor interactions. Importance responses ranged from 1 (extremely unimportant) to 5 (extremely important), and descriptive responses ranged from 1 (not descriptive) to 5 (extremely descriptive).

An analysis of the results of the Fielstein et al. (1992) study revealed that respondents rated prescriptive items higher than developmental items both in terms of perceived importance and what they received in advising meetings. All students reported 
less satisfaction with developmental advising activities than prescriptive advisement activities. The difference between developmental and prescriptive items was slightly greater for non-traditional students. Traditional students were less satisfied with advising than non-traditional students; however, the mean rating for the group was 3.288 on a 5point Likert-type scale, indicating overall satisfaction by all students.

Smith and Allen (2006) examined student gender, age/cohort, financial need, and ethnicity as the predominant characteristics uniquely associated with importance ratings related to 12 advisement functions identified in their study. They found that gender was a significant predictor in 11 of the 12 functions. Smith and Allen reported only on those variables that reached significance at the $p<.05, p<.01$, or $p<.001$ levels. The greatest difference was found in referrals for nonacademic problems (for males, $M=4.04, S D=$ 1.74; for females, $M=4.60, S D=1.59$ ). They reported other characteristics significantly predictive of advising functions as ethnicity, financial need, and age/cohort but did not present specific significance levels.

The characteristics uniquely associated with satisfaction ratings were age/cohort, enrollment status, and ethnicity. Two characteristics significantly predicted more than one-half the advising functions. Smith and Allen (2006) reported that age/cohort significantly predicted 10 of the 12 advisement functions, and enrollment status significantly predicted 8 of the 12 . Significance values were not separately reported in the study.

The purpose of the Afshar and O'Hara (2006) study was to examine whether a relationship existed between certain advisor characteristics/responsibilities (characteristics) and student traits. In the event a relationship was found, they examined 
whether it had an impact on student satisfaction with the advising process. Personal and cultural traits included gender, class, ethnicity, GPA, age, and school.

The survey study provided 29 characteristics of advisors and asked respondents to rate the importance of each characteristic on a 5-point Likert-type scale. The characteristics "were those most often cited in the literature as critical for an effective academic advisor" (Afshar \& O'Hara, 2006, p. 27). The sample for the study included undergraduates $(N=222)$ from an urban private university.

An analysis of the results of the Afshar and O'Hara (2006) study revealed a consistent relationship between the 29 advisor characteristics and student traits. Their findings confirmed those of previous studies that identified the 29 characteristics as important to students.

Chi-square testing was undertaken to compare importance ratings of advisor characteristics to student traits. The tests revealed that student gender differences existed at the very important level, where females' responses to all but two questions were significantly different from those of males $(p<.05)$.

For the remaining student personal or cultural traits, Afshar and O'Hara (2006) first ranked the top 10 advisor characteristics identified as very important by the students and then performed Chi-square analyses to determine whether significant differences existed. An analysis of the findings revealed differences in each trait category. For example, an examination of class status (freshman, sophomore, junior, senior) revealed that sophomores and juniors had similar ratings, as did juniors and seniors. Differences between freshmen and senior responses indicated that students perceived advising needs differently over their academic career. 
Afshar and O'Hara (2006) compared nine pairs of ethnicity observations and concluded that ethnicity influenced student perceptions of advisors. They compared GPA in four categories and also found differences, with the most prominent between the lowest and highest GPA categories. Students with the lowest GPAs rated having an advisor willing to discuss personal problems as important and those with the highest GPAs preferred a friendly advisor. Conversely, a comparison of student ages revealed that younger students preferred a friendly advisor, while the older students preferred an advisor willing to discuss problems.

Afshar and O'Hara (2006) also made a comparison between respondents' schools. The top rated advisor characteristic was different among the three schools. Students from the School of Architecture and Design rated having an advisor who made appropriate referrals as most important; students from the School of Arts and Sciences preferred a more intimate and friendly relationship with their advisor; and Business students sought an experienced advisor. The findings of the Afshar and O'Hara (2006) study supported the idea that one type of advising is not effective for all students and that advisors should consider student traits when deciding which approach is most appropriate.

In another study designed to examine student characteristics, Nadler and Nadler (1993) explored the role of gender in advisement based on student gender, advisor gender, class year, and student major. Respondents to the survey study included undergraduates $(N=149)$ from a Midwestern university. Respondents represented all levels (freshman to senior) and included a broad section of majors.

Nadler and Nadler (1993) used analysis of variance (ANOVA) to examine the research questions. Alpha of .05 was used to determine statistical significance. Students 
saw female advisors $(X=2.31)$ more often than male advisors $(X=1.75, F=6.62, p=$ $.012)$. First-year students $(X=1.38)$ met with advisors the least often and seniors the most often $(X=2.81, F=3.20, p=.028)$. An interaction also occurred between student and advisor gender. Female students saw their female advisors $(X=2.06)$ more often than their male advisors $(X=1.46, F=4.30, p=.042)$. Male students did not vary in frequency between female $(X=1.86)$ and male $(X=1.86)$ advisor visits.

Respondents to the Nadler and Nadler (1993) study rated female advisors $(X=$ $14.88)$ as more empathetic than male advisors $(X=16.52, F=4.51, p=.037)$. First-year $(X=15.15)$ students rated their advisors as more empathetic than seniors $(X=17.33, F=$ $2.76, p=.049)$. Social science majors $(X=14.69)$ rated their advisors as having more empathetic concern than business majors $(X=17.36, F=11.07, p=.001)$.

In the policy capturing study described above, Mottarella et al. (2004) examined differences in advising preferences across types of students by grouping the captured policies according to student gender, age, ethnicity, classification, and previous advising experience. They used $t$-tests of independent samples to compare the standardized beta weights from individuals across groups and considered that a significant difference indicated one group was more influenced by a cue than another group. An alpha level of .0008 was used. Correlations were computed to examine the degree of covariation in regression weights across groups, and the researchers found that "the rank order of the six cues was similar across groups" (p. 55).

Although no differences were found in relative weights by ethnicity or classification, differences were found for gender, amount of advising experience, and age. The emotional nature of the advising relationship was a more important cue for 
women $($ mean $\beta=0.18 ; S D=0.29)$ than for men $($ mean $\beta=0.01 ; S D=0.28, t(177)=-$ $3.75, p<0.001, d=-.60$ ). Mottarella et al. (2004) found that women preferred a warm advising relationship. Participants who had advising experience with faculty or professional advisors preferred a female advisor (mean $\beta=.08 ; S D=.17$ ) more than those without prior advising experience $(\operatorname{mean} \beta=.01 ; S D=0.16, t(177)=-2.723, p<$ $0.007, d=-.41$ ). Participants less than 25 years of age preferred that their advisor knew them by name (mean $\beta=.34 ; S D=.34$ ) more than those participants older than 25 (mean $\beta=.07 ; S D=0.14, t(7.194)=4.283, p<0.003, d=1.78)$, indicating a different pattern of cue usage across gender and age groups.

Conclusion. The literature review revealed that student demographics are related to students' views of advising in multiple areas. Student gender, placement in remedial courses, and even student age may relate to student preference for developmental or prescriptive advisement (Crockett \& Crawford, 1989; Fielstein, Scoles, \& Webb, 1992; Smith \& Allen, 2006). Student gender, age, classification, ethnicity, and GPA might relate to whether students prefer male or female advisors or prefer faculty or staff advisors (Afshar \& O'Hara, 2006). Student gender and classification were related to students' views of advisor empathy and frequency of visits with their advisor (Mottarella et al., 2004; Nadler \& Nadler, 1993).

\section{First-generation Students}

Another student demographic studied in advising literature is generational status which relates to parental education level. Some institutions define first-generation status as indicative that neither parent ever attended an institution of higher learning. Other institutions more loosely define first-generation status as students with neither parent 
graduating from any institution of higher education. A review of the literature revealed that students with first-generation status may have experiences that continuing-generation students may not face that do not relate to any other demographic (i.e., age, gender, or ethnicity).

Barry, Hudley, Kelly, and Cho (2009) suggested that the college experience served as a life experience that would be difficult to navigate without a relevant social network. The purpose of their study was to investigate to whom students disclosed their college experiences and to examine differences in the social networks relative to generational status.

Participants in the survey included students $(N=1,539)$ from four colleges across the country (a $24 \%$ response rate). Respondents included first- $(n=556)$ and continuinggeneration ( $n=983)$ students. Information was gathered in three areas: (a) factors affecting college choices, (b) high school experiences, and (c) college experiences. Barry et al. (2009) measured disclosure on 13 items tied to discussing college experiences and social support. Respondents answered using a 4-point Likert-type scale anchored with $1=$ strongly disagree and $4=$ strongly agree. Exploratory Factor Analysis was completed on the 13 items. Cronbach's alpha estimated the "initial reliability of the items taken together as a measure of disclosure as well as for each identified and retained factor" (p. 60). The researchers reported that four factors accounted for $43.2 \%$ of the variance related to disclosure to groups including (a) friends at school $(\alpha=.72)$; (b) professionals $(\alpha=.71)$; (c) family $(\alpha=.57)$; and (d) friends from home $(\alpha=.48)$.

Barry et al. (2009) used independent sample $t$-tests for each of the four scales described above to measure differences in reported results between first-generation (first- 
gens) and continuing-generation (con-gens) students. First-gens reported less disclosure of college experiences than their peers. The result was significant but with a small effect size: family $\mathrm{t}(1,394)=2.28, \mathrm{p}=0.02$, Cohen's $\mathrm{d}=.1$; and friends from home $\mathrm{t}(1,393)=$ $3.50, \mathrm{p}=.00$, Cohen's $\mathrm{d}=.2$; friends at school $\mathrm{t}(1,377)=4.06, \mathrm{p}=.00$, Cohen's $\mathrm{d}=.2$. They found no significant differences in disclosure with professionals at school.

First- and continuing-generation students may experience differences related to background variables, achievement, and college experiences. Somers, Woodhouse, and Cofer (2004) examined the impact of such factors in their study of students $(N=24,262)$ attending 4-year institutions. The study used data from the National Postsecondary Student Aid Study of 1995-96 and included first-gens $(n=8,290)$ and con-gens $(n=$ 15,972). First-gens were defined as students with no postsecondary training.

Somers et al. (2004) used logistic regression to examine within-year progression of students from the fall 1995 semester to the spring 1996 semester. An analysis of the results from the study revealed differences between first-gens and con-gens. Of the 36 variables measured, 20 were significant in the first-gen model and 23 were significant in the con-gen model. Within the total model, 27 were significant.

Significant background variables included race and age. First-gen students declared as "other minority" were more likely to persist than white first-gens $(\beta=0.4048$, $p<.001$ ). For con-gens, Hispanic students were less likely to persist than non-Hispanic ( $\beta$ $=-0.1913, p<.001)$. First-gens older than 30 years were less likely to persist than firstgens between 22 and 30 years $(\beta=-0.2861, p<.001)$, while con-gens younger than age 22 were more likely to persist than those aged 23 to 29 years $(\beta=0.2446, p<.001)$. 
Somers et al. (2004) reported varying levels of persistence by class. First-year first-gens were less likely than sophomores, juniors, and seniors to persist $(\beta=0.2040$, 0.3769 , and 1.3543 , respectively; all at $p<.05$ ). Similarly, first-year con-gens were less likely than sophomores, juniors, and seniors to persist $(\beta=0.5809,0.6147,1.1782$, respectively; all at $p<.001$ ). Additional significant variables included (first-gens; congens): attending full-time $(\beta=0.6440, p<.01 ; \beta=0.8192, p<.001)$; working full-time ( $\beta$ $=-0.3771, p<.01 ; \beta=-0.3604, p<.01)$; and low GPA $(\beta=-0.7507, p<.01 ; \beta=-0.6478, p$ $<.001)$.

To discern whether first- and con-gens had equal access and could have the same success in institutions of higher education, Engle and Tinto (2008) used data from three U. S. Department of Education's National Center for Education Statistics (NCES) data sets to analyze the ways low-income first-generation (LIFG) students participated in higher education.

Data set one, The National Postsecondary Student Aid Study (NPSAS), was used to examine how students and their families paid for postsecondary education. Data set two, The Beginning Postsecondary Students (BPS) Study, followed students who first enrolled in postsecondary education in 1995-1996 and followed them over six years. Data set three, The Baccalaureate and Beyond Study (BBS), included about 11,000 undergraduates identified in the 1993 administration of the NPSAS study as having earned a bachelor's degree in the 1992-93 academic year. The students were first surveyed in their last year of undergraduate studies and followed up after 1, 4, and 10 years. 
For the purposes of their analysis, Engle and Tinto (2008) defined low-income status as a family with a combined annual income less than $\$ 25,000$. First generation status indicated that neither parent earned a bachelor's degree. LIFG students met both criteria.

Analysis of the data revealed that LIFG students experienced less success than their peers from the beginning. LIFG students were nearly $30 \%$ more likely to leave higher education after the first year than those who had neither risk factor. After six years, $11 \%$ of LIFG students had earned bachelor's degrees, compared with $55 \%$ of those without the two risk factors.

An analysis of the results of the Engle and Tinto (2008) study found that LIFG students who began their education in four-year institutions were seven times more likely to attain bachelor's degrees than those LIFG students who began at public two-year and for-profit institutions. Only $25 \%$ of LIFG students began their studies in a four-year institution.

In an effort to understand how different variables may affect various groups of students, the Lohfink and Paulsen (2005) study used data from an existing longitudinal study to "examine and compare the determinants of first-year to second-year persistence for first-generation and continuing-generation students at four-year institutions" (p. 410). They defined first-generation students as those whose parents had no postsecondary education. Continuing-generation students had at least one parent with some postsecondary training.

The data for this study came from the Beginning Postsecondary Students Longitudinal Survey-BPS: 96/01 (Wine, Heuer, Wheeless, Francis, Franklin, \& Dudley, 
2002). Participants were undergraduates $(N=4,184)$ who began their educational career at four-year institutions and included first-generation students $(n=1,167)$ and continuinggeneration students $(n=3,017)$.

Lohfink and Paulsen (2005) examined the relationship between first-to-secondyear persistence (FTSY) at the same institution and student background characteristics, precollege achievement, initial commitment (why students chose a particular institution), institutional variables, and college experiences. Logistic regression methods were used to examine the relationships between the DV and the IVs. Substantial differences existed between first-generation (first-gen) and continuing-generation students (con-gen). FTSY persistence was negatively affected by ethnicity (Hispanic) (Delta $p=-0.35394, p<$ .001 ), lower-income status (statistic not provided), and being female (statistic not provided). Conversely, none of those traits related to persistence for con-gen students.

Conclusion. The literature review revealed differences between first-gens and con-gens in several important areas. Barry et al. (2009) found that disclosure to family, friends from home, and friends from school was different for first-generation students than it was for continuing-generation students. No differences were found related to how first-gens and con-gens disclosed to professionals on the campuses.

Retention rates for first-gens are lower than con-gens. Race and age affected firstgen persistence differently than con-gen persistence. Differences between retention rates for first-gens and con-gens also were found related to student classification; student status (full- or part-time student); work requirements; and GPA (Engle \& Tinto, 2008; Lohfink \& Paulsen, 2005; Somers et al., 2004). Although substantial research on generational 
status can be found throughout the literature, few findings related to advising preferences of first-generation students.

\section{Conclusion}

Institutions of higher education have identified student retention as a priority (Lee $\&$ Rawls, 2010). The research findings support that academic advising plays a role in retention (Bai \& Pan, 2009; Crockett, 1978; Habley, 1981; Light, 2001; Noel, 1978; Spady, 1971; Tinto, 1993). A widespread call to provide developmental advising stemmed from the seminal Crookston (1972/1994) and O'Banion (1972/1994) studies that ties academic advising to cognitive- and psychosocial-development theories (Broadbridge, 1996; Chickering \& Associates, 1981; Ender, 1994; Frost, 1991; Thomas \& Chickering, 1984).

Institutional survey responses have indicated the need for developmental advising; however, few actually have achieved it (Habley, 1997, 2004). Student preference for developmental or prescriptive advisement has varied (Fielstein, 1987, 1989; Winston \& Sandor, 1984), and a review of the literature reveals a lack of congruence between the style of advising students prefer and what they receive (Alexitch, 1997; Hale et al., 2009; Mottarella et al., 2004).

Organizational models vary by type and size of institution (Habley, 1997). The individual providing the advisement also varies and depends upon the organizational model in place. The level of training available for advisors is inconsistent (Swanson, 2006; Waters, 2002). Faculty advisors may not believe their advising role provides any professional benefit and may find it difficult to manage along with the duties related to tenure considerations (Allen \& Smith, 2008; Biggs et al., 1975; Dillon \& Fisher, 2000; 
Severy et al., 1996; Shields \& Gillard, 2002). Both faculty and professional advisors give students a connection to the institution, a relationship described as important in retention research. The group that provides the best connection remains unidentified.

Faculty advisors can provide information and expertise on disciplines that professional advisors may not have available, but professional advisors can carve out more time for students (King, 1993). Some students prefer faculty advisors and others prefer professional advisors (Belcheir, 1998; Habley, 1994; Lynch, 2004). The reasons for student preference of faculty or professional advisor are as varied as the number of student demographics considered in the literature.

Student demographics have been found to be related to how students rate advising, their preference of advisor type and style, and how they interact with their social networks (Afshar \& O'Hara, 2006; Barry et al., 2009; Crockett \& Crawford, 1989; Engle \& Tinto, 2008; Fielstein, Scoles, \& Webb, 1992; Lohfink \& Paulsen, 2005; Nadler \& Nadler, 1993; Smith \& Allen, 2006; Somers et al., 2004). Those demographics include gender, age, ethnicity, classification, GPA, student status, and generational status.

Habley (2004) stressed the importance of examining academic advising within the framework of the institution it serves. Meeting the express goals of the Kentucky Postsecondary Education Improvement Act of 1997 (HB1) to raise the Kentucky standard of living and quality of life to the national average by the year 2020 provides the impetus for the current study. 


\section{CHAPTER III \\ METHODOLOGY}

This study examined student and advisor preferences for advisement style. The purpose of the study was to examine whether students and advisors at a public four-year university had similar perceptions of the intended role and outcomes of academic advising. Retention of students is a primary concern for most institutions of higher education, and academic advising has been positively tied to retention (Bai \& Pan, 2009; Crockett, 1978; Habley, 1981; Light, 2001; Noel, 1978; Spady, 1971; Tinto, 1993). Understanding both student and advisor expectations regarding academic advisement is important.

\section{Research Design}

Cross tabulation is one of the most common forms of analysis used in conjunction with categorical data (Grimm \& Wozniak, 1990) and allows the examination of frequencies of observations that belong to specific combinations of categories on more than one variable. To determine the style of advising offered on campus, it is important to understand whether or not advising style preference is the same campus-wide. Cross tabulations were used to test Hypotheses 1 and 2. Chi-square testing was used to measure the significance of the relationship between student preferences for advising style by college and the relationship between student and advisor preferences for advising by college. 
Multiple regressions allow the use of independent variables to predict the values of a dependent variable (Grimm \& Wozniak, 1990). In this study, predictor variables included student demographics (gender, ethnicity, age, classification, generational status, GPA, and college) and advisor demographics (type, age, gender, and college). The criterion variable was advising style preference. Multiple regressions were used to test Hypotheses 3 and 4 . Correlation analysis provided the basis for the strength and direction of any relationship found. Support for using the variables exists in the literature (Afshar \& O'Hara, 2006; Allen \& Smith, 2008; Barry et al., 2009; Beasley-Fielstein, 1986;

Belcheir, 1998; Crockett, 1985; Crockett and Crawford,1989; Dillon \& Fisher, 2000; Engle and Tinto, 2008; Fielstein, 1989; Fielstein et al., 1992; Habley, 1994; King, 1993; Larsen \& Brown, 1983; Lohfink and Paulsen, 2005; Lynch, 2004; Mottarella et al., 2004; Nadler and Nadler, 1993; Saving \& Keim, 1998; Shields \& Gillard, 2002; Somers et al., 2004; Weir et al., 2005; Winston \& Sandor, 1984a).

\section{Research Questions}

The present study addressed the following research questions:

1. Do students prefer developmental or prescriptive advising?

2. Do advisors prefer developmental or prescriptive advising?

3. Does student preference differ by college and/or department?

4. By college and/or department, do student and advisor preferences match?

5. Is there a relationship between certain student demographic variables (i.e., gender, ethnicity, age, classification, generational status, and GPA) and student preference for advising style? 
6. Is there a relationship between certain advisor demographic variables (i.e., age, gender, and advisor type) and advisor preference for advising style?

\section{Research Context}

The research took place at a regional comprehensive four-year university in the mid-south region of the United States. The university has six colleges: Arts and Letters, Business, Education and Behavioral Sciences, Health and Human Services, Science and Engineering, and the University College.

\section{Population and Sampling}

Advisors of record (full-time faculty members and professional advisors) employed by the colleges during the spring 2012 semester formed one population of interest. Advisors of record are determined by the department and entered into the student record system, BANNER, by the Academic Advising and Retention Center.

A report generated for the spring 2012 semester indicated that 1,961 faculty, staff, and administrators carried the advisor designation. Institutional technology clarified that all faculty (full- and part-time), some administrators, as well as some departmental staff may have the designation of academic advisor even though they may not actually advise students; some personnel designated as advisors may simply need access to remove an advising hold. Advising at the institution is mandatory for all students until they reach 90 earned hours and file an application for graduation.

Using an institutional report generation system, a compilation of advisors was created that listed 611 advisors of record with advisees assigned to them. A search of institutional records eliminated 236 advisors; those who advise only graduate students, advisors listed as secondary advisors, an advisor for an on-campus academy housing 
students younger than 18 years old, and the researcher. Also eliminated were individuals designated as advisors who no longer work at the institution. Advisors with fewer than five advisees also were eliminated, resulting in a final list of active advisors $(N=375)$.

Using a sample size calculator, it was determined that 190 advisors needed to be drawn from the population to reach a $95 \%$ confidence level. The sample of advisors was stratified by college and number of advisees. Furthermore, to give each undergraduate an equal probability of selection for the study, the advisors were drawn using probability proportionate to size sampling (Neuman, 2006).

The other population of interest for this study included degree-seeking undergraduates, associate and baccalaureate, enrolled at the university for the spring 2012 term and whose advisor of record belonged to the data set described above. The reports utilized to generate the list of active advisors showed a total of 15,429 students tied to the 375 active advisors and a total of 12,597 students tied to the advisor sample. The final student sample included the advisees $(N=4,711)$ of the randomly selected advisors who participated in the survey. A sample size calculator was used to determine that 355 student responses would best reflect the undergraduate student population.

\section{Experience with Research Personnel}

Because the researcher is a professional advisor at the institution, some students may have been exposed to her through prior advising experiences. She also serves as a freshman experience faculty member and students may have been exposed to her through prior enrollment in her courses. Faculty may have been exposed to her through daily interaction within the college or across campus in various capacities. Student and advisor confidentiality was assured through the use of a password-protected secure survey site. 


\section{Survey Administration}

The survey administration was via web delivery. To generate the best possible response rate, emails were sent out under the signature of the researcher and the chair of the dissertation committee asking for participation in an academic advising survey. The recipients of the first email were the advisors $(N=220)$ from the randomly generated sample. The survey software used by the researcher's home institution provided anonymity of responses while allowing the researcher to view whether an advisor responded. The email contained confidentiality information and provided a link to the survey. Endorsement of the project by the dissertation chair provided advisors a measure of security that the survey was not a hoax and was safe to access from their computers.

The second email was sent to the student advisees of those advisors who took part in the survey. The email invited participation through a provided secure link and contained confidentiality information. Students younger than 18 years of age were asked to not respond to the survey.

Though web delivery of surveys presents constraints such as coverage of the population, Dillman (2000) related that Internet access reduced the problem of coverage for certain populations. Students at the university had in-dorm (wired and wireless) Internet access, and those who may not have had a personal computer had 24-hour-a-day access (wired and wireless) at multiple computer labs across the campus. Faculty and staff had in-office access (wired and wireless) across the university.

The findings of the Cook, Heath, and Thompson (2000) meta-analysis revealed response rates for web or Internet surveys from $34.6 \%$ to $39.6 \%$. They summarized that response rates might be improved through the "number of contacts, personalized 
contacts, and pre-contacts" (p. 833). A reminder email was sent to both advisors and students.

\section{Instrument}

The primary instrument used to gather data in this quantitative study was the Academic Advising Inventory (AAI) first introduced by Winston and Sandor (1984b). Permission to use the AAI was granted to anyone involved in dissertation research by the authors in October 2002 (See Appendix A - Preface and Permission for Use). This instrument was administered to both students and to faculty and professional advisors.

Winston and Sandor (2002) emphasized the need for evaluation of current academic advising programs to determine (a) what "should be happening" (p. 4) and (b) what is actually occurring. They stated that the AAI provides "a mechanism for gathering data from different institutions or different programs within large institutions and making meaningful comparisons across institutions or programs" (p. 9).

Winston and Sandor (2002) first created the AAI in 1984 in response to the need for a "theoretically grounded measurement tool" (p. 9). They generated 62 statements related to advising, as described by Crookston (1972/1994). The 62 statements were intended to be paired ( 31 statements) to represent contrasting advising styles (developmental or prescriptive). All statements were randomly ordered and provided to eight advisement experts for identification as developmental or prescriptive. Items that were not clearly discerned as developmental or prescriptive were discarded and resulted in 22 item-pairs. 
Ender, Winston, and Miller (1982) stated,

developmental advising is a process, $\ldots$ is continuous and is established on the basis of the advisor-advisee relationship. . . is concerned with human growth, . . is goal related,. . . and requires establishment of a caring human relationship. (p. 7)

Winston and Sandor (2002) provide an overview of prescriptive advising that "results when students report a relationship based on authority, with the advisor functioning as the expert" (p. 11) who provides diagnoses of student problems and directs the students in their responses. They referred to prescriptive advising relationships as "formal and distant" (p. 11).

The original instrument was tested on undergraduates $(n=412)$ at five colleges and universities. Item and factor analysis resulted in an additional five pairs being discarded based on contribution to the overall scale. A second test containing the 17 items was administered to undergraduates $(n=506)$ from five institutions. Winston and Sandor (2002) reported that item and factor analysis and a varimax rotation resulted in the current instrument of 14 pairs of items that make up the Developmental-Prescriptive Advising Scale (DPA) and three sub-scales. The subscales include (a) Personalizing Education (PE), Academic Decision-Making (ADM), and Selecting Classes (SC). The original AAI contained five parts as described below.

Part I, the DPA "scale describes the nature of the advising relationship and the breadth of topics and concerns addressed during advising sessions" (Winston \& Sandor, 2002, p. 11). The PE subscale reflects advisor concern for the student's total education (career planning, extracurricular activities, goal setting, etc.). The ADM subscale focuses 
on individuals with responsibility for making and implementing academic decisions related to majors, minors, or course registration. The SC subscale focuses on course selection based on needs related to academic plans.

Part II, the Advisor-Advisee Activity Scales, lists 30 common advising activities that make up five scales including (a) Personal Development and Interpersonal Relations (PDIR), (b) Exploring Institutional Policies (EIP), (c) Registration and Class Scheduling (RCS), (d) Teaching Personal Skills (TPS), and (e) Academic Majors and Courses (AMC). Students based their responses on current year experiences and related the number of times each event took place.

Part III of the AAI included five items related to student satisfaction with advising. Participants responded on a 4-point Likert-type scale anchored with Strongly Disagree and Strongly Agree. Part IV of the AAI was designed to gather demographic information, and Part V restated the 14 paired items from Part I. Respondents reported on their opinion of the ideal academic advisor in Part V.

Internal consistency and reliability for the DPA scale and subscales were estimated using Cronbach's Alpha (Winston \& Sandor, 2002). The alpha coefficient for the overall DPA was .78. The subscale alphas ranged from .42 (2-item SC subscale) to .81 (8-item PE scale), indicating homogeneity and stability. Winston and Sandor used Pearson-product moment correlations to determine independence and noted that the measures seemed "to be relatively independent measures" (p. 15).

Winston and Sandor (2002) related that Parts I and II of the original inventory were to be used in their entirety, and individual items could not be removed for use in other instruments. However, users could opt out of Part II entirely and could alter Parts 
III and IV to fit institutional need. The original Part II was not included in the survey administered as part of the current survey. Instead, Parts III, IV, and V were renumbered as Parts II, III, and IV for clarity in administration.

Students responded to Part I based on actual advisement experiences, and advisors were instructed to think "I" when they read "my advisor" to make the survey applicable to the advising they offered students. Part II of the administered survey included the five items related to student satisfaction with advisement. Both student and advisor participants responded on a 4-point Likert-type scale anchored with Strongly Disagree and Strongly Agree. The items were coded as A $($ Strongly Disagree $)=1, \mathrm{~B}($ Disagree $)=$ 2, C (Agree) $=3$, and D (Strongly Agree) $=4$, as indicated by Winston and Sandor (2002).

Part III of the AAI gathered demographic information. Student demographics included gender, ethnicity, age, classification, generational status, and GPA. Additional information included where and by whom students had been advised. Advisor demographics included age, gender, and type (faculty or professional). Additional information included the overall length of time they had served as an advisor and the length of time they had served at the current institution.

Part IV restated the 14 paired items from Part I. Students responded to Part IV based on what they considered to be their ideal advising experience, and advisors were instructed to think "I" when they read "my advisor" to make the survey applicable to the advising they would most like to offer students.

Winston and Sandor (2002) provided reliability for the DPA based on student responses to advising they had received. They did not report reliability for the scale as 
used in Part IV of the AAI - student preference for advising. A comprehensive psychometric evaluation including factor, scale, and reliability analysis was conducted on the student data in the current study. Consistent with recommended best practice, the extraction method of maximum likelihood utilizing an oblique rotation was the factor analysis employed (Costello \& Osborne, 2005).

Reliability analysis of the 14 items comprising the DPA (preference) scale suggested strong reliability with a Cronbach's alpha of .869 . One item (question 1) was noted as potentially increasing scale reliability if deleted. Factor analysis, however, revealed the 14 items could be considered either as a single factor scale or as two factors. Examination of the loading on the factors in the pattern matrix revealed that the first factor focused on advising matters beyond academic ones, while the second factor dealt solely with academic issues. However, a single factor solution was possible and fit the theoretical model.

\section{Additional Variables}

\section{Student Demographic Variables}

Gender. As of spring 2012, official enrollment data indicated that $57.55 \%$ of the undergraduate population was female. Research related to advising and retention supported gender as a significant predictor of preference for certain advising functions (Smith \& Allen, 2006) and when considering ratings of advisor characteristics (Afshar \& O'Hara, 2006). Gender was analyzed relative to advising style preference.

Age. Traditional students at the university under study are those younger than age 25. Non-traditional students are those aged 25 years and above. Most students enrolled in spring 2012 were traditional students $(77.37 \%)$. 
Classification. The literature review supported analysis of student perceptions of advising needs over time (Afshar \& O'Hara, 2006; Engle \& Tinto, 2008; Lohfink \& Paulsen, 2005; Somers et al., 2004). The spring 2012 undergraduate population at the university under study consisted of $21.87 \%$ freshmen, $19.47 \%$ sophomores, $19.33 \%$ juniors, and $29.15 \%$ seniors. Just over ten percent (10.17\%) were listed as "other" and included those students seeking a second undergraduate degree and those taking undergraduate classes but not seeking a degree.

Status. Full-time students represented $76.96 \%$ of all undergraduates in the spring 2012 semester. Only $23.04 \%$ of undergraduates attended school on a part-time basis. Most non-traditional students were part-time students who had other responsibilities that may have taken precedence over school-related requirements. Those students may prefer a different advising style than full-time students (Engle \& Tinto, 2008; Lohfink \& Paulsen, 2005; Somers et al., 2004). Student status was analyzed to determine the existence of a preference for advising style.

Ethnicity. All but $19.13 \%$ of students enrolled in the spring 2012 semester were classified as White. By group, the breakdown indicated that African-Americans made up $10.87 \%$ of the population followed by Non-Resident Aliens (2. 85\%), Hispanics (1.88\%), students reporting two or more races $(1.39 \%)$, and those not reporting their race $(1.21 \%)$. Asians and American Indians/Alaskan Natives represented 1.18\% of the population. Student ethnicity was analyzed regarding advising style preference.

Generational Status. Parental educational level was used as a proxy for firstgeneration status. The variable was defined by two groups $(0=$ continuing generation - 
either parent earned a bachelor's degree or higher; 1 = first generation - neither parent earned a bachelor's degree). Students self-reported parental educational level on their admissions application. Data from the Office of Institutional Research indicated a firstgeneration population of $38.71 \%$ in the spring 2012 semester.

\section{Advisor Demographic Variables (type, age, gender, college)}

A review of the literature revealed that advisor type (faculty or professional), age, gender, and college can influence student preference for advisement style. The variables also have been related to differences in advisor preference for advising delivery (prescriptive or developmental). The variables were analyzed for advisor preferences (Afshar \& O'Hara, 2006; Beasley-Fielstein, 1986; Dillon \& Fisher, 2000; Lowe \& Toney, 2000; Lynch \& Stucky, 2000; O'Banion, 1972/1994).

\section{Hypotheses}

Research hypotheses were developed for Research Questions 3 through 6. Null hypotheses were tested at the $p<.05$ level. An alpha level of .05 was chosen for statistical significance testing and is referred to as the "traditional level of significance" in the literature (c.f. Bickman \& Rog, 1998; Dillman, 2006).

Null $\mathrm{H}_{1}$ : Student preference of advising style will not differ by college and/or department.

Null $\mathrm{H}_{2}$ : Student and advisor preferences of advising style will not differ by college and/or department.

Null $\mathrm{H}_{3}$ : Student demographic variables (gender, age, classification, status, ethnicity, generational status) are not related to student preference for advising style. 
Null $\mathrm{H}_{4}$ : Advisor demographic (type, age, gender, college) variables are unrelated to advisor preference for advising style delivery.

\section{Summary}

Academic advisement takes place on most university and college campuses across the United States. The best style of advising to offer students has been researched over and over. The literature review revealed uncertainty related to national surveys of advisors and students and encouraged smaller institutional reviews. The study was guided by six questions designed to determine whether students preferred one advising style over the other, whether advisors preferred one advising style over the other, and whether student and advisor demographics played a role in the preferences. Expectations of advisement were compared to actual advising experiences to determine whether students received the advising they expected and preferred, and whether advisors utilized the advising style they preferred. To address the questions, an existing survey (Winston \& Sandor, 1984b) was administered to a random sample of advisors and then to the advisees of those advisors who chose to respond to the survey. The following chapter provides statistical analysis of the results of the surveys, and the implications of the results are presented in Chapter V. 


\section{CHAPTER IV}

\section{RESULTS}

The purpose of the study was to examine whether students and advisors at a public, four-year university had similar perceptions of the intended role and outcomes of academic advising. Additionally, congruence between preference for advising style and what was provided or received was examined.

\section{Research Questions}

Results of data analyses are presented for the following six research questions:

1. Do students prefer developmental or prescriptive advising?

2. Do advisors prefer developmental or prescriptive advising?

3. Does student preference differ by college and/or department?

4. By college and/or department, do student and advisor preferences match?

5. Is there a relationship between certain student demographic variables (i.e., gender, ethnicity, age, classification, generational status, and GPA) and student preference for advising style?

6. Is there a relationship between certain advisor demographic variables (i.e., age, gender, and advisor type) and advisor preference for advising style?

Four hypotheses guided data analysis and each null hypothesis was tested at the $p<.05$ level: 
Null Hypothesis 1: $\quad$ Student preference of advising style will not differ by college and/or department.

Null Hypothesis 2: Student and advisor preferences of advising style will not differ by college and/or department.

Null Hypothesis 3: Student demographic variables (gender, age, classification, status, ethnicity, generational status) are not related to student preference for advising style.

Null Hypothesis 4: Advisor demographic (type, age, gender, college) variables are not related to advisor preference for advising style delivery.

\section{Survey Sampling of Advisors}

Two groups of participants were surveyed in the spring 2012 semester: advisors and their students. First, advisors were surveyed. Then the students of those responding advisors were asked to participate. Of the total population of advisors $(N=375), 220$ were sampled across the university's campuses. The initial survey invitation was sent through campus email. This was problematic in that responding advisor emails were not captured and their associated advisees could not be sent an invitation to participate. It is unfortunate that 67 people had already responded to the first survey before this was discovered, although several of their responses had been partial responses. This survey was closed, the email issue fixed, and a second email invitation was sent explaining the problem and again asking for participation. This was followed up with a reminder email. Fifty-five advisors responded to the second survey. After eliminating blank surveys and partial responses, 42 surveys were included in the data analyses (response rate $=25 \%$ ). 
To assess the extent of bias in the advisor sample, the sample statistics were compared to the population parameters on age, advisor type, and college affiliation. As shown in Table 1, 9 males (21.4\%) and 33 females (78.6\%) responded to the survey. Though the percentage of females in the advisor population (47.5\%) was not substantially different from the percentage of females in the sample as it was randomly drawn (49.5\%), females were clearly overrepresented among those in the sample that responded to the survey $(47.5 \%, 49.5 \%$, and $78.6 \%$, respectively). While numerically more faculty advisors (25) than professional advisors (17) responded to the survey, professional advisors were overrepresented percentagewise. Faculty advisors accounted for $92.0 \%$ of the total advisor population and $89.1 \%$ of the sample to which invitations were sent and 59.5 of the responding advisors.

As for college affiliation, this university was comprised of six colleges - the College of Education and Behavioral Sciences (CEBS), the College of Health and Human Services (CHHS), the Gordon Ford College of Business (GFCB), the Ogden College of Science and Engineering (OCSE), the Potter College of Arts and Letters (PCAL), and the University College (UC). These colleges will be mentioned only by their initials in the following descriptive discussions. Exploratory students generally receive their advising from Academic Advising and Retention Center (AARC) staff. These students and their advisors would have responded "No College" when asked their affiliation and will be mentioned by the AARC abbreviation.

Though the population and sample percentages for each college are close together, overrepresentation occurred in the respondent sample. The largest underrepresentation was in the OCSE where advisors made up $28.3 \%$ of the population, 
$25.9 \%$ of the sample, and only $7.1 \%$ of total respondents. The UC advisors had the largest overrepresentation where they comprised $13.8 \%$ of the population and $21.4 \%$ of the respondents.

Table 1

Advisor Gender, Advisor Type, and Participants by College

\section{Survey Sampling of Students}

There are several issues to consider regarding the current undergraduate population $(N=16,732)$, the undergraduate sample $(n=4,711)$, and the final number of undergraduate respondents $(n=300)$ in this study. The Office of Institutional Research (IR) at the university provided undergraduate demographic information and totals for the spring 2012 semester at the point of the survey administration (Hume, personal communication, March 5,2012). The original list of active advisors on campus $(N=611)$ represented a population of undergraduates $(N=18,758)$ larger than the current undergraduate population provided by IR. After culling the advisor listing (as described 
in Chapter III), the total possible advisee sample dropped $(N=15,429)$. The list of students tied to advisors provided a way to compare the preferences and delivery of advising between advisors and students. That population, though, could not be sorted by the demographics provided for the total university. For the purposes of this research, the undergraduate population $(N=16,732)$ reflected the number provided by IR rather than the actual number of students from which the sample was drawn.

To measure agreement between students and advisors on their preferences for advising style surveying the students of advisors who responded to the survey was important. As advisors' responses entered the system, a list of their advisees' email addresses was generated and the students were sent an invitation to participate via email. Students of the 42 advisors who fully completed the survey were asked to participate. The total number of students sampled in this fashion was 4,711 . The email included a link to a secure site and the survey was administered online. When student responses slowed, a reminder email was sent to all students who had received an invitation to participate. Although 375 students initiated the survey, the final sample included 300 respondents after missing data were removed from calculations (response rate $=8.0 \%$ ).

To assess potential bias in student sample, several demographic statistics were compared to their corresponding population parameters as reported by Institutional Research. As shown in Table 2, females were overrepresented in the student sample. Eighty-two males (27.3\%) and 216 females (72.0\%) completed the survey. The overall population of undergraduates was $42.4 \%$ males and $57.5 \%$ females. Moreover, nontraditional students were overrepresented. Though most students $(77.4 \%)$ were 
traditionally aged ( 18 to 25 years), non-traditional students ( 25 years and older) accounted for $34.0 \%$ of respondents, while they were only $22.6 \%$ of the population.

Table 2

Student Gender and Age

\begin{tabular}{llccc}
\hline Demographic & Group & Frequency & $\begin{array}{c}\text { Respondents } \\
\text { Percent }\end{array}$ & $\begin{array}{c}\text { Population } \\
\text { Percent }\end{array}$ \\
\hline \multirow{2}{*}{ Gender } & Male & 82 & 27.3 & 42.4 \\
& Female & 216 & 72.0 & 57.5 \\
& Missing & 2 & 0.7 & \\
\hline \multirow{3}{*}{ Age } & 18 to 25 years & 197 & 65.7 & 77.4 \\
& 25 years and older & 102 & 34.0 & 22.6 \\
& Missing & 1 & 0.3 & \\
\hline
\end{tabular}

Regarding race/ethnicity of students, the racial composition was on par with the overall undergraduate population. The majority (82.0\%) of student respondents (246) reported their race as White. The population percentage for White students was $80.9 \%$. In further analysis, the race/ethnicity categories were collapsed to compare White students versus non-White students.

Table 3

Student Race/Ethnicity

\begin{tabular}{llrrr}
\hline Demographic & Group & Frequency & $\begin{array}{c}\text { Respondents } \\
\text { Percent }\end{array}$ & $\begin{array}{c}\text { Population } \\
\text { Percent }\end{array}$ \\
\hline \multirow{5}{*}{ Race/Ethnicity } & Non Resident Alien & 0 & 0.0 & 2.6 \\
& Black/African American & 21 & 7.0 & 10.9 \\
& Asian & 4 & 1.3 & 0.3 \\
& Hispanic (of any race) & 10 & 3.3 & 1.9 \\
& White & 246 & 82.0 & 80.9 \\
& 2 or more races & 4 & 1.3 & 1.4 \\
& Pacific Islander & 2 & 0.7 & 0.0 \\
& No Answer & 13 & 4.3 & 1.2 \\
\hline
\end{tabular}


Student demographic data continues in Table 4 with student classification.

Freshmen were underrepresented; freshmen were $12 \%$ of respondents, compared with $21.9 \%$ of the population. Juniors (89) were overrepresented. They accounted for $29.7 \%$ of respondents and only $19.3 \%$ of the population. There were more full-time students (252) than part-time (47). The part-time group was underrepresented in the respondent population. Lastly, there were more first-generation respondents (151) than continuing generation students (149). First-generation students represented $38.7 \%$ of the population and $50.3 \%$ of respondents.

Table 4

Student Classification, Status, Generational Status, and GPA

\begin{tabular}{clccc}
\hline \multirow{2}{*}{ Demographic } & Group & Frequency & $\begin{array}{c}\text { Respondents } \\
\text { Percent }\end{array}$ & $\begin{array}{c}\text { Population } \\
\text { Percent }\end{array}$ \\
\hline \multirow{2}{*}{ Classification } & Freshmen & 36 & 12.0 & 21.9 \\
& Sophomores & 52 & 17.3 & 19.5 \\
& Seniors & 89 & 29.7 & 19.3 \\
& Other & 101 & 33.7 & 29.1 \\
& Missing & 21 & 7.0 & 10.2 \\
\hline \multirow{2}{*}{ Status } & Part-time student & 1 & 0.3 & \\
& Full-time student & 252 & 84.0 & 77.0 \\
& Missing & 1 & 0.3 & \\
\hline \multirow{2}{*}{ Generational } & First Generation & 151 & 50.3 & 38.7 \\
\cline { 2 - 4 } & Continuing Generation & 149 & 49.7 & 61.3 \\
\hline
\end{tabular}




\section{Additional Descriptive Statistics}

Additional descriptive statistics beyond those previously above were calculated for advisor and student samples on all variables of interest. Both advisor and student samples were asked to respond to five statements concerning their satisfaction with advising as well as the type of advising they provided/received and the type of advising they would prefer to provide/receive. Advisors also were asked about their years advising at WKU and total years advising. Students also were surveyed as to their GPA, where and by whom they had received advising, their college, and their department ${ }^{1}$.

\section{Advisor Sample}

Table 5 shows the number of years respondents reported having served as an advisor on this campus and the number of years they reported having advised overall. Twenty-seven advisors (64.3\%) have advised on this campus from 1 to 10 years, and 23 (54.8\%) have been advising from 1 to 10 years overall.

Ten advisors $(23.8 \%)$ have advised on this campus from 11 to 20 years and five advisors $(11.9 \%)$ for more than 20 years. Thirteen advisors (30.9\%) have been advising from 11 to 20 years, and six advisors (14.3\%) have passed 20 years.

\footnotetext{
${ }^{1}$ Because of low response rates and concern for respondent identity, departmental data will not be presented in this study beyond initial frequency distributions for either sample.
} 
Table 5

\begin{tabular}{ccccc}
\hline & \multicolumn{5}{c}{ Years as Advisor On Campus and Overall and Advisor Age Range } \\
\cline { 2 - 5 } Years as Advisor & Frequency & Percent & Frequency & Percent \\
\hline 1 On Campus & 14 & 33.3 & 12 & 28.6 \\
6 to 10 years & 13 & 31.0 & 11 & 26.2 \\
11 to 15 years & 7 & 16.7 & 9 & 21.4 \\
16 to 20 years & 3 & 7.1 & 4 & 9.5 \\
more than 20 years & 5 & 11.9 & 6 & 14.3 \\
\hline Age & Frequency & Percent & & \\
\hline 22 to 34 years & 5 & 11.9 & & - \\
35 to 44 years & 13 & 30.9 & & - \\
45 to 54 years & 9 & 21.4 & & - \\
55 to 64 years & 13 & 31.0 & & - \\
65 and over & 2 & 4.8 & & - \\
\hline
\end{tabular}

Advisor age ranges were not available for the sample $(n=220)$ or for the population $(N=375)$

Table 6 shows advisor satisfaction responses. The first two statements related to advisors' perceptions of how well they had performed some advising duties. The last three statements related to advisor workload. All advisors indicated agreement or strong agreement on the first two questions. Responses related to the workload questions ranged from 1 (strongly disagree) to 4 (strongly agree). The question with the highest level of disagreement stated: Advising is considered (for faculty advisors) in tenure guidelines in my college. Nine advisors (21.4\%) strongly disagreed and five advisors (11.9\%) disagreed. Respondents indicated some disagreement with the last two statements, but $90.5 \%$ agreed or strongly agreed that advising was valued in their college, and $80.9 \%$ agreed or strongly agreed that sufficient time was available for advising sessions. 
Table 6

\begin{tabular}{llcc} 
Advisor Satisfaction Responses & & & \\
\hline Survey Statement & Survey Response & Frequency & Percent \\
\hline I am satisfied in general with the & Agree & 23 & 54.8 \\
academic advising I have provided. & Strongly Agree & 19 & 45.2 \\
\hline $\begin{array}{l}\text { I provide accurate information about } \\
\text { courses, programs, and requirements } \\
\text { through academic advising. }\end{array}$ & Strongly Agree & 14 & 33.3 \\
& & 28 & 66.7 \\
\hline $\begin{array}{l}\text { Advising is considered (for faculty } \\
\text { advisors) in tenure guidelines in my }\end{array}$ & Strongly Disagree & 9 & 21.4 \\
college. & Disagree & 5 & 11.9 \\
& Agree & 15 & 35.7 \\
\hline Advising is valued in my college. & Strongly Agree & 10 & 23.8 \\
& Strongly Disagree & 1 & 2.4 \\
& Disagree & 3 & 7.1 \\
& Agree & 20 & 47.6 \\
& Strongly Agree & 18 & 42.9 \\
\hline Sufficient time is available for & Strongly Disagree & 2 & 4.8 \\
advising sessions. & Disagree & 6 & 14.3 \\
& Agree & 26 & 61.9 \\
& Strongly Agree & 8 & 19.0 \\
\hline
\end{tabular}

Note. $\mathrm{n}=42$. Error in totaling due to rounding or missing responses.

\section{Student Sample}

Table 7 illustrates where and by whom students received advising. The university has extended campus offices in Elizabethtown, Radcliff, Ft. Knox, Glasgow, and Owensboro. Elizabethtown, Radcliff, and Ft. Knox are in close proximity and students in that area may receive advising from any of those offices.

The university also has an offsite location called the South Campus where students pursuing two-year degrees take most of their classes and receive advising. Most respondents (265) reported being advised on the Main Campus (88.3\%) but students from all campuses took part in the survey. Most students were advised in their college of record $(94.3 \%)$, in their major department $(78.7 \%)$, and by their advisor of record $(80.3 \%)$. Six students $(2 \%)$ reported NA as their college of record and $21(7 \%)$ reported 
NA related to being advised in their major department. Nineteen students $(6.3 \%)$ were unsure whether they were advised by their advisor of record. Thirty-three students reported receiving advising from the AARC (11\%), 6 from their athletic advisor, 13 from their honors advisor, and 9 from their student services advisor.

Table 7

Student Advising Received-Campus, College, Department, Advisor, and Outside

\begin{tabular}{|c|c|c|c|}
\hline Question & $\begin{array}{l}\text { Survey } \\
\text { Response }\end{array}$ & Frequency & Percent \\
\hline \multirow{5}{*}{$\begin{array}{c}\text { Advised on } \\
\text { Which Campus? }\end{array}$} & Main & 265 & 88.3 \\
\hline & South & 5 & 1.7 \\
\hline & Elizabethtown/Radcliff/Ft. Knox & 14 & 4.7 \\
\hline & Glasgow & 3 & 1.0 \\
\hline & Owensboro & 11 & 3.7 \\
\hline \multirow{3}{*}{$\begin{array}{l}\text { Advised in } \\
\text { College of Record? }\end{array}$} & Yes & 283 & 94.3 \\
\hline & No & 9 & 3.0 \\
\hline & NA & 6 & 2.0 \\
\hline \multirow{3}{*}{$\begin{array}{c}\text { Advised in } \\
\text { Major Department }\end{array}$} & Yes & 236 & 78.7 \\
\hline & No & 42 & 14.0 \\
\hline & NA & 21 & 7.0 \\
\hline \multirow{3}{*}{$\begin{array}{l}\text { Advised by } \\
\text { Assigned } \\
\text { Advisor? }\end{array}$} & Yes & 241 & 80.3 \\
\hline & No & 39 & 13.0 \\
\hline & Unsure & 19 & 6.3 \\
\hline \multirow{5}{*}{$\begin{array}{c}\text { If not College } \\
\text { or Department, } \\
\text { Where or By } \\
\text { Whom? }\end{array}$} & Central Advising Office & 33 & 11.0 \\
\hline & Athletic Advisor & 6 & 2.0 \\
\hline & Honors Advisor & 13 & 4.3 \\
\hline & Student Support Services Advisor & 9 & 3.0 \\
\hline & Other & 110 & 36.7 \\
\hline
\end{tabular}

Note. $\mathrm{n}=300$. Error in totaling due to missing cases and rounding.

Most respondents (221) reported their GPA as falling in the 3.0-4.0 range

(73.6\%). Seventy-two students were in the $2.0-3.0$ range (24\%), and six students $(2 \%)$ reported a GPA of less than 2.0.

Table 8 shows student respondents by college. The highest number, 103 students (34.3\%), reported GFCB as their college, and 68 students (22.7\%) from the CEBS 
responded. Third was CHHS with 36 students (12\%), followed by the UC with 35 students (11.7\%). Students from the OCSE (22), PCAL (18), and the AARC (9) accounted for $16.3 \%$ of the total, and nine students (3\%) did not indicate their college of record.

Table 8

Student Respondents by College

\begin{tabular}{lcc}
\hline College Name & Frequency & Percent \\
\hline College of Education and Behavioral Sciences & 68 & 22.7 \\
College of Health and Human Services & 36 & 12.0 \\
Gordon Ford College of Business & 103 & 34.3 \\
No College & 9 & 3.0 \\
Ogden College of Science and Engineering & 22 & 7.3 \\
Potter College of Arts and Letters & 18 & 6.0 \\
University College & 35 & 11.7 \\
Missing & 9 & 3.0 \\
\hline
\end{tabular}

Note. $\mathrm{n}=300$.

Table 9 reports student responses to five satisfaction statements. At least $90 \%$ of respondents agreed or strongly agreed that advising was available as needed and indicated that sufficient time was available during advising sessions. Fewer students (86\%) agreed or strongly agreed that they received accurate information about courses, programs, and requirements through academic advising and $84 \%$ were satisfied with advising in general. Sixteen percent (16\%) of students disagreed or strongly disagreed that they received sufficient prior notice about deadlines related to institutional policies and procedures. 
Table 9

Student Satisfaction Responses

\begin{tabular}{llcc}
\hline Survey Statement & Survey Response & Frequency & Percent \\
\hline I am satisfied in general with the & Strongly Disagree & 13 & 4.3 \\
academic advising I have received. & Disagree & 32 & 10.7 \\
& Agree & 123 & 41.0 \\
& Strongly Agree & 129 & 43.0 \\
\hline I have received accurate information & Strongly Disagree & 10 & 3.3 \\
about courses, programs, and & Disagree & 29 & 9.7 \\
requirements through academic & Agree & 118 & 39.3 \\
advising. & Strongly Agree & 140 & 46.7 \\
\hline Sufficient prior notice has been provided & Strongly Disagree & 12 & 4.0 \\
about deadlines related to institutional & Disagree & 36 & 12.0 \\
policies and procedures. & Agree & 122 & 40.7 \\
& Strongly Agree & 127 & 42.3 \\
\hline Advising has been available when I & Strongly Disagree & 5 & 1.7 \\
needed it. & Disagree & 20 & 6.7 \\
& Agree & 119 & 39.7 \\
& Strongly Agree & 153 & 51.0 \\
\hline Sufficient time has been available during & Strongly Disagree & 5 & 1.7 \\
advising sessions. & Disagree & 22 & 7.3 \\
& Agree & 124 & 41.3 \\
& Strongly Agree & 146 & 48.7 \\
\hline
\end{tabular}

Note. There are three missing responses $(1 \%)$ from each statement.

\section{Research Hypotheses}

\section{Research Question One}

The first research question was as follows: Do students prefer developmental or prescriptive advising?

Student scores on all 14 questions concerning advising preference were summed. The manual for the Academic Advising Inventory (Winston \& Sandor, 2002) relates that scores from 14 to 56 "indicate that prescriptive advising is prevalent" (p. 11) and scores from 57 to 112 "indicate developmental advising" (p. 11). A frequency table was created 
to show student preferences regarding developmental and prescriptive advising style.

Table 10 shows that 69 students (23.4\%) preferred prescriptive advising and that 226 students $(76.6 \%)$ preferred developmental advising.

Table 10

Student Advising Style Preferences

\begin{tabular}{lrrr}
\hline Advising Style & Frequency & Percent & $\begin{array}{c}\text { Cumulative } \\
\text { Percent }\end{array}$ \\
\hline Prescriptive & 69 & 23.4 & 23.4 \\
Developmental & 226 & 76.6 & 100.0 \\
Total & 295 & 100.0 & \\
\hline
\end{tabular}

\section{Research Question Two}

The second research question was: Do advisors prefer developmental or prescriptive advising?

As with the student sample, scores on all 14 questions concerning advising preference were summed. According to the scale creators the cut-point between developmental and prescriptive advising is 56.5 . Those scoring below have a preference for prescriptive advising; those above prefer developmental advising. A review of frequency data for advisor responses showed that all 42 advisors (100\%) preferred to deliver developmental advising.

\section{Research Question Three}

The third research question was: Does student preference differ by college and/or department? The null hypothesis for this research question stated that student preference of advising style would not differ by college and/or department. The hypothesis was tested using bivariate analysis to compare student preferences by college. No significant 
results were found to indicate that college had an effect on student preferred advising style. The null hypothesis was supported.

\section{Research Question Four}

Research question four stated: By college and/or department, do student and advisor preferences match? The null hypothesis for this research question stated that student and advisor preferences of advising style would not differ by college and/or department. As discussed in the response to research question one, students preferred developmental advising; however, there are a number of students who preferred prescriptive advising. In research question two, it was found that all advisor respondents self-reported a preference for developmental advising. A difference of the proportions test was performed (Agresti \& Finlay, 1986) with the null hypothesis being no difference between student and advisor preferences in advising. The z-score testing this hypothesis was $9.36(p<.001)$, which strongly suggests that there is a significant difference between student preference and advisor preference overall; however, number of professors by college is too small to do individual college or department comparisons. The null hypothesis was supported.

\section{Research Question Five}

Research question five stated: Is there a relationship between certain student demographic variables (i.e., gender, ethnicity, full-time/part-time status, age, classification, generational status, and GPA) and student preference for advising style? The null hypothesis for this question stated student demographic variables (gender, age, classification, status, ethnicity, and generational status) are not related to student preference for advising style. 
A standard multiple regression was conducted to determine which independent variables (gender, age, classification, status, non-White, first-generation status, and GPA) were the predictors of student preference for academic advising style. Results (Table 11) indicate an overall model of two predictors (classification and GPA) that significantly predict student preference for advising style, $R^{2}=.079, F(260,267)=3.166, p=.003$. The model accounts for $7.9 \%$ of variance in student preference for advising style.

Table 11

Regression of Student Preference on Selected Sociodemographic Variables

\begin{tabular}{|c|c|c|c|c|c|c|}
\hline & & $\begin{array}{r}\text { Coe } \\
\text { Unsta } \\
\text { Coe } \\
\end{array}$ & $\begin{array}{l}\text { icients }^{\mathrm{a}} \\
\text { lardized } \\
\text { icients }\end{array}$ & $\begin{array}{c}\text { Standardized } \\
\text { Coefficients }\end{array}$ & & \\
\hline & & B & Std. Error & Beta & $t$ & Sig. \\
\hline 1 & (Constant) & 65.266 & 12.034 & & 5.424 & .000 \\
\hline & gender & -.245 & 2.807 & -.005 & -.087 & .931 \\
\hline & age & 1.191 & 3.134 & .028 & .380 & .704 \\
\hline & classification & 2.691 & 1.196 & .151 & 2.250 & .025 \\
\hline & status (full-/part-time) & 7.074 & 3.855 & .130 & 1.835 & .068 \\
\hline & non-White & -6.395 & 3.725 & -.107 & -1.717 & .087 \\
\hline & First Generation Student & .769 & 2.529 & .019 & .304 & .761 \\
\hline & GPA & -3.085 & 1.193 & -.160 & -2.587 & .010 \\
\hline
\end{tabular}

a. Dependent Variable: preferred advising style

A cross tabulation was used (Table 12) to compare the type of advising students preferred by the type of advising they received. A variable called "mismatch" was created to indicate whether the advising style students preferred and the style they received differed. A significant difference was found $\left(\chi^{2}(1, n=281), p=.000\right)$. Differences existed both for students who preferred prescriptive (40) and received developmental (13) advising and for students who preferred developmental (241) advising but received prescriptive (36) advising. The null hypothesis was not supported. 
Table 12

Crosstabulation - Mismatch of Student Preferred Advising Style by Advising Style Received

\begin{tabular}{cllrrr}
\hline & & \multicolumn{3}{c}{ Advising Style Received } & \\
\cline { 3 - 4 } & & Prescriptive & Developmental & Total \\
\hline Preferred & Prescriptive & Count & 27 & 13 & 40 \\
Advising & & $\%$ within Mismatch & $42.9 \%$ & $6.0 \%$ & $14.2 \%$ \\
Style & Developmental & Count & 36 & 205 & 241 \\
& & $\%$ within Mismatch & $57.1 \%$ & $94.0 \%$ & $85.8 \%$ \\
Total & & Count & 63 & 218 & 281 \\
& & $\%$ within Mismatch & $100.0 \%$ & $100.0 \%$ & $100.0 \%$ \\
\hline
\end{tabular}

$\chi^{2}(1, n=281), p=.000$

Mismatch (DV) was compared to college, gender, and GPA. No significant differences were found. In other comparisons, college, gender, GPA, and generational status were compared to mismatch (IV), also resulting in no significant differences.

An additional Cross Table using mismatch as the independent variable related to student responses to the five satisfaction statements. Students were asked to respond on a 4-point Likert-type scale anchored with 1 (strongly disagree) and 4 (strongly agree).

Significant differences were found on all five statements $\left(\chi^{2}(3, n=279), p=.000\right)$ indicating that receiving a style of advising different from the style preferred affected student satisfaction with advising. Tables 13-17 show the results.

Table 13

Crosstabulation - Satisfaction Statement One by Mismatch

\begin{tabular}{clrrr}
\hline & & \multicolumn{2}{c}{$\begin{array}{c}\text { Did students receive the advising } \\
\text { they wanted? }\end{array}$} \\
\cline { 3 - 5 } & & \multicolumn{1}{c}{ Yes } & \multicolumn{1}{c}{ No } \\
\hline \multirow{2}{*}{$\begin{array}{c}\text { I am Satisfied in General } \\
\text { with the Academic } \\
\begin{array}{c}\text { Advising I Have } \\
\text { Received }\end{array}\end{array}$} & $\begin{array}{l}\text { Strongly Disagree } \\
\text { Disagree }\end{array}$ & Count (\%) & $5(2.2 \%)$ & $7(14.3 \%)$ \\
& Agree & Count $(\%)$ & $18(7.8 \%)$ & $11(22.4 \%)$ \\
Total & Strongly Agree & Count $(\%)$ & $90(39.1 \%)$ & $25(51.0 \%)$ \\
\hline$\chi^{2}(3, n=279), p=.000$ & & & $230(100.0 \%)$ & $49(100.0 \%)$ \\
\hline
\end{tabular}


Table 14

Crosstabulation - Satisfaction Statement Two by Mismatch

Did students receive the advising they wanted?

\begin{tabular}{|c|c|c|c|c|}
\hline & & & \\
\hline & & & Yes & No \\
\hline \multirow{4}{*}{$\begin{array}{l}\text { I Have Received Accurate } \\
\text { Information About } \\
\text { Courses, Programs, and } \\
\text { Requirements Through } \\
\text { Academic Advising }\end{array}$} & Strongly Disagree & Count $(\%)$ & $5(2.2 \%)$ & $4(8.2 \%)$ \\
\hline & Disagree & Count $(\%)$ & $12(5.2 \%)$ & $13(26.5 \%)$ \\
\hline & Agree & Count $(\%)$ & $87(37.8 \%)$ & $23(46.90 \%)$ \\
\hline & Strongly Agree & Count (\%) & $126(54.8 \%)$ & $9(18.4 \%)$ \\
\hline Total & & & $230(100.0 \%)$ & $49(100.0 \%)$ \\
\hline
\end{tabular}

Table 15

Crosstabulation - Satisfaction Statement Three by Mismatch

Did students receive the advising they wanted?

\begin{tabular}{clrrr} 
& & & \multicolumn{1}{c}{ Yes } & \multicolumn{1}{c}{ No } \\
\cline { 3 - 4 } Sufficient Prior Notice & Strongly Disagree & Count (\%) & $7(3.0 \%)$ & $4(8.2 \%)$ \\
has been Provided about & Disagree & Count (\%) & $22(9.6 \%)$ & $12(24.5 \%)$ \\
$\begin{array}{c}\text { Deadlines Related to } \\
\text { Institutional Policies }\end{array}$ & Agree & Count (\%) & $87(37.8 \%)$ & $25(51.0 \%)$ \\
& Strongly Agree & Count (\%) & $114(49.6 \%)$ & $8(16.3 \%)$ \\
Total & & & $230(100.0 \%)$ & $49(100.0 \%)$ \\
\hline
\end{tabular}

$\chi^{2}(3, n=279), p=.000$

Table 16

Crosstabulation - Satisfaction Statement Four by Mismatch

Did student receive the advising they wanted?

\begin{tabular}{|c|c|c|c|c|}
\hline & & & \\
\hline & & & Yes & No \\
\hline \multirow{4}{*}{$\begin{array}{l}\text { Advising has been } \\
\text { Available When I } \\
\text { Needed it }\end{array}$} & Strongly Disagree & Count $(\%)$ & $2(.9 \%)$ & $3(1.8 \%)$ \\
\hline & Disagree & Count $(\%)$ & $9(3.9 \%)$ & $8(16.3 \%)$ \\
\hline & Agree & Count $(\%)$ & $86(37.4 \%)$ & $26(53.1 \%)$ \\
\hline & Strongly Agree & Count $(\%)$ & $133(57.8 \%)$ & $12(24.5 \%)$ \\
\hline Total & & & $230(100.0 \%)$ & $49(100.0 \%)$ \\
\hline
\end{tabular}

$\chi^{2}(3, n=279), p=.000$ 
Table 17

Crosstabulation - Satisfaction Statement Five by Mismatch

Did student receive the advising they wanted?

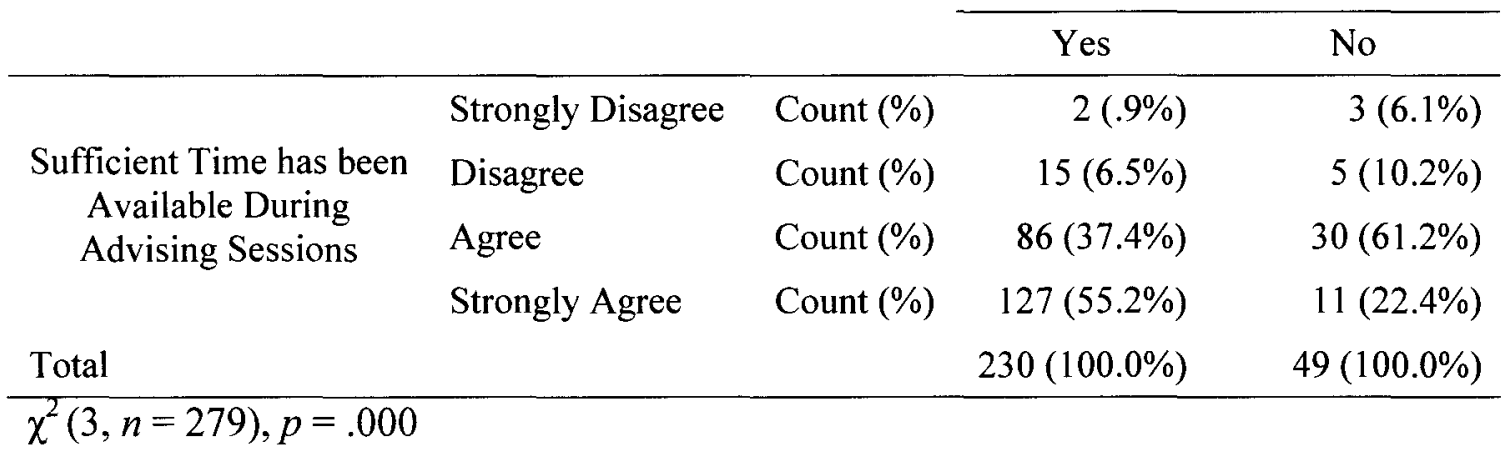

\section{Research Question Six}

Research question six stated: Is there a relationship between certain advisor demographic variables (i.e., age, gender, type, college) and advisor preference for advising style? The null hypothesis for this question stated that advisor demographic variables (type, age, gender, college) are not related to advisor preference for advising style delivery.

One-way Analysis of Variance (ANOVA) was used to examine differences between advisors' advising style delivery preference and these variables (age, gender, type, college, years as advisor on campus, and years as advisor overall). No significant relationship was found for age, college, years advising on campus, and years advising overall. A significant difference was found by gender $(F(1,39)=4.635, p=.038)$ and by advisor type $(F(1,39)=8.360, p=.006)$; therefore, the null hypothesis was not supported. Table 18 displays the results of advising style preference by gender and Table 19 displays the results of preference by advisor type. 
Table 18

Analysis of Variance - Advising Style Delivery Preference by Advisor Gender

\begin{tabular}{llllll}
\hline & Sum of Squares & df & Mean Square & F & Sig. \\
\hline Between Groups & 1085.400 & 1 & 1085.400 & 4.635 & .038 \\
Within Groups & 9133.722 & 39 & 234.198 & & \\
Total & 10219.122 & 40 & & & \\
\hline$F(1,39)=4.635, p=.038$ & & & &
\end{tabular}

Table 19

Analysis of Variance - Advising Style Preference by Advisor Type

\begin{tabular}{llllll}
\hline & Sum of Squares & df & Mean Square & F & Sig. \\
\hline Between Groups & 1803.824 & 1 & 1083.824 & 8.360 & .006 \\
Within Groups & 8415.298 & 39 & 215.777 & & \\
Total & 10219.122 & 40 & & & \\
\hline$F(1,39)=8.360, p=.006$ & & & &
\end{tabular}

\section{Summary}

The results presented in Tables 1-17 clearly indicate incongruence for some student respondent preferences for advising style as compared to advisor preferences. Moreover, preference for a particular advising style was found to relate to certain student and advisor demographic variables. A more detailed summary and a discussion of the findings are presented in the next chapter. 


\section{CHAPTER V}

\section{DISCUSSION AND CONCLUSION}

Retention and graduation of college students means more than just economics to institutions of higher education. National urgency to remain globally competitive, in both education and in business, highlights the need to graduate more students, creating expectations for states to produce more graduates. According to Lee and Rawls (2010), as of 2007 only $56.1 \%$ of students who entered an institution of higher education intent on earning a bachelor's degree persisted to graduate within six years or less. In Kentucky only $47.3 \%$ met that goal.

The literature has shown that students satisfied with their college experience are more likely to be retained and to graduate (e.g., Guinn \& Mitchell, 1986; Hornbuckle, Mahoney, \& Borgard, 1979; McAnulty, O'Connor, \& Sklare, 1987; McLaughlin \& Starr, 1982; Stickle, 1982; Vowell \& Karst, 1987). Studies also have related that students may base satisfaction with the college experience on the services provided by their institution (Light, 2001; Tinto, 1993). One service provided at each institution in Kentucky is academic advising.

Developmental and prescriptive advising are the two best-known and most often used approaches to academic advising. Developmental advising focuses on advising as a form of teaching and it focuses on student development. With prescriptive advising, advisors prescribe remedies and students follow the advice. The literature provides 
examples of students who prefer developmental advising and those who prefer prescriptive advising. Few studies, however, provide a definitive basis for whether advising should be expressly one style or the other. Though advising style and advising delivery systems may vary across campus, it is important that both students and their advisors, whether faculty or professional staff, understand the purpose of advising and that what advisors perceive they deliver is what students perceive they receive.

\section{Summary of the Study}

Completed survey responses were received from two groups. Faculty and professional academic advisors $(N=42)$ actively advising during the spring 2012 semester were one group of respondents. The second group was the students $(N=300)$ assigned to those advisors. Advisors and students both completed the Winston and Sandor (1984b) Academic Advising Inventory (AAI). Demographic and academic information was self-reported.

Based on response rates, the results of this study cannot be generalized to either the advisor population or the student population. Statistically significant information relates only to the advisors and students who responded to the survey.

A standard multiple regression, one-way ANOVA, bivariate analysis, and a difference of proportions test were used to answer these six research questions:

1. Do students prefer developmental or prescriptive advising?

2. Do advisors prefer developmental or prescriptive advising?

3. Does student preference differ by college and/or department?

4. By college and/or department, do student and advisor preferences match? 
5. Is there a relationship between certain student demographic variables (i.e., gender, ethnicity, age, classification, generational status, and GPA) and student preference for advising style?

6. Is there a relationship between certain advisor demographic variables (i.e., age, gender, and advisor type) and advisor preference for advising style?

In the multiple regression, these independent variables (gender, age, classification, status, non-White, first-generation status, and GPA) were the predictors of student preference for academic advising style. The difference of the proportions test was performed with the null hypothesis being no difference between student and advisor preferences in advising. The z-score testing this hypothesis was $9.36(p<.001)$. ANOVA was used to examine differences between advisors' advising style delivery preference and these variables (age, gender, type, college, years as advisor on campus, and years as advisor overall).

Bivariate analysis was used only for student responses. Student predictor variables included father's education level, mother's education level, generational status, gender, age, college, classification, status, race, and non-White. Cross Tables require two variables; and because all advisors rated the advising they provided and the advising the preferred as developmental, it could not be used for analysis of advisors.

Descriptive statistics were used to answer research questions one and two. Cross Tables were used for research question three. The difference of proportions test was used to answer research question four. Multiple regression was used to answer research question five, and ANOVA was used to examine research question six. 


\section{Discussion and Implications}

To provide a more concise discussion of the results of this study, information and findings related to advisors will be discussed first. Research questions two and six relate specifically to advisors. Information and findings related to students will follow the advisor information. Research questions one, three, and five relate to students. Last will be a discussion of the advisor and student preference comparisons (research question four).

\section{Advisors}

Research question two asked whether advisors preferred developmental or prescriptive advising. All advisors (42) reported that they preferred developmental advising. Demand characteristics may have played a role in the finding that all responding advisors preferred to deliver developmental advising. Orne (1962) stated that researchers provide clues to subjects that can determine behavior. Clues also may appear in everyday life. For example, when advisors responded to the AAI, they might have provided answers based on experiences they have had with advising, on discussions they have had with other advisors or faculty related to advising, or on their perceptions of what might be considered socially desirable responses. Advisors also may have chosen the answer that they believed placed them in what they perceived as the best or most favored category. Saving and Keim (1998) reported that advisors in their study also selfreported that they developmentally advised.

According to Winston and Sandor (2002), scores on the Academic Advising Inventory (AAI) range from 14-112. Scores from 14-56 indicate a prescriptive relationship in advising; one characterized as authoritative and with the advisor 
functioning as the expert. Scores ranging from 57-112 indicate a more developmental relationship. In the developmental relationship the advisor and student "have established a warm, caring, and friendly relationship" (p. 11) and they work together to decide which responsibilities belong to the advisor and which to the student. The advisor and student work together to help the student reach his or her potential by using all available resources on a campus.

The range of the continuum suggests that both prescriptive advising and developmental advising have degrees of strength, but still measures advising as two distinct styles. For example, if the highest possible scale mark is 112 , then an advisor with a 112 has self-rated as more often adopting a developmental approach than the advisor with a lower score (i.e., 60) on the continuum. The reverse also holds true. An advisor at the 56 mark on the scale is considered prescriptive like the advisor at the 14 mark. The advisor at the 56 mark, though, has identified some areas where he/she provides a more developmental advising approach. Smith and Allen (2006) stated that measuring advising with a dichotomized approach does not allow respondents to indicate that both prescriptive and developmental advising play an important role in advising students.

A review of the frequencies on the advisor developmental scale related to preferred advising style shows that the low score was 60 and the high was 112 . On advising style provided, the low score was 57 and the high score was 109 . There was variability in the differences in the scores. One score dropped by 10 points, one increased by 30 , and only three remained unchanged. The three scales are included as Appendices $\mathrm{C}, \mathrm{D}$, and $\mathrm{E}$. 
Research question six asked whether advisor demographic variables related to advisor preference for advising style. Cross Tables could not be calculated for advisors since they all rated their preference as developmental. A low response rate prevented the use of multiple regressions to analyze advisor data. One-way Analysis of Variance allows the examination of the effect one factor has on a dependent variable and was used to examine these variables (age, gender, type, college, years advising on campus, and years advising overall). Post hoc analysis was done with the Scheffé post hoc test. ANOVAs were calculated for preferred advising style and for the style advisors delivered to students.

An ANOVA was used to analyze preferred advising delivery style by advisor type. A significant difference was found in preference for advising style $(F(1,39)=8.360, p=.006)$ and in the style of advising provided to students $(F(1,39)=5.174, p=.029)$. Professional advisors appear to have higher developmental scores in their preference $(M=101.44, S D=9.50)$ and in delivery $(M=89.71$, $S D=9.30)$ than faculty advisors $(M=87.84, S D=17.15$, and $80.71, S D=14.28$, respectively).

Differences in the scores by advisor type could relate to several factors. Workload varies for faculty and for professional advisors. Lynch and Stucky (2000), for example, related that where faculty advisors spend about $24 \%$ of their time on advising and the remainder on teaching, research, and departmental, college, and university duties, professional advisors spend about $80 \%$ of their time advising. Professional advisors also may have a background in student affairs or have more advising training than faculty advisors (Kelly, 1995; King, 1993). Shields and Gillard (2002) related the influx of more 
professional advisors to the size of school, with larger schools having more professional advisors. Kelly (1995) attributed the growth of professional advisors to the everincreasing student populations.

An ANOVA to examine advising style preference by advisor gender showed significant results $(F(1,39)=4.635, p=.038)$. Female advisors $(M=95.88, S D=15.37)$ had higher developmental scores than did male advisors $(M=83.44, S D=15.06)$. Kaplan (1994) stated that women's psychological development helps make them caretakers. Males are often more action- or solution-focused (Wester \& Vogel, 2002) than women. The ANOVA used to examine advising style delivered by gender was not significant.

Advisor age did not affect advising style preference. The lowest mean score related to advisors in the 65 years and over $(M=76, S D=5.66)$ age group. The highest score relates to those advisors in the 22 to 34 year age range $(M=99.8, S D=12.28)$. The delivery of advising by age reflects the same pattern. The lowest mean score related to the advisors in the 65 years and over age group $(M=78, S D=11.31)$ and the group with the highest developmental score were the advisors in the 22 to 34 year age range $(M=89.6, S D=10.33)$. Such a pattern might be emerging due to more professional advisors emerging from counseling and student affairs fields.

There was no effect on preference of advising style by college. The PCAL had the lowest mean score $(M=99.17, S D=10.82)$, followed by CHHS $(M=90.92$, $S D=20.52)$, the UC $(M=91.44, S D=16.58)$, and the OCSE $(M=95, S D=20.66)$. The GFCB was second highest $(M=100.00, S D=2.94)$, and the CEBS had the highest developmental mean $(M=104.00, S D=8.16)$. Advising style provided to students 
resulted in a similar structure with CHHS having the lowest mean score $(M=78.54)$, followed by PCAL $(M=8.18, S D=14.79)$, the UC $(M=83.44, S D=14.68)$, and the OCSE $(M=91.33, S D=18.90)$. The CEBS had the second lowest mean score $(M=91.6, S D=10.26)$, and the GFCB had the highest mean scores $(M=92, S D=$ 4.24).

An analysis of advisor preference and delivery style by years as an advisor on campus revealed that advisors in the 11 to 15 year range had the lowest mean scores on both the preference $(M=81.14, S D=14.08)$ and delivery of developmental advising $(M=77.29, S D=14.53)$. The analysis of years as an advisor overall showed a similar result. Advisors in the 11 to 15 year range had the lowest mean scores on the preferred developmental scale $(M=88.5, S D=19.26)$ and on the delivered scale $(M=81.11, S D$ $=13.58)$.

Advisors were asked to answer five satisfaction questions on a 4-point Likert-type scale anchored with 1 (strongly disagree) and 4 (strongly agree). Advisors were satisfied with the advising they provided $(M=3.45, S D=.504)$ and believed they provided accurate information about courses, programs, and requirements $(M=3.67, S D=.477)$. Though they believed advising was valued in their college $(M=3.31, S D=.715)$, they were less satisfied with the time available for advising sessions $(M=2.95, S D=7.31)$ and least satisfied with advising being considered in faculty tenure guidelines $(M=2.67$, $S D=1.1)$

\section{Students}

Research question one asked whether students preferred developmental or prescriptive advising, and the fourth research question asked whether student and advisor 
preferences matched by college. Since all advisors indicated they preferred developmental advising, both research questions are answered below.

Sixty-nine students (23\%) preferred prescriptive advising, and 226 students (75.3\%) preferred developmental advising. The mean for student preference for advising $(M=81.08, S D=20.21)$ indicated an overall preference for developmental advising. Considering that $32.5 \%$ of students who preferred prescriptive advising (40) received developmental advising (13) is important. Additionally, 36 students $(12.8 \%)$ who preferred developmental advising received prescriptive advising.

Demand characteristics also may have influenced student responses. Orne (1962) pointed out that perceived demand characteristics may vary by respondent. The previous experience of advisors may establish a different set of clues from which advisors responded to the AAI than the clues students may use. Student ratings of advisors were generally lower than the self-ratings of advisors. Such a difference is not uncommon in the advising literature (Allen \& Smith, 2008; Saving \& Keim, 1998; Stickle, 1982).

The third research question asked whether student preferences differed by college and/or department. Bivariate analysis was used to analyze whether college choice affected student preference for developmental or prescriptive advising. No significant results were found; however, every college had students who preferred both prescriptive advising and developmental advising.

The AARC has the lowest percentage of students who preferred developmental advising (77.8\%), and OCSE had the highest percentage (95\%). The CHHS had the highest percentage of students (22.9\%) who preferred prescriptive advising. The CEBS 
has the lowest percentage of students indicating they preferred prescriptive advising $(1.3 \%)$

Students advised in the AARC are generally exploratory students. The students may be involved in special programming based on, for example, ACT scores or on current academic standing as measured by GPA. Those students receive assistance from a professional staff program director, from peer advisors, and from an academic advisor. They may indicate a preference for prescriptive advising because they are overloaded with advising-type connections in the requirements associated with special programming. Students in the CHHS may have related more positively to prescriptive advising because their programming (i.e., nursing, dental hygiene) may follow lock-step courses for a cohort of students. They may find prescriptive advising particularly helpful. As mentioned earlier, students who receive a particular style of advising may indicate a preference for that style (Mottarella et al., 2004).

Bivariate analysis examining advising received by college resulted in significant findings indicating that differences existed $\left(\chi^{2}(6, n=286), p=.000\right)$. More than $50 \%$ of students $(55.6 \%)$ in the AARC indicated they received developmental advising, much lower than the percentage that preferred developmental advising $(77.8 \%)$. In the OCSE, $85.7 \%$ reported receiving developmental advising though $95 \%$ indicated it as a preference. Of the CHHS respondents, $41.7 \%$ indicated they received prescriptive advising, higher than the $22.9 \%$ who preferred it. In the CEBS $1.3 \%$ of respondents indicated they would prefer prescriptive advising, and $37.3 \%$ indicated that they received it. 
Research question five asked whether there was a relationship between certain student demographic variables (i.e., gender, ethnicity, age, classification, generational status, and GPA) and student preference for advising style. A standard multiple regression was conducted to determine which independent variables (gender, age, classification, status, non-White, first-generation status, and GPA) were the predictors of student preference for academic advising style. Results (Table 11) indicated an overall model of two predictors (classification and GPA) that significantly predicted student preference for advising style.

The regression model accounted for $7.9 \%$ of variance in student preference for advising style. The relationship between student classification and advising style preference indicated that, for each level change (i.e., freshman to sophomore), student preference for developmental advising increased. For each unit of increase in student GPA, the score on the developmental continuum moved toward the prescriptive end of the scale. In other words, as GPA increased, student preference for developmental advising decreased. It appears that students with higher GPAs may prefer a less personal relationship with advisors, while students with lower GPAs may prefer a more personal relationship.

Bivariate analysis was used to examine the student variables (gender, ethnicity, age, classification, generational status, and GPA) based on the advising students received. Significant results were found on three variables; gender $\left(\chi^{2}(1, n=293), p=.031\right)$, classification $\left(\chi^{2}(4, n=294), p=.043\right)$, and non-White $\left(\chi^{2}(1, n=272), p=.013\right)$.

By gender, more females (26.9\%) indicated receiving prescriptive advising than did males (14.8\%). By student classification, $27.8 \%$ of freshmen (10) reported receiving 
prescriptive advising. Sixteen sophomores (31.4\%), 14 juniors (15.9\%), 20 seniors (20.4\%), and 9 others (42.9\%) also reported receiving prescriptive advising. By nonWhite, $33.3 \%$ of Black/African Americans, $50 \%$ of Asians, $40 \%$ of Hispanics, $22.3 \%$ of Whites, and $50 \%$ of students reporting two or more races reported receiving prescriptive advising.

Student age did not affect preference for advising or advising received. Twentyfive students aged older than 25 years $(25 \%)$ indicated that they received prescriptive advising, and 44 traditionally aged students (22.7\%) indicated receiving prescriptive advising. Non-traditional students may find it harder to fit advising into their lives. They may have work experience and be more independent than traditional students (Giancola, Munz, \& Trares, 2008). Older students also may have less need for someone to give them information (Andrews, Andrews, Long, \& Henton, 1987)

Student status (full-time/part-time) did not affect preference for advising or advising received. The Cross Table used to examine advising received by status revealed that $21.3 \%$ of part-time students received prescriptive advising as did $23.9 \%$ of full-time students.

An ANOVA and bivariate analyses were used to examine student preference for advising by student classification (freshman, sophomore, junior, and senior). No significant difference was found with either test. Five freshmen (14.7\%) preferred prescriptive advising, as did nine sophomores (18.4\%), 10 juniors (11.5\%), 11 seniors (11.8\%), and 5 students (23.8\%) classified as "other." "Other" students include post baccalaureate degree seeking, students seeking certification, and those who are nondegree seeking. 
Bivariate analysis was used to examine advising received by student Grade Point Average (GPA). No significant difference was found. Forty students (14.1\%) preferred prescriptive advising, and $23 \%$ of all students (69) reported receiving it.

First-generation status, as measured by a combination of mother's education level and father's education level, did not affect preference for advising or advising received. At the institution under study, having first-generation status means that either parent may have attended some college but neither may have graduated. Twenty first-generation students (14.1\%) and 18 continuing-generation students (12.9\%) preferred prescriptive advising. The Cross Table of advising received by first-generation students indicated that 30 first-generation students (20.7\%) and 38 continuing-generation students (26\%) received prescriptive advising.

\section{Student Satisfaction}

Bivariate analysis was used to evaluate student responses to five satisfaction statements. First, satisfaction was tested by mismatch (students did not receive the advising style they preferred). Second, satisfaction was tested by mismatch and by student classification. Classification was combined into two variables - Lower Class and Upper Class students. Lower class students were freshmen and sophomores. Upper Class students were juniors and seniors. In both instances significant results were found $\left(\chi^{2}(3, n=279), p=.000\right)$, indicating that the style of advising received effected student satisfaction.

In the comparison of satisfaction by mismatch by class, Lower Class responses were not significant on two satisfaction statements but the overall response remained significant at the .000 level. The first statement was, "I have received accurate 
information about courses, programs, and requirements through academic advising." The second statement was, "Sufficient time has been available during advising sessions."

Although most students reported satisfaction with advising, 8.4\% were not satisfied with advising in general; $16 \%$ did not think sufficient prior notice had been provided about deadlines related to institutional policies and procedures; and $8.9 \%$ did not believe they had received accurate information about courses, program, and requirements through academic advising. Other respondents (8.4\%) did not agree that advising was available when they needed it, and $9 \%$ did not think sufficient time was available during advising appointments.

Although the data in this study are not generalizable to the larger population, they do suggest that there is a population of students who are not receiving the advising they would prefer. That incongruence can lead to lower levels of satisfaction and could affect retention.

\section{Limitations of the Study}

The low response rate in the present study limits generalizability. A confluence of issues may have contributed to the reduced rates. The timing for human subjects approval from two institutions resulted in the survey being sent to faculty advisors and advisors just before the institution's spring break. The survey was sent via email and; for some faculty and advisors who took the week off, overloaded email boxes may have caused them to overlook or decide to eliminate the survey from their inbox.

Issue two relates to a problem with advisor respondent emails that could not be captured. The original survey had to be closed and a new invitation to participate was sent. Sixty-seven people had already responded to the first survey; 55 responded to the 
second invitation. Student surveys were sent out as advisors responded to the survey, and a reminder email was sent to both advisors and to students.

Survey fatigue is possibly another reason for low response rates. Porter, Whitcomb, and Weitzer (2004) said that survey fatigue and the associated drops in response rates relate to growth in technology and the lower cost of sending surveys. They stated that college students were receiving surveys from national agencies, colleges, institutional research offices, departments, faculty, and even other students. An additional issue may be not only the number of surveys students receive, but also the timing. Two surveys may overlap and students make a choice to answer one but not the other.

Lipka (2011) related survey fatigue as the biggest reason for increasing nonresponse rates and discussed adding incentives to improve rates. Sending incentives electronically can be challenging, but she related that some response rates improved with an electronic coupon. Dillman (2000) also mentioned using incentives to improve survey response rates. Faculty and students who were sent the invitation to participate in the current survey were offered an opportunity to enter their name into a drawing for one of three (total of six) Visa gift cards valued at $\$ 100, \$ 50$, and $\$ 25$. Twenty-nine advisors and 241.students entered the drawing.

Another limitation also might relate to the layout and length of the survey. The instructions may not have been stated clearly enough, especially for advisors. Though the survey took less than 20 minutes to complete, having to read the same series of 14 questions twice may have seemed tedious. The survey system shows, for example, that 525 students started the survey but only 310 completed it. 


\section{Conclusion and Suggestions for Future Research}

Although the findings of this study are not generalizable, they do suggest that some students may not be receiving the advising they prefer to receive. Such incongruence can lead to lower levels of satisfaction that, in turn, can affect retention rates.

It is important to consider, though, that not all students have the same needs. For example, a part-time student with a full-time job might find it difficult to make time to meet with an advisor. The student may have mapped out his/her progress so that the need to have a hold lifted becomes the sole purpose for the meeting. Advisors should be aware that those students may need an alternative approach to advising.

Several populations were overrepresented. For example, females and professional advisors were overrepresented (percentage wise) in the responses. All professional advisors on campus are female. The professional advisors may have a more personal stake in contributing to the research on advising, and the university has a campus-wide advising network that meets on a nearly monthly basis to share best-practices, of which, the researcher is a member.

The findings reported in this study indicate that there is a mismatch between the style of advising preferred and what is received by some students. Although students indicated overall satisfaction with advising, when a mismatch occurred the effect on satisfaction was significant $\left(\chi^{2}(3, n=279), p=.000\right)$. Examining student understanding and expectations of advising might help reduce the incongruence. The literature supports that advising impacts retention. When a mismatch does occur, it could negatively impact retention and may unduly influence student perceptions of the value of advising. 
Future advising research on campus might include interviews and/or focus groups. By gathering information in respondents' words, researchers can develop insight into how something as complex as advising may be interpreted. Focus groups, according to Bogdan and Biklen (2003), are often used by evaluation and policy researchers regarding responses to institutional interventions. Focus groups provide structured group interviews designed to encourage a conversation among the participants that will identify issues.

Asking a series of the same questions to students and advisors might uncover differences between the groups that cannot be measured by an instrument like the AAI. Holding focus groups of both populations could help define how each group views advising. The results from the focus groups and interviews may allow for the creation of an advising survey that would more accurately measure advising on a campus.

Developmental advising is an attractive option for advisors. Faculty and advisors are in the business of helping students navigate college, and both groups provide a different touch-point for students. Providing only developmental advising is not practical. There are certain standards, deadlines, and requirements of which students must be made aware, and prescriptive advising provides the means for students to receive that information.

The AAI was chosen for this study because it has been reported numerous times in the literature as particularly appropriate for assessing advising at a single institution. However, some of the difficulties experienced with the AAI in the present study suggest that additional research may be needed on the AAI as utilized in this study. 
An analysis of advisor and student responses revealed that many respondents completed the first 14 questions, responded to the satisfaction statements, provided the demographic information, and quit the survey when they reached Part IV and the repeat of the 14 questions. That is, the procedure may have seemed too burdensome for some potential participants and thereby led to reduced participation. In addition, the wording of the instructions may not have been clear for advisors, as they had to mentally consider how they preferred to provide or how they provided advising to students 28 different times.

Thus, future researchers may want to consider using a different instrument. Allen and Smith (2006) stated that an instrument that defines advisement as a dichotomized variable may prevent student respondents from expressing that both advising styles play an important role. Fielstein (1994) posited that dichotomous measurements fail to allow students to judge independently the importance of both styles.

Other than using a different survey instrument, future studies also might use smaller samples and fewer variables. The current study may have taken on too large a population (the entire undergraduate advisor and student population). For example, a college (and not university-wide) mixed-mode or paper survey of students to investigate the style of advising they prefer for only one college might yield better results and provide that college with a tool to begin changing advising for the better. 


\section{REFERENCES}

Afshar, T., \& O'Hara, L. (2006). Pedagogical issues concerning academic advising. Journal of College Teaching and Learning, 3(10), 25-44.

Agresti, A., \& Finlay, B. (1986). Statistical methods for the social sciences. San Francisco: Dellen Publishing Company.

Alexitch, L. (1997). Students' educational orientation and preferences for advising from university professors. Journal of College Student Development, 38, 333-343.

Allen, J., \& Smith, C. (2008). Importance of, responsibility for, and satisfaction with academic advising: A faculty perspective. Journal of College Student Development, 49, 397-411. doi: 10.1353/csd.0.0033

Andrews, M., Andrews, D., Long, E., \& Henton, J. (1987). Student characteristics as predictors of perceived academic advising needs. Journal of College Student Personnel, 28, 60-65.

Bai, H., \& Pan, W. (2009). A multilevel approach to assessing the interaction effects on college student retention. Journal of College Retention, 11(2), 287-301.

Barry, L., Hudley, C., Kelly, M., \& Cho, S. (2009). Differences in self-reported disclosure of college experiences by first-generation college student status. Adolescence, 44(173), 55-68.

Beasley-Fielstein, L. (1986). Student perceptions of the developmental advisor-advisee relationship. NACADA Journal, 6(2), 107-117. 
Belcheir, M. (1998). Student satisfaction with academic advising (98-04). Boise State University, Office of Institutional Assessment Research Report. Retrieved from http://www.eric.ed.gov/contentdelivery/servlet/ERICServlet?accno=ED423806

Berdahl, R. (1995). Educating the whole person. New Directions for Teaching and Learning, 62, 5-11.

Bickman, L., \& Rog, D. (1998). Handbook of applied social research methods. Thousand Oaks, CA: Sage Publications, Inc.

Biggs, D., Brodie, J., \& Barnhart, W. (1975). The dynamics of undergraduate advising. Research in Higher Education, 3, 345-357. doi: 10.1007/BF00991251

Bogdan, R., \& Biklen, S. (2003). Qualitative research for education: An introduction to theories and methods. Boston: Allyn and Bacon.

Briggs, K., \& Myers, I. (1983). Myers-Briggs Type Indicator, Form G. Palo Alto, CA: Consulting Psychologists Press, Inc.

Broadbridge, A. (1996). Academic advising - traditional or developmental approaches?: Student perspectives. British Journal of Guidance \& Counseling, 24(1), 97-112. Chickering, A., \& Project on Student Development in Small Colleges. (1969). Studentfaculty relationships: Bedrock for college governance. Retrieved from http://www.eric.ed.gov/contentdelivery/servlet/ERICServlet?accno=ED038910 Chickering, A. (1970). Civil liberties and the experience of college. Journal of Higher Education, 41, 599-606. doi: 10.2307/1977662

Chickering, A., \& Associates. (1981). The modern American college: Responding to the new realities of diverse students and a changing society. San Francisco: JosseyBass, Inc. 
Cook, C., Heath, F., \& Thompson, B. (2000). A new culture of assessment: Preliminary report on the ARL SERVQUAL survey. Proceedings of the IFLA Council and General Conference ( $66^{\text {th }}$, Jerusalem, Israel, August 13-18, 2000). Retrieved from http://www.eric.ed.gov/contentdelivery/servlet/ERICServlet?accno=ED450746

Costello, A., \& Osborne, J. (2005). Best practices in exploratory factor analysis: Four recommendations for getting the most from your analysis. Practical Assessment, Research \& Evaluation, 10(7). Available online: http://pareonline.net/getvn.asp? $v=10 \& n=7$

Creamer, D., \& Associates. (1990). College student development: Theory and practice for the 1990s. Washington, DC: American College Personnel Association.

Creamer, D. (2000). Use of theory in academic advising. In V. Gordon \& W. Habley (Eds.), Academic advising: A comprehensive handbook (pp. 18-34). San Francisco: Jossey-Bass.

Crockett, D. (1978). Academic advising: A comerstone of student retention. In L. Noel (Ed.), Reducing the dropout rate Volume 3 of New Directions for Student Services (pp. 29-35). San Francisco: Jossey-Bass.

Crockett, D. (1985). Academic advising. In L. Noel, R. Levitz, D. Saluri, \& Associates (Eds.), Increasing student retention (pp. 244-263). San Francisco: Jossey-Bass.

Crockett, J., \& Crawford, R. (1989). The relationship between Myers-Briggs Type Indicator (MBTI) scale scores and advising style preferences of college freshmen. Journal of College Student Development, 30(2), 154-161.

Crookston, B. (1994). A developmental view of academic advising as teaching, NACADA Journal, 14(2), 10-16. 
DeShields, O., Kara, A., \& Kaynak, E. (2005). Determinants of business student satisfaction and retention in higher education: Applying Herzberg's two-factor theory. International Journal of Educational Management, $19(2 \& 3), 128-139$. doi: $10.1108 / 09513540510582426$

Dillman, D. (2000). Mail and internet surveys: The tailored design method $\left(2^{\text {nd }}\right)$. New York: John Wiley \& Sons, Inc.

Dillman, D. (2006). Why choice of survey mode makes a difference. Public Health Reports, 121(1), 11-13.

Dillon, R., \& Fisher, B. (2000). Faculty as part of the advising equation: An inquiry into faculty viewpoints on advising. NACADA Journal, 20(1), 16-23.

Duggan, M., \& Pickering, J. (2008). Barriers to transfer student academic success and retention. Journal of College Student Retention, 9(4), 437-459. doi: $10.2190 / \mathrm{CS} .9 .4 . \mathrm{c}$

Ender, S. (1994). Impediments to developmental advising. NACADA Journal, 14(2), 105107.

Ender, S., Winston, R., Jr., \& Miller, T. (1982). Academic advising as student development. New Directions for Student Services: Developmental Approaches to Academic Advising, (pp. 3-18). San Francisco: Jossey-Bass.

Engle, J., \& Tinto, V. (2008). Moving beyond access: College success for low-income, first-generation students. Pell Institute for the Study of Opportunity in Higher Education. Retrieved from http://www.pellinstitute.org/downloads/publicationsMoving_Beyond_Access_2008.pdf 
Erikson, E. (1959). Identity and the life cycle: Selected papers. Oxford, England: International Universities Press.

Fielstein, L. (1987). Student preferences for personal contact in a student-faculty advising relationship. NACADA Journal, 7(2), 34-40.

Fielstein, L. (1989). Student priorities for academic advising: Do they want a personal relationship? NACADA Journal, 9(1), 33-38.

Fielstein, L. (1994). Developmental versus prescriptive advising: Must it be one or the other. NACADA Journal, 14(2), 76-79.

Fielstein, L., Scoles, M., \& Webb, K. (1992). Differences in traditional and nontraditional students' preferences for advising services and perceptions of services received. NACADA Journal, 12(2), 5-12.

Friedman, B., \& Mandel, R. (2009). The prediction of college student academic performance and retention: Application of expectancy and goal setting theories. Journal of College Student Retention, 11(2), 227-246.

Frost, S. (1991). Academic advising for student success: A system of shared responsibility (ASHE-ERIC Higher Education Report No. 3). Washington, DC: The George Washington University.

Frost, S. (2000). Historical and philosophic foundations for academic advising. In V. Gordon \& W. Habley (Eds.), Academic advising: A comprehensive handbook (pp. 3-17). San Francisco: Jossey-Bass.

Gardiner, L. (1998). Why we must change: The research evidence. The NEA Higher Education Journal, 14(1), 71-88. 
Giancola, J., Munz, D., \& Trares, S. (2008). First- versus continuing-generation adult students on college perceptions: Are differences actually because of demographic variance? Adult Education Quarterly, 58(3), 214-228.

Grimm, J., \& Wozniak, P. (1990). Basic social statistics and quantitative research methods. Belmont, CA: Wadsworth Publishing Company.

Grites, T. (1979). Academic advising: Getting us through the Eighties (AAHE/ERIC Higher Education Report No. 7). Washington, DC: American Association for Higher Education.

Grites, T. (1981). Being "undecided" might be the best decision they could make. School Counselor, 2(1), 41-46.

Guinn, D., \& Mitchell, R. (1986). Academic advising: And different expectations. NACADA Journal, 6(2), 99-105.

Habley, W. (1981). Academic advisement: The critical link in student retention. NASPA Journal, 18(4), 45-50.

Habley, W. (1994). Fire! (ready, aim): Is criticism of faculty advising warranted? NACADA Journal, 14(2), 25-31.

Habley, W. (1997). Organizational models and institutional advising practices. NACADA Journal, 17(2), 39-44.

Habley, W. (2004). The status of academic advising: Findings from the ACT sixth annual survey. National Academic Advising Association Monograph Series Number 10. Manhattan, KS: NACADA. 
Habley, W., \& McClanahan, R. (2004). What works in student retention? Iowa City, IA: ACT, Inc. Retrieved from http://act.org/research/policymakers/pdf/droptables/ AllColleges.pdf

Hale, M., Graham, D., \& Johnson, D. (2009). Are students more satisfied with academic advising when there is congruence between current and preferred advising styles? College Student Journal, 43(2), 313-324.

Hornbuckle, R., Mahoney, J., \& Borgard, J. (1979). A structural analysis of student perceptions of faculty advising. Journal of College Student Personnel, 20(4), 296300.

Kaplan, L. (1994). Woman as caretaker: An archetype that supports patriarchal militarism. Hypatia, 9(2), 123-133.

Kapraun, E., \& Coldren, D. (1980). An approach to the evaluation of academic advising. Journal of College Student Personnel, 21, 85-86.

Kelly, J. (1995). Faculty speak to advising. New Directions for Teaching and Learning, $62,13-24$

Kentucky Council on Postsecondary Education (2011). http://www.cpe.ky.gov/institutions/

Kentucky Postsecondary Education Improvement Act of 1997 (HB1), Ky. Stat. Ann. § 164.003(1b) (Amended 2008 Ky. Acts ch. 113, sec. 9, effective July 15, 2008. -Amended 2002 Ky. Acts ch. 37, sec. 2, effective July 15, 2002. -- Amended 2000 Ky. Acts ch. 526, sec. 2, effective July 14, 2000. -- Created 1997 (1st Extra. Sess.) Ky. Acts ch. 1, sec. 2, effective May 30, 1997). 
King, M. (1993). Academic advising: Organizing and delivering services for student success. New Directions for Community Colleges, 1993(82), 21-31.

Kiser, A., \& Price, L. (2008). The persistence of college students from their freshman to sophomore year. Journal of College Student Retention, 9(4), 421-436. doi: $10.2190 / \mathrm{CS} .9 .4 . \mathrm{b}$

Kohlberg, L. (1964). Development of moral character and moral ideology. In M. Hoffman \& L. Hoffman (Eds.), Review of child development research (pp. 383431). New York: Russell Sage Foundation.

Larsen, M., \& Brown, B. (1983). Student and faculty expectations of academic advising. NACADA Journal, 3(1), 31-37.

Lee, J., \& Rawls, A. (2010). The college completion agenda: 2010 progress report. New York: College Board Advocacy \& Policy Center. Retrieved from http://www.collegeboard.org/

Light, R. (2001). Making the most of college: Students speak their minds. Cambridge, MA: Harvard University Press.

Lipka, S. (2011). Want data? Ask students. Again and Again. Chronicle of Higher Education, 57(43), pA1-A6.

Lohfink, M., \& Paulsen, M. (2005). Comparing the determinants of persistence for firstgeneration and continuing-generation students. Journal of College Student Development, 46, 409-428. doi: 10.1353/csd.2005.004

Lowe, A., \& Toney, M. (2000). Academic advising: Views of the givers and takers. Journal of College Student Retention, 2(2), 93-108. 
Lynch, M. (2004). A survey of undergraduate student reactions to academic advising. NACADA Journal, 24(1 \& 2), 62-74.

Lynch, M., \& Stucky, K. (2000). Advising at the millennium: Advisor roles and responsibilities. NACADA Journal, 21(1 \& 2), 15-31.

McAnulty, B., O'Connor, C., \& Sklare, L. (1987). Analysis of student and faculty opinion of academic advising services. NADACA Journal, 7(1), 49-61.

McLaughlin, B., \& Starr, E. (1982). Academic advising literature since 1965: A college student personnel abstracts review. NACADA Journal, 2(2), 14-23.

Mertler, C., \& Vannatta, R. (2005). Advanced and multivariate statistical methods: Practical application and interpretation. Glendale, CA: Pyrczak Publishing.

Milem, J., Berger, J., \& Dey, E. (2000). Faculty time allocation: A study of change over 20 years. Journal of Higher Education, 71, 454-475. doi: 10.2307/2649148

Miller, T., Binder, B., Schuh, J., \& Associates. (2005). Promoting reasonable expectations: Aligning student and institutional views of the college experience. San Francisco: Jossey-Bass.

Miller, T., Kuh, G., Paine, D., \& Associates. (2006). Taking student expectations seriously: A guide for campus applications. Washington, DC: National Association of Student Personnel Administrators.

Mottarella, K., Fritzsche, B., \& Cerabino, K. (2004). What do students want in advising? A policy capturing study. NACADA Journal, $24(1 \& 2), 48-61$.

Myers, I., \& McCaulley, M. (1985). Manual: A guide to the development and use of the Myers-Briggs Type Indicator. Palo Alto, CA: Consulting Psychologists Press. 
Nadler, L., \& Nadler, M. (1993). The influence of student sex and instructor sex on academic advising communication. Journal on Excellence in College Teaching, 4, 119-130.

Neuman, W. (2006). Social research methods. Boston: Pearson Education, Inc.

Noel, L. (1978). First steps in starting a campus retention program. In L. Noel (Ed.), Reducing the dropout rate Volume 3 of New Directions for Student Services (pp. 87-98). San Francisco: Jossey-Bass.

O’Banion, T. (1994). An academic advising model. NACADA Journal, 14(2), 5-9.

Orne, M. (1962). On the social psychology of the psychological experiment: With particular reference to demand characteristics and their implications. American Psychologist, 17, 776-783. Available online: http://www.psych.upenn.edu/history/orne/orne1962amerpsychol776783.html

Pan, W., Guo, S., Alikonis, C., \& Bai, H. (2008). Do intervention programs assist students to succeed in college: A multilevel longitudinal study. College Student Journal, 42(1), 90-98.

Pardee, C. (1994). We profess developmental advising, but do we practice it? NACADA Journal, 14(2), 59-61.

Perry, W., Jr. (1968). Forms of intellectual and ethical development in the college years: A scheme. Austin, TX: Holt, Rinehart \& Winston.

Piaget, J. (2008). Intellectual evolution from adolescence to adulthood. Human Development, 15, 40-47.

Porter, S., Whitcomb, M., \& Weitzer, W. (2004). Multiple surveys of students and survey fatigue. New Directions for Institutional Research, 121, 63-73. 
Raskin, M. (1979). Critical issue: Faculty advising. Peabody Journal of Education, 56(2), 99-108.

Rest, J. (1979). Development in judging moral issues. Minneapolis: University of Minnesota Press.

Saving, K., \& Keim, M. (1998, December). Student and advisor perceptions of academic advising in two Midwestern colleges of business. College Student Journal, 32, 511-521.

Severy, L., Lee, N., \& Polson, C. (1996). A factor and cluster analysis of the perceived institutional context of academic advising. NACADA Journal, 16(2), 25-33.

Shields, P., \& Gillard, S. (2002). An academic advising profile for marketing educators. Marketing Education Review, 12(2), 37-46.

Smith, C., \& Allen, J. (2006). Essential functions of academic advising: What students want and get. NACADA Journal, 26(1), 56-66.

Somers, P., Woodhouse, S., \& Cofer, J. (2004). Pushing the boulder uphill: The persistence of first-generation college students. The NASPA Journal, 41, 418-435.

Spady, W. (1971). Dropouts from higher education: Toward an empirical model. Interchange, 2(3), 38-62.

Stickle, F. (1982). Faculty and student perception of faculty advising effectiveness. Journal of College Student Personnel, 23, 262-265.

Swanson, D. (2006). Academic advising of undergraduates in communication: Structural models and service challenges identified by faculty. Ohio Communication Journal, 44, 95-108. 
Thomas, R., \& Chickering, A. (1984). Education and identity revisited. Journal of College Student Personnel, 25, 392-399.

Tinto, V. (1993). Leaving college: Rethinking the causes and cures of student attrition ( $2^{\text {nd }}$ ed.). Chicago: The University of Chicago Press.

Tinto, V. (2002). Taking student retention seriously: Rethinking the first year of college. Speech presented at the annual meeting of the American Association of Collegiate Registrars and Admission Officers, April 15, 2002, Minneapolis, MN. Retrieved from http://advisortrainingmanual.pbworks.com/f/ Tinto_TakingRetentionSeriously.pdf

Tinto, V. (2004). Student retention and graduation: Facing the truth, living with the consequences (Occasional Paper 1). Retrieved from The Pell Institute website: http://www.pellinstitute.org/downloads/publicationsStudent_Retention_and_Graduation_July_2004.pdf.

Torres, V. (2009). The developmental dimensions of recognizing racism. Journal of College Student Development, 50, 504-520.

Trombley, T. (1984). An analysis of the complexity of academic advising. Journal of College Student Personnel, 25, 234-240.

Tuttle, K. (2000). Academic advising. New Directions for Higher Education, 111 (fall), 15-24.

Vaquera, G., \& Maestas, R. (2009). Pre-college factors impacting persistence at a diverse university. Journal of College Student Retention: Research, Theory, \& Practice, 10, 425-445. 
Vowell, F., \& Karst, R. (1987). Student satisfaction with faculty advisors in an intrusive advising program. NACADA Journal, 7(2), 31-33.

Waters, R. (2002). Faculty socialization into the advising role: An examination of information and information sources that shape role learning. NACADA Journal, $22(1), 15-25$.

Weir, S., Dickman, M., \& Fuqua, D. (2005). Preferences for academic advising styles. NACADA Journal, 25(1), 74-80.

Wells, R. (2008). Social and cultural capital, race and ethnicity, and college student retention. Journal of College Student Retention, 10(2), 103-128.

Wester, S., \& Vogel, D. (2002). Working with the masculine mystique: Male gender role conflict, counseling self-efficacy, and the training of male psychologists. Professional Psychology: Research and Practice, 4, 370-376.

Wine, J., Heuer, R., Wheeless, S., Francis, T., Franklin, J., \& Dudley, K. (2002) Beginning postsecondary students longitudinal study: 1996-2001 (BPS:96/01) methodology report (NCES 2002-171). Washington, DC: US Department of Education, Office of Educational Research and Improvement.

Winston, R., \& Sandor, J. (1984a). Developmental academic advising: What do students want? NACADA Journal, 4(1), 5-13.

Winston, R., \& Sandor, J. (1984b). The Academic Advising Inventory. Athens, GA: Student Development Associates.

Winston, R., \& Sandor, J. (2002). Evaluating academic advising: Manual for the Academic Advising Inventory. Athens, GA: Student Development Associates. 


\section{APPENDIX A \\ Permission to use the Academic Advising Inventory}

"We are providing the Academic Advising Inventory (AAI) to the academic advising profession under the auspices of the National Academic Advising Association and its Web Site as a means of promoting good practices through thorough, theory-based evaluation. The AAI is provided for the non-commercial use of advising practitioners at no costs by permission of Student Development Associates, Inc. (PMB 500, 2351College Station Road, Athens, GA 30605)-- the copyright holder. No specific permission is required for institutional uses or for research studies. The AAI also may be used in dissertation and thesis research and included as an appendix with the document without written permission from Student Development Associates, Inc.

Permission to Adapt

Users have permission to use AAI Parts I and II in their entirety, that is, either or both of these parts may be used in their entirety, but individual items may not be removed from these two parts for use in other instruments. Users, however, have permission to use individual items from Parts III and IV. Items in Parts III and IV may be altered or eliminated to fit local conditions."

Winston \& Sandor, 2002, p. 2 


\section{APPENDIX B}

Student Preference for Advising Style

\begin{tabular}{|c|c|c|c|c|}
\hline Score & Frequency & Percent & $\begin{array}{l}\text { Valid } \\
\text { Percent }\end{array}$ & $\begin{array}{c}\text { Cumulative } \\
\text { Percent }\end{array}$ \\
\hline 32.00 & 1 & .3 & .4 & .4 \\
\hline 35.00 & 1 & .3 & .4 & .7 \\
\hline 37.00 & 1 & .3 & .4 & 1.1 \\
\hline 38.00 & 1 & .3 & .4 & 1.4 \\
\hline 40.00 & 2 & .7 & .7 & 2.1 \\
\hline 41.00 & 1 & .3 & .4 & 2.5 \\
\hline 42.00 & 1 & .3 & .4 & 2.8 \\
\hline 44.00 & 1 & .3 & .4 & 3.2 \\
\hline 45.00 & 1 & .3 & .4 & 3.5 \\
\hline 46.00 & 1 & .3 & .4 & 3.9 \\
\hline 47.00 & 2 & .7 & .7 & 4.6 \\
\hline 48.00 & 4 & 1.3 & 1.4 & 6.0 \\
\hline 49.00 & 1 & .3 & .4 & 6.3 \\
\hline 51.00 & 2 & .7 & .7 & 7.0 \\
\hline 52.00 & 4 & 1.3 & 1.4 & 8.5 \\
\hline 53.00 & 3 & 1.0 & 1.1 & 9.5 \\
\hline 54.00 & 6 & 2.0 & 2.1 & 11.6 \\
\hline 55.00 & 5 & 1.7 & 1.8 & 13.4 \\
\hline 56.00 & 2 & .7 & .7 & 14.1 \\
\hline 57.00 & 1 & .3 & .4 & 14.4 \\
\hline 58.00 & 6 & 2.0 & 2.1 & 16.5 \\
\hline 59.00 & 5 & 1.7 & 1.8 & 18.3 \\
\hline 60.00 & 3 & 1.0 & 1.1 & 19.4 \\
\hline 61.00 & 6 & 2.0 & 2.1 & 21.5 \\
\hline 62.00 & 7 & 2.3 & 2.5 & 23.9 \\
\hline 63.00 & 3 & 1.0 & 1.1 & 25.0 \\
\hline 64.00 & 4 & 1.3 & 1.4 & 26.4 \\
\hline
\end{tabular}




$\begin{array}{lrrrr}66.00 & 6 & 2.0 & 2.1 & 28.5 \\ 67.00 & 5 & 1.7 & 1.8 & 30.3 \\ 68.00 & 2 & .7 & .7 & 31.0 \\ 69.00 & 1 & .3 & .4 & 31.3 \\ 70.00 & 6 & 2.0 & 2.1 & 33.5 \\ 71.00 & 3 & 1.0 & 1.1 & 34.5 \\ 72.00 & 5 & 1.7 & 1.8 & 36.3 \\ 74.00 & 3 & 1.0 & 1.1 & 37.3 \\ 75.00 & 3 & 1.0 & 1.1 & 38.4 \\ 76.00 & 3 & 1.0 & 1.1 & 39.4 \\ 77.00 & 9 & 3.0 & 3.2 & 42.6 \\ 78.00 & 7 & 2.3 & 2.5 & 45.1 \\ 79.00 & 3 & 1.0 & 1.1 & 46.1 \\ 80.00 & 2 & .7 & .7 & 46.8 \\ 81.00 & 4 & 1.3 & 1.4 & 48.2 \\ 82.00 & 6 & 2.0 & 2.1 & 50.4 \\ 83.00 & 3 & 1.0 & 1.1 & 51.4 \\ 84.00 & 7 & 2.3 & 2.5 & 53.9 \\ 85.00 & 1 & .3 & .4 & 54.2 \\ 86.00 & 4 & 1.3 & 1.4 & 55.6 \\ 87.00 & 2 & .7 & .7 & 56.3 \\ 88.00 & 2 & .7 & .7 & 57.0 \\ 89.00 & 4 & 1.3 & 1.4 & 58.5 \\ 90.00 & 6 & 2.0 & 2.1 & 60.6 \\ 91.00 & 5 & 1.7 & 1.8 & 62.3 \\ 92.00 & 7 & 2.3 & 2.5 & 64.8 \\ 93.00 & 3 & 1.0 & 1.1 & 65.8 \\ 94.00 & 3 & 1.0 & 1.1 & 66.9 \\ 95.00 & 9 & 3.0 & 3.2 & 70.1 \\ 96.00 & 2 & .7 & .7 & 70.8 \\ 97.00 & 3 & 1.0 & 1.1 & 71.8\end{array}$




$\begin{array}{lrrrr}98.00 & 8 & 2.7 & 2.8 & 74.6 \\ 99.00 & 8 & 2.7 & 2.8 & 77.5 \\ 100.00 & 3 & 1.0 & 1.1 & 78.5 \\ 101.00 & 2 & .7 & .7 & 79.2 \\ 102.00 & 7 & 2.3 & 2.5 & 81.7 \\ 103.00 & 7 & 2.3 & 2.5 & 84.2 \\ 104.00 & 6 & 2.0 & 2.1 & 86.3 \\ 105.00 & 8 & 2.7 & 2.8 & 89.1 \\ 106.00 & 3 & 1.0 & 1.1 & 90.1 \\ 107.00 & 4 & 1.3 & 1.4 & 91.5 \\ 108.00 & 5 & 1.7 & 1.8 & 93.3 \\ 109.00 & 3 & 1.0 & 1.1 & 94.4 \\ 111.00 & 1 & .3 & .4 & 94.7 \\ 112.00 & 15 & 5.0 & 5.3 & 100.0 \\ \text { Total } & 284 & 94.7 & 100.0 & \\ \text { Missing } & 16 & 5.3 & & \\ & 300 & 100.0 & & \end{array}$




\section{APPENDIX C}

Advising Style Provided by Advisors

\begin{tabular}{|c|c|c|c|c|c|}
\hline & & Frequency & Percent & $\begin{array}{l}\text { Valid } \\
\text { Percent }\end{array}$ & $\begin{array}{c}\text { Cumulative } \\
\text { Percent }\end{array}$ \\
\hline \multirow[t]{32}{*}{ Valid } & 57.00 & 1 & 2.4 & 2.4 & 2.4 \\
\hline & 58.00 & 1 & 2.4 & 2.4 & 4.9 \\
\hline & 62.00 & 1 & 2.4 & 2.4 & 7.3 \\
\hline & 66.00 & 1 & 2.4 & 2.4 & 9.8 \\
\hline & 68.00 & 1 & 2.4 & 2.4 & 12.2 \\
\hline & 70.00 & 1 & 2.4 & 2.4 & 14.6 \\
\hline & 71.00 & 2 & 4.8 & 4.9 & 19.5 \\
\hline & 72.00 & 1 & 2.4 & 2.4 & 22.0 \\
\hline & 74.00 & 1 & 2.4 & 2.4 & 24.4 \\
\hline & 75.00 & 1 & 2.4 & 2.4 & 26.8 \\
\hline & 77.00 & 2 & 4.8 & 4.9 & 31.7 \\
\hline & 78.00 & 1 & 2.4 & 2.4 & 34.1 \\
\hline & 81.00 & 2 & 4.8 & 4.9 & 39.0 \\
\hline & 83.00 & 1 & 2.4 & 2.4 & 41.5 \\
\hline & 84.00 & 2 & 4.8 & 4.9 & 46.3 \\
\hline & 85.00 & 1 & 2.4 & 2.4 & 48.8 \\
\hline & 86.00 & 4 & 9.5 & 9.8 & 58.5 \\
\hline & 87.00 & 1 & 2.4 & 2.4 & 61.0 \\
\hline & 88.00 & 1 & 2.4 & 2.4 & 63.4 \\
\hline & 90.00 & 1 & 2.4 & 2.4 & 65.9 \\
\hline & 92.00 & 2 & 4.8 & 4.9 & 70.7 \\
\hline & 93.00 & 2 & 4.8 & 4.9 & 75.6 \\
\hline & 95.00 & 1 & 2.4 & 2.4 & 78.0 \\
\hline & 96.00 & 1 & 2.4 & 2.4 & 80.5 \\
\hline & 98.00 & 1 & 2.4 & 2.4 & 82.9 \\
\hline & 99.00 & 1 & 2.4 & 2.4 & 85.4 \\
\hline & 100.00 & 2 & 4.8 & 4.9 & 90.2 \\
\hline & 101.00 & 1 & 2.4 & 2.4 & 92.7 \\
\hline & 105.00 & 1 & 2.4 & 2.4 & 95.1 \\
\hline & 106.00 & 1 & 2.4 & 2.4 & 97.6 \\
\hline & 109.00 & 1 & 2.4 & 2.4 & 100.0 \\
\hline & Total & 41 & 97.6 & 100.0 & \\
\hline Missing & System & 1 & 2.4 & & \\
\hline Total & & 42 & 100.0 & & \\
\hline
\end{tabular}




\section{APPENDIX D}

Advising Style Preferred by Advisors

\begin{tabular}{|c|c|c|c|c|c|}
\hline & & Frequency & Percent & $\begin{array}{l}\text { Valid } \\
\text { Percent }\end{array}$ & $\begin{array}{c}\text { Cumulative } \\
\text { Percent }\end{array}$ \\
\hline \multirow[t]{27}{*}{ Valid } & 60.00 & 2 & 4.8 & 4.9 & 4.9 \\
\hline & 66.00 & 2 & 4.8 & 4.9 & 9.8 \\
\hline & 70.00 & 1 & 2.4 & 2.4 & 12.2 \\
\hline & 71.00 & 1 & 2.4 & 2.4 & 14.6 \\
\hline & 72.00 & 1 & 2.4 & 2.4 & 17.1 \\
\hline & 74.00 & 1 & 2.4 & 2.4 & 19.5 \\
\hline & 78.00 & 1 & 2.4 & 2.4 & 22.0 \\
\hline & 80.00 & 2 & 4.8 & 4.9 & 26.8 \\
\hline & 82.00 & 1 & 2.4 & 2.4 & 29.3 \\
\hline & 83.00 & 1 & 2.4 & 2.4 & 31.7 \\
\hline & 84.00 & 1 & 2.4 & 2.4 & 34.1 \\
\hline & 90.00 & 1 & 2.4 & 2.4 & 36.6 \\
\hline & 96.00 & 3 & 7.1 & 7.3 & 43.9 \\
\hline & 97.00 & 2 & 4.8 & 4.9 & 48.8 \\
\hline & 98.00 & 1 & 2.4 & 2.4 & 51.2 \\
\hline & 100.00 & 1 & 2.4 & 2.4 & 53.7 \\
\hline & 101.00 & 4 & 9.5 & 9.8 & 63.4 \\
\hline & 102.00 & 1 & 2.4 & 2.4 & 65.9 \\
\hline & 103.00 & 1 & 2.4 & 2.4 & 68.3 \\
\hline & 105.00 & 1 & 2.4 & 2.4 & 70.7 \\
\hline & 106.00 & 3 & 7.1 & 7.3 & 78.0 \\
\hline & 107.00 & 2 & 4.8 & 4.9 & 82.9 \\
\hline & 108.00 & 1 & 2.4 & 2.4 & 85.4 \\
\hline & 110.00 & 1 & 2.4 & 2.4 & 87.8 \\
\hline & 111.00 & 1 & 2.4 & 2.4 & 90.2 \\
\hline & 112.00 & 4 & 9.5 & 9.8 & 100.0 \\
\hline & Total & 41 & 97.6 & 100.0 & \\
\hline Missing & System & 1 & 2.4 & & \\
\hline Total & & 42 & 100.0 & & \\
\hline
\end{tabular}




\section{APPENDIX E}

Difference in Advising Style Provided

and Advising Style Preferred by Advisors

\begin{tabular}{|c|c|c|c|c|c|}
\hline & & Frequency & Percent & $\begin{array}{l}\text { Valid } \\
\text { Percent }\end{array}$ & $\begin{array}{c}\text { Cumulative } \\
\text { Percent }\end{array}$ \\
\hline \multirow[t]{27}{*}{ Valid } & -10.00 & 1 & 2.4 & 2.5 & 2.5 \\
\hline & -6.00 & 1 & 2.4 & 2.5 & 5.0 \\
\hline & -3.00 & 2 & 4.8 & 5.0 & 10.0 \\
\hline & -2.00 & 1 & 2.4 & 2.5 & 12.5 \\
\hline & -1.00 & 1 & 2.4 & 2.5 & 15.0 \\
\hline & .00 & 3 & 7.1 & 7.5 & 22.5 \\
\hline & 1.00 & 1 & 2.4 & 2.5 & 25.0 \\
\hline & 2.00 & 2 & 4.8 & 5.0 & 30.0 \\
\hline & 3.00 & 3 & 7.1 & 7.5 & 37.5 \\
\hline & 4.00 & 1 & 2.4 & 2.5 & 40.0 \\
\hline & 5.00 & 2 & 4.8 & 5.0 & 45.0 \\
\hline & 6.00 & 3 & 7.1 & 7.5 & 52.5 \\
\hline & 8.00 & 2 & 4.8 & 5.0 & 57.5 \\
\hline & 9.00 & 1 & 2.4 & 2.5 & 60.0 \\
\hline & 10.00 & 1 & 2.4 & 2.5 & 62.5 \\
\hline & 12.00 & 1 & 2.4 & 2.5 & 65.0 \\
\hline & 13.00 & 1 & 2.4 & 2.5 & 67.5 \\
\hline & 14.00 & 1 & 2.4 & 2.5 & 70.0 \\
\hline & 15.00 & 3 & 7.1 & 7.5 & 77.5 \\
\hline & 18.00 & 2 & 4.8 & 5.0 & 82.5 \\
\hline & 19.00 & 2 & 4.8 & 5.0 & 87.5 \\
\hline & 20.00 & 1 & 2.4 & 2.5 & 90.0 \\
\hline & 26.00 & 1 & 2.4 & 2.5 & 92.5 \\
\hline & 27.00 & 1 & 2.4 & 2.5 & 95.0 \\
\hline & 29.00 & 1 & 2.4 & 2.5 & 97.5 \\
\hline & 30.00 & 1 & 2.4 & 2.5 & 100.0 \\
\hline & Total & 40 & 95.2 & 100.0 & \\
\hline \multirow[t]{2}{*}{ Missing } & System & 2 & 4.8 & & \\
\hline & Total & 42 & 100.0 & & \\
\hline
\end{tabular}




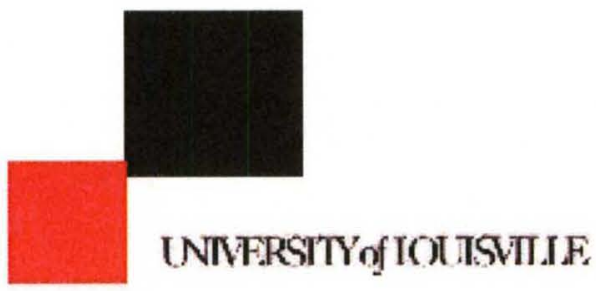

IMSTITUTIONAL REVIEW BOARDS

University of Loulsulle

Medcenter One, Sulte 200

501 E. Broacway

Loulsvile, Kentucky 40202-1796

Omce: $\quad 502-852-5188$

Fax: 502-852-2164

To: $\quad$ Evans, Charles

From: $\quad$ The University of Louisville Institutional Review Board (IRB)

Date: $\quad$ Friday, February 17, 2012

Subject: Approval Letter

Tracking \#: 12.0069

Title:

ADVISING STYLE PERCEPTIONS AND PREFERENCES OF STUDENTS AND ADVISORS

Approval $\quad 2 / 16 / 2012$ 12:00:00 AM

Date:

Expiration 2/15/2013 12:00:00 AM

Date:

This study was reviewed on $02 / 16 / 2012$ by the chair/vice chair of the Institutional Review Board and approved through the Expedited Review Procedure, according to 45 CFR 46.110(b), since this study falls under Expedited Category (7) Research on individual or group characteristics or behavior (including, but not limited to, research on perception, cognition, motivation, identity, language, communication, cultural beliefs or practices, and social behavior) or research employing survey, interview, oral history, focus group, program evaluation, human factors evaluation, or quality assurance methodologies.

This study was also approved through 45 CFR 46.117 (c), which means that an IRB may waive the requirement for the investigator to obtain a signed informed consent form for some or all subjects if it finds either.

- That the only record linking the subject and the research would be the consent document and the principal risk would be potential harm resulting from a breach of confidentiality. Each subject will be asked whether the subject wants documentation linking the subject with the research, and the subject's wishes will govern; or

- That the research presents no more than minimal risk of harm to subjects and involves no procedures for which written consent is normally required outside of the research context.

The following items have been approved:

- survey questions advisor 
APPENDIX F (continued)

- survey questions student

- advisor email

- studiont email

- Please Note: per discussion with chair, all data needs to be maintained securely.

This study now has final IRB approval from 02/16/2012 through 02/15/2013. You should complete and relurn the Progress Reporticontinuation Request Form EIGHT weeks prior to this date in order to ensure that no lapse in approval occurs. The committee will be advised of this action at their next full board meeting.

\section{Site Approval}

If this stucly will take place at an affiliated research institution, such as Jewish Hospitalst Marys Hospital, Norton Healthcare, or University of Louisville Hospital, permission to usc the site of the affiliated institution may be necessary before the research may begin. If this study will take place oulside of the University of Louisvile Campuses, permission from Ine organization should be obtained before the research may begin. Failure to obtain this permission may result in a dolay in the start of your research.

Privacy \& Encryption Statement

The University of Louisville's Privacy and Encryption Policy requires such information as identifiable medical and health records: credit card, bank account and other personal financial information; social security numbers; proprietary research data; dates of birth (when combined with name, address andior phone numbers) to be enorypted. For additional information: http:i/security.louisville.eduiPolStdsiISOIPSO18.htm.

1099 information (II Applicable)

As a reminder, in compliance with University policies and internal Revenue Service code, al payments (including checks, gift cards, and gift certificates) to research subjects must be reported to the University Controller's Office. Petty Cash payments must also be monitored by the issuing department and reported to the Controller's Office. Before issuing compensation, each research subject must complete a $W-9$ form.

For additional information, please contact the Controller's Office at $852-8237$ or contro \|@louisvilie.edu.

Best wishes for a successful study. If you have any questions please contact the $\mathrm{HSPPO}$ at (502) $852-5188$ or hsppofc(allauisville.edu.

Thank you.

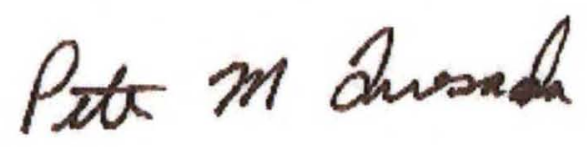


APPENDIX F (continued)

Board Designee: Quesada, Peler

Once you begin your human subject research the following regulations apply:

1. Unanticipated problems or serious adverse events encounterod in this research study must be reported to the IRB within five (5) work days.

2. Any modifications to the study protocol or informed consent form must be reviewed and approved by the IRB prior to implementation.

3. You may not use a modifed informed consent form unit it has been approved and validated by the IRB.

4. Please noto that the IRB operales in accordance with laws and regulations of the United States and guidance provided by the Office of Human Research Protection (OHRP), the Food and Drug Administration (FDA), the Office of Civil Rights (OCR) and other Federal and State Agencies when applicable.

5. You should complete and SUBMIT the Continuation Request Form cight veeks prior to this date in order to ensure that no lapse in approval occurs.

Letter Sent By: Block, Sherry, 2i17/2012 3:22 PN 


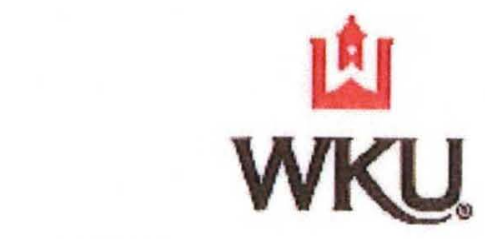

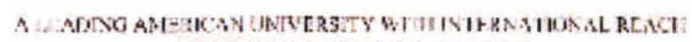

OFFICE OH COUNP IA VTE

DATE:

TO:

FROR:

PROJECT TITLE: REFERENCE H. SUBSIISSION TYPE

ACTION:

APPROVAL DNIE: LXPIRATION DATE REVIEWT TYPE:
Fehruary 22. 2012

Gladys Pat Jordan, HA, MBA.

Wostern Kentu csy Universily (VUKI) IRB

[290047-2] Slutent and Adv sor Preferences "ox Acadomic. Advising Siyle IRB12-18\%

Amendment'Mledif cellon

$$
\text { NPPROVED }
$$

February 2?, 2012

Febrary 15,2013

Expsdited Reyiaw

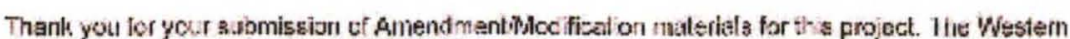
Ken:ucky Uriversity (WKU) IRB has APPROVED your submissicn. This appowal is based on an appropriate risk/henefit rat s snd a project design wherein tha r's 's have bean rinimized. All rese srch must be conducted in eccurdance with this approved subm ssion.

This submission has recelved Lxpedted Rev exv kasad on the applicatl@ federal regulleticn.

Please remertber that iformed censent is a process bayining vith a descriplicn of the profect ard

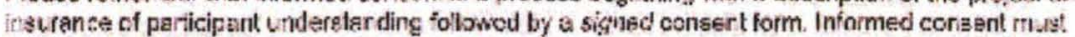
soni nue thro shout the project vis a d alngue between the researcher and research pantisipan:. Fectaral regu atinns require eact: participant receive a copy of the signed sonsert slocument.

Plcase note that any rev sian to previously approwed materials must be approwod by this office prior to initiaticn. Plesse use the appropriate resis on form s for this pruced ure.

MI UNANTICIPATCD PROBLENS inwolvirg risks to subjects or otners and SERIOUS and UNEXPECTED sdverse cvert: must oe reported prompty to thi julfce. Plesse usa the appropriate rearting forms for this prosecune All TDA and sponsor rcporting reotiremants should alsu be followed.

AI NON-COMPLIANCL isques or CCMPLAIN IS regarding thia project must be reported prornply' to this ofice.

This project has been detarmired io be a Minir al Risk prejoct. Basec on the raks, this project requires continuing review by th is committee on an gnnua bas 3 . Plesse use the approarlate forms for this prosedure. Your dow mentation for continu rg reviews must be roveived with aufisent timo for review and contirtued aproval bafora the expication cate of Fol:uary' 16, 2013.

Plasse ncto that all research recoros must be rela ned for a minimun si threc yoa's after the complation of the project. 
APPENDIX G (continued)

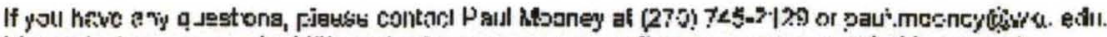

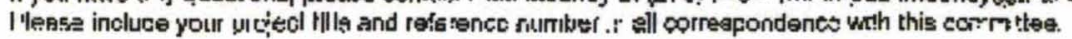

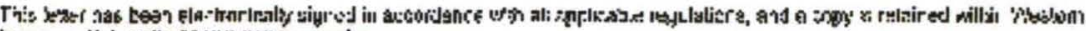

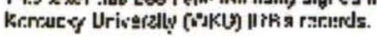


APPENDIX G (continued)

ADVISOR FMAII.
Dear Advisor,

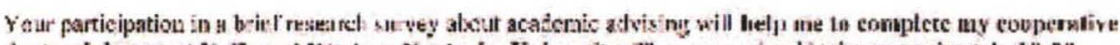

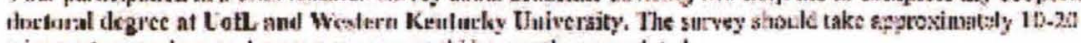
mirutes to complecs, and your respans would he aceatly appre vialed

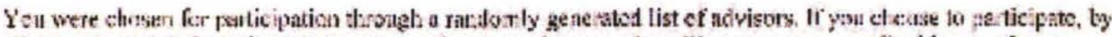

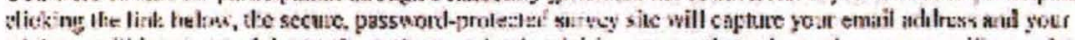

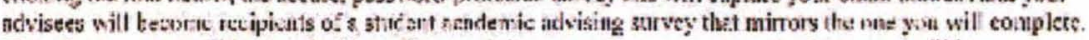

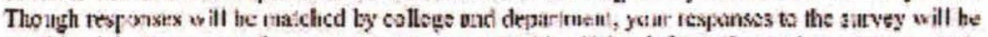

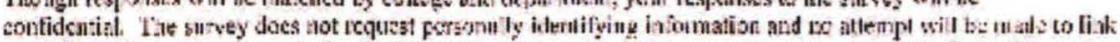

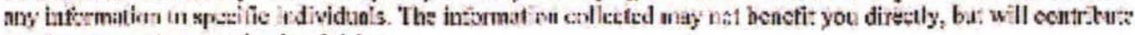
bo other resench on acedenic advising

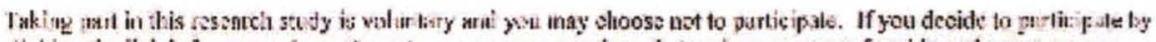

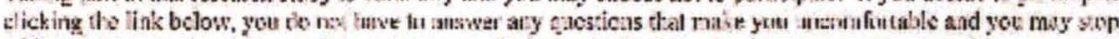

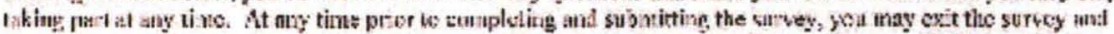

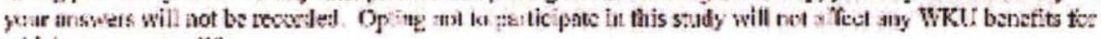
which yea nasy umalify

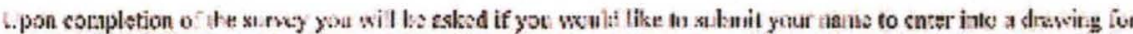

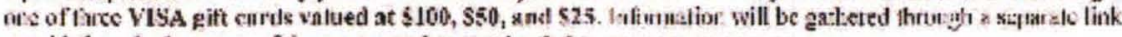

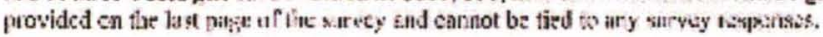

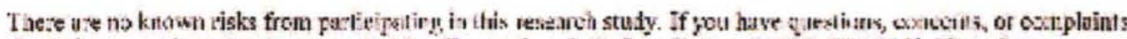

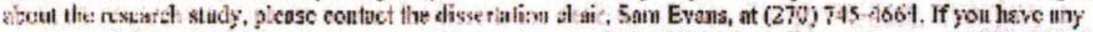

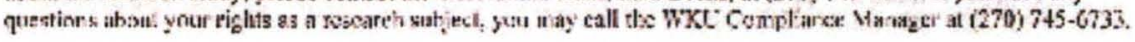

\section{Continuing to the retmork stirvey inglies consent.}

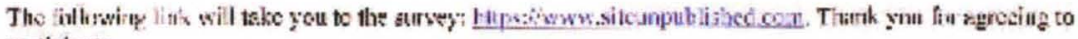
participuse.

Sincerely,

Pat Jo:dza, Sadent Reteareiut

and

Scus Evans, Dissertation Chair

TIIIS PRCNIXI HAS BEER RCVITWTII) ANI) AIPROYED BY

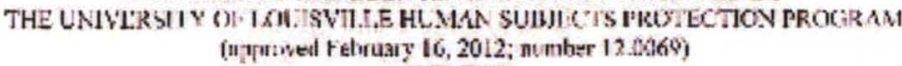

AND THF

WESTERYKTVILCKY UANEKSITY INSTITUTIONAL RIVIFW ROARD

(aoprove: I leătuaเv 22. 20.2; number 12-160)

Pai Mecony, WK1J H..nan Protceticus Aininisiralur

TII.T:PIONE: (270) 745-6733

WKU IRB

Approval - 2/22/2012

End Date - 2/15/2013

Expedited

Original - 2/22/2012 


\title{
APPENDIX G (continued)
}

\section{STUDENT EMAII.}

Theur Student,

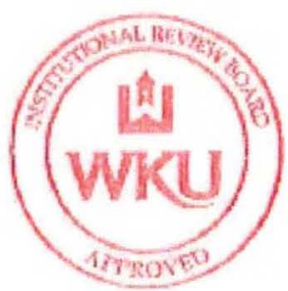

Your participation in a brief research survey about academic advising will help me to sumplete my cooperative doctural degree at Loff. and Wusteru Kentuchy tiniversity. The survey shsuld take appmximately $10-20$ ininutes to compleit, and your response wowld be gesatly appreciales. The information collecled may not heneit you directly, but will cintribute to other roscarch an scudenic advising.

thugh respottses will be matuhed by college and depurtment. your rcsponses to the survey will bo anonymous and coufidsntisl. The survey doos not recuest personally identifying information and no attempt will be tuade to link any inliornation to specific individuals.

Taking part in this fescarch study is voluntaty and you ma choose not to perticipote. If you cecidc to participute by clicking the link below, you do not have to answer any questions that make you uneor forlathle and you may stop taking port at any time. At any time prisor to comple.ing and submitting the survey, you may cxit the servey and your arswers will not be sccorded. Opting not to participale in this atudy will nut aflect any WKU henefix for which you may cualify. If you are under the age of 18 , plense do not participate in the stuly.

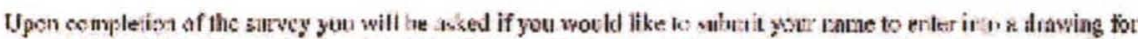

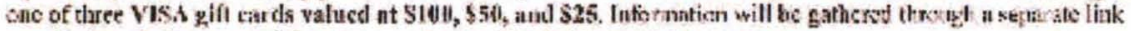

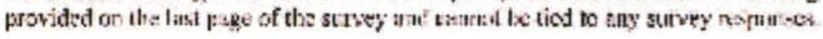

There nro ro kmown riks from participating in 1 ix reicerch st.ıdy. If you hwe questions, concerns, er eompleints

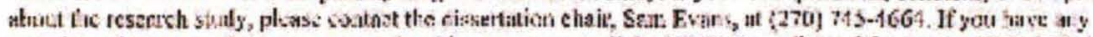

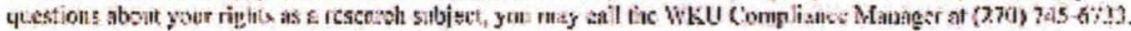

Cinshisenting to the rescure is survy dinyslies cousew.

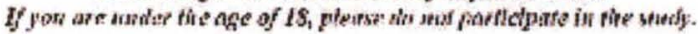

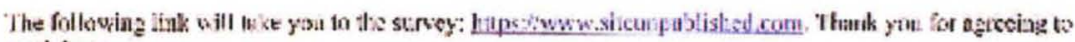
particitric

Sincerely:

Pat Jord all, Siutent Resantcie:

z.nd

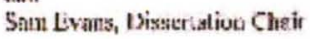

\author{
JHIS PROIIR THNS BHTR KEVIIWTD ANIS APPROVED BY \\ TIII UNTSFRSITY O: LUUISVILLE HUMAV SHIBIS'IS IROTECTION PRTXIKAM

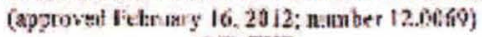 \\ AND THE \\ WISIRKA KENTUCKY IVIVIRSITY INSTILTINAI, REVTFW BOARD \\ (spproved lebertary 22, 2012; number 12-16D) \\ Paul Mooney, WKU ITutant Protections Administrator
}

TEI.TPIIONE: (270) $745-6733$ 


\section{APPENDIX H}

\section{ACADEMIC ADVISING INVENTORY - ADVISOR}

\section{CONFIDENTIALITY INFORMATION}

You are being invited to participate in a research study conducted by a doctoral candidate. University standards require that you consent to take part in the study. The information collected may not benefit you directly, but will contribute to other research on academic advising. You will be given an opportunity to continue with this survey by clicking on the double arrows $(>>)$ at the bottom of this screen. Choosing to continue with the research study implies consent.

Taking part in this research study is voluntary and you may choose not to participate. If you decide to participate by clicking on the double arrows $(>>)$ at the bottom of this screen, you do not have to answer any questions that make you uncomfortable and you may stop taking part at any time. The secure, password-protected survey site will capture your email address and your advisees will become recipients of a student academic advising survey that mirrors the one you will complete. Though responses will be matched by college and department, your responses to the survey will be confidential. At any time prior to completing and submitting the survey, you may exit the survey and your answers will not be recorded. Opting not to participate in this study will not affect any WKU benefits for which you may qualify.

Upon completion of the survey you will be asked if you would like to submit your name to enter into a drawing for one of three VISA gift cards valued at $\$ \mathbf{1 0 0 ,} \mathbf{\$ 5 0}$, and $\mathbf{\$ 2 5}$. Information will be gathered through a separate link provided on the last page of the survey and cannot be tied to any survey responses.

There are no known risks from participating in this research study. If you have questions, concerns, or complaints about the research study, please contact the dissertation chair, Sam Evans, at (270) 745-4664. If you have any questions about your rights as a research subject, you may call the WKU Compliance Manager at (270) 745-2129.

Continuing to the research survey implies consent.

Thank you for taking part in the survey.

THIS PROJECT HAS BEEN REVIEWED AND APPROVED BY

THE UNIVERSITY OF LOUISVILLE HUMAN SUBJECTS PROTECTION PROGRAM

(approved February 16, 2012; number 12.0069)

AND THE

WESTERN KENTUCKY UNIVERSITY INSTITUTIONAL REVIEW BOARD

(approved February 22, 2012; number 12-160)

Paul Mooney, WKU Human Protections Administrator

TELEPHONE: (270) 745-2129

Permissions for the Academic Advising Inventory stipulate that Part I should not be altered for use. As an advisor, please respond to the questions based on the way you approached academic advising with your advisees over the past year. First consider both statements to decide which statement best fits your style and then rate the accuracy of the statement. 


\section{ACADEMIC ADVISING INVENTORY}

Roger B. Winston, Jr. and Janet A. Sandor

\section{PART I}

Part I of this Inventory concerns how you and your advisor approach academic advising. Even if you have had more than one advisor or have been in more than one type of advising situation this year, please respond to the statements in terms of your current situation.

There are 14 pairs of statements in Part I. You must make two decisions about each pair in order to respond: (1) decide which one of the two statements most accurately describes the academic advising you received this year, and then (2) decide how accurate or true that statement is (from very true to slightly true).

Click the box that indicates the correct response.

\section{EXAMPLE}

My advisor plans my schedule

Very

True

[ ]

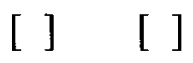

Slightly

True
OR My advisor and I plan my schedule together Slightly

True [ ]
Very

True

EXPLANATION for RESPONSE: In this example, the student has chosen the statement on the right as more descriptive of his or her academic advising this year, and determined that the statement is toward the slightly true end.

1. My advisor is interested in helping me learn how to find out about courses and programs for myself.

Very

True

$\mathrm{O}$

$$
\text { O }
$$

Slightly

True

0

2. My advisor tells me what would be the best schedule for me.

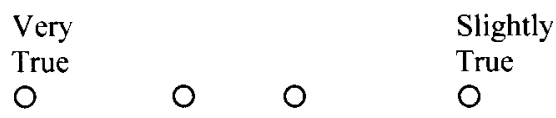

3. My advisor and I talk about vocational opportunities in conjunction with advising.

$\begin{array}{llll}\text { Very } & & & \text { Slightly } \\ \text { True } & & & \text { True } \\ 0 & 0 & 0 & 0\end{array}$

OR My advisor tells me what I need to know about academic courses and programs. Slightly

True

$\mathrm{O}$

My advisor suggests important considerations in planning a schedule and then gives me responsibility for the final decision.

Slightly Very True True $\begin{array}{llll}0 & 0 & 0 & 0\end{array}$

My advisor and I do not talk about vocational opportunities in conjunction with advising.

Slightly

True

Very

0

$\mathrm{O}$ True 
4. My advisor shows an interest in my outside-of-class activities and sometimes suggests activities.

$\begin{array}{llll}\text { Very } & & & \begin{array}{l}\text { Slightly } \\ \text { True }\end{array} \\ \text { True } & & & 0\end{array}$

5. My advisor assists me in identifying realistic academic goals based on what I know about myself, as well as about my test scores and grades.

$\begin{array}{llll}\text { Very } & & & \text { Slightly } \\ \text { True } & & & \text { True } \\ 0 & 0 & 0 & 0\end{array}$

6. My advisor registers me for my classes.

$\begin{array}{llll}\text { Very } & & & \begin{array}{l}\text { Slightly } \\ \text { True } \\ \text { True }\end{array} \\ 0 & 0 & 0 & 0\end{array}$

7. When I'm faced with difficult decisions my advisor tells me my alternatives and which one is the best choice.

$\begin{array}{llll}\text { Very } & & & \text { Slightly } \\ \text { True } & & & \text { True } \\ 0 & 0 & 0 & 0\end{array}$

8. My advisor does not know who to contact about other-than-academic problems.

Very

True

O

$\begin{array}{ll} & \begin{array}{l}\text { Slightly } \\ \text { True }\end{array} \\ 0 & 0\end{array}$

9. My advisor gives me tips on managing my time better $\mathbf{O R}$ or on studying more effectively when I seem to need them.

$\begin{array}{llll}\text { Very } & & & \text { Slightly } \\ \text { True } & & & \text { True } \\ 0 & 0 & 0 & 0\end{array}$

10. My advisor tells me what I must do in order to be advised.

$\begin{array}{llll}\text { Very } & & & \text { Slightly } \\ \text { True } & & & \text { True } \\ 0 & 0 & 0 & 0\end{array}$

11. My advisor suggests what I should major in.

$\begin{array}{llll}\text { Very } & & & \text { Slightly } \\ \text { True } & & & \text { True } \\ 0 & 0 & 0 & 0\end{array}$

12. My advisor uses test scores and grades to let him or her know what courses are most appropriate for me to take.

$\begin{array}{llll}\text { Very } & & & \begin{array}{l}\text { Slightly } \\ \text { True }\end{array} \\ \text { True } & & & 0\end{array}$

13. My advisor talks with me about my other-thanacademic interests and plans.

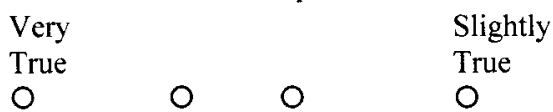

14. My advisor keeps me informed of my academic progress by examining my files and grades only.
OR

My advisor does not know what I do outside of class.

$\begin{array}{llll}\text { Slightly } & & \text { Very } \\ \text { True } & & & \text { True } \\ 0 & 0 & 0 & 0\end{array}$

OR My advisor identifies realistic academic goals for me based on my test scores and grades.

$\begin{array}{llll}\text { Slightly } & & \text { Very } \\ \text { True } & & & \text { True } \\ 0 & 0 & 0 & 0\end{array}$

OR My advisor teaches me how to register myself for classes.
Slightly
True
Very
$\mathrm{O}$
O
True

OR When I'm faced with difficult decisions, my advisor assists me in identifying alternatives and in considering the consequences of choosing each alternative.

$\begin{array}{llll}\text { Slightly } & & & \text { Very } \\ \text { True } & & & \text { True } \\ 0 & 0 & 0 & 0\end{array}$

OR

My advisor knows who to contact about other-thanacademic problems.

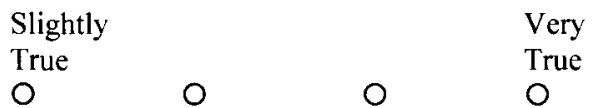

My advisor does not spend time giving me tips on managing my time better or on studying more effectively.

$\begin{array}{llll}\text { Slightly } & & & \text { Very } \\ \text { True } & & & \text { True } \\ 0 & 0 & 0 & 0\end{array}$

OR My advisor and I discuss our expectations of advising and of each other.

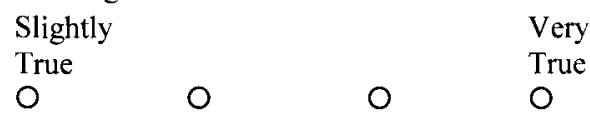

OR My advisor suggests steps I can take to help me decide on a major.
Slightly
True
Very
O

OR My advisor and I use information, such as test scores, grades, interests, and abilities, to determine what courses are most appropriate for me to take.

$\begin{array}{llll}\text { Slightly } & & & \text { Very } \\ \text { True } & & & \text { True } \\ 0 & 0 & 0 & 0\end{array}$

OR My advisor does not talk with me about interests and plans other than academic ones.

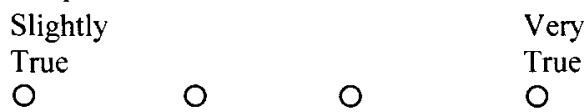

OR My advisor keeps me informed of my academic progress by examining my files and grades and by 


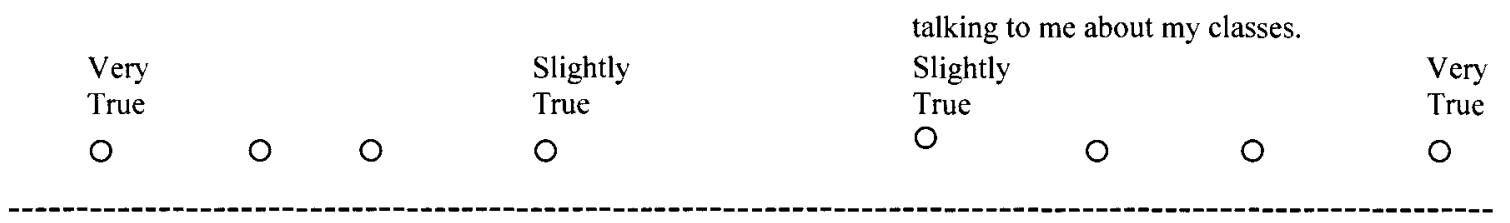

\section{PART II}

15. Considering the academic advising you have provided this year, respond to the following five statements:

$$
\text { A }=\text { Strongly Disagree } \quad \text { B }=\text { Disagree } \quad \text { C }=\text { Agree } \quad \text { D }=\text { Strongly Agree }
$$

I am satisfied in general with the academic advising I have provided.

I provide accurate information about courses, programs, and requirements.

Advising is considered (for faculty advisors) in tenure guidelines in my college.

Advising is valued in my college.

Sufficient time is available for advising sessions.

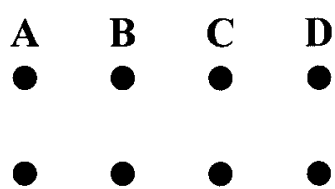

\section{PART III}

Please respond to the following questions by checking the appropriate box(es).

16. What is your gender? Male $\square \quad$ Female

17. What is your age?

21 and Under

22 to 34

35 to 44

45 to 54

55 to 64

65 and Over

Decline

18. Are you a: $\quad$ Faculty Advisor $\square \quad$ Professional Advisor $\square$

19. How long have you served as an advisor at this institution:

$1-5$ years

6-10 years

$11-15$ years

16-20 years 
more than 20 years

20. How long have you served as an advisor overall:
$1-5$ years
$6-10$ years
$11-15$ years
$16-20$ years
more than 20 years

21. Please indicate the college/department/office for which you advise (alpha order by college and department):

COLLEGE OF EDUCATION AND BEHAVIORAL SCIENCES

Exploratory/Undecided

Military Science

Psychology

School of Teacher Education

COLLEGE OF HEALTH AND HUMAN SERVICES

Exploratory/Undecided

Allied Health

Communication Disorders

Family and Consumer Sciences

Kinesiology, Recreation \& Sport

Public Health

School of Nursing

Social Work

GORDON FORD COLLEGE OF BUSINESS

Exploratory/Undecided

Accounting

Computer Information Systems

Economics

Finance

Management

Marketing

OGDEN COLLEGE OF SCIENCE AND ENGINEERING

Exploratory/Undecided

Agriculture

Architectural \& Manufacturing Sciences

Biology

Chemistry

Engineering

Geography and Geology 
Mathematics and Computer Science

Physics and Astronomy

POTTER COLLEGE OF ARTS AND LETTERS

Exploratory/Undecided

Art

Communication

English

Folk Studies/Anthropology

History

Journalism and Broadcasting

Modern Languages

Music

Philosophy/Religion

Political Science

Sociology

Theatre and Dance

UNIVERSITY COLLEGE

Exploratory/Undecided

Computer Information Technology

Extended Campus - Elizabethtown

Extended Campus - Glasgow

Extended Campus - Owensboro

Interdisciplinary Studies

South Campus - Academic Support

South Campus - Liberal Arts and Sciences

South Campus - Professional Studies

Systems Management

Women's Studies

\section{PART IV}

Part IV of this Inventory concerns your ideal academic advising experience. Please respond to the statements in terms of how you would most like to advise students. As in Part I, there are 14 pairs of statements in Part IV.

22. My advisor is interested in helping me $\mathbf{O R}$ learn how to find out about courses and programs for myself.

$\begin{array}{llll}\text { Very } & & & \begin{array}{l}\text { Slightly } \\ \text { True } \\ \text { True }\end{array} \\ 0 & 0 & 0 & 0\end{array}$

23. My advisor tells me what would be the $\mathbf{O R}$ best schedule for me.
My advisor tells me what I need to know about academic courses and programs.

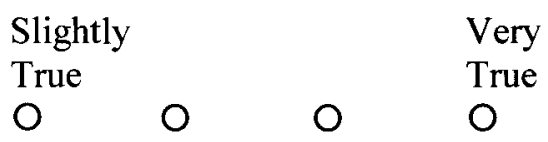

My advisor suggests important considerations in planning a schedule and 
Very

True

$\mathrm{O}$

24. My advisor and I talk about vocational opportunities in conjunction with advising.

$\begin{array}{llll}\text { Very } & & & \begin{array}{l}\text { Slightly } \\ \text { True } \\ \text { True }\end{array} \\ 0 & 0 & 0 & 0\end{array}$

25. My advisor shows an interest in my outside-of-class activities and sometimes suggests activities.

$\begin{array}{llll}\text { Very } & & & \begin{array}{l}\text { Slightly } \\ \text { True }\end{array} \\ \text { True } & & & 0\end{array}$

26. My advisor assists me in identifying realistic academic goals based on what I know about myself, as well as about my test scores and grades.

Very

True

Slightly

O

O

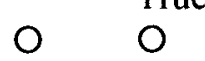

27. My advisor registers me for my classes.

OR

$\begin{array}{llll}\text { Very } & & & \begin{array}{l}\text { Slightly } \\ \text { True } \\ \text { True }\end{array} \\ 0 & 0 & 0 & 0\end{array}$

28. When I'm faced with difficult decisions $\mathbf{O R}$ my advisor tells me my alternatives and which one is the best choice.
Very
Slightly
True
True
O
O
O
$\mathrm{O}$

29. My advisor does not know who to contact about other-than-academic problems.
Very
True
Slightly
O

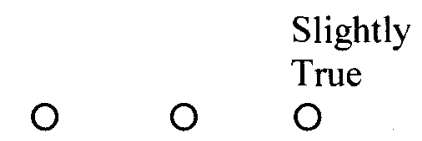

30. My advisor gives me tips on managing $\mathbf{O R}$ my time better or on studying more effectively when I seem to need them.

$\begin{array}{ll}\text { Very } & \text { Slightly } \\ \text { True } & \text { True }\end{array}$

then gives me responsibility for the final decision.
Slightly
Very
True
True
O

O
O
O

OR My advisor and I do not talk about vocational opportunities in conjunction with advising.

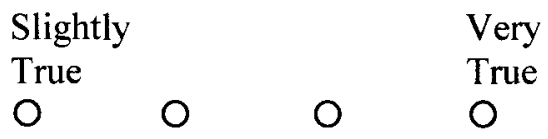

OR My advisor does not know what I do outside of class.

$\begin{array}{llll}\text { Slightly } & & & \text { Very } \\ \text { True } & & & \text { True } \\ 0 & 0 & 0 & 0\end{array}$

OR My advisor identifies realistic academic goals for me based on my test scores and grades.

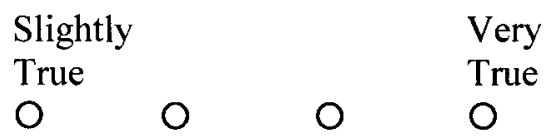

My advisor teaches me how to register myself for classes.

$\begin{array}{llll}\text { Slightly } & & & \text { Very } \\ \text { True } & & & \text { True } \\ 0 & 0 & 0 & 0\end{array}$

When I'm faced with difficult decisions, my advisor assists me in identifying alternatives and in considering the consequences of choosing each alternative.
Slightly
Very
True
True
$\mathrm{O}$

OR My advisor knows who to contact about other-than-academic problems.

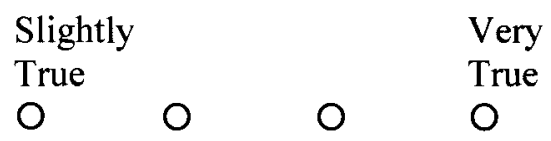

My advisor does not spend time giving me tips on managing my time better or on studying more effectively.

$\begin{array}{ll}\text { Slightly } & \text { Very } \\ \text { True } & \text { True }\end{array}$


31. My advisor tells me what I must do in order to be advised.

$\begin{array}{llll}\text { Very } & & & \begin{array}{l}\text { Slightly } \\ \text { True }\end{array} \\ \text { True } & & & 0 \\ 0 & 0 & 0 & 0\end{array}$

32. My advisor suggests what I should major in.

$\begin{array}{llll}\text { Very } & & & \begin{array}{l}\text { Slightly } \\ \text { True }\end{array} \\ \text { True } & & & \\ 0 & 0 & 0 & 0\end{array}$

33. My advisor uses test scores and grades to let him or her know what courses are most appropriate for me to take.
Very
True
Slightly
O
O
O
True

34. My advisor talks with me about my other-than-academic interests and plans.
Very
True
O
Slightly
True
$\mathrm{O}$

35. My advisor keeps me informed of my academic progress by examining my

files and grades only.

$\begin{array}{llll}\text { Very } & & & \begin{array}{l}\text { Slightly } \\ \text { True }\end{array} \\ \text { True } & & & 0 \\ 0 & 0 & 0 & 0\end{array}$

OR My advisor and I discuss our expectations of advising and of each other.

$\begin{array}{llll}\text { Slightly } & & & \text { Very } \\ \text { True } & & & \text { True } \\ 0 & 0 & 0 & 0\end{array}$

OR My advisor suggests steps I can take to help me decide on a major.

$\begin{array}{llll}\text { Slightly } & & & \text { Very } \\ \text { True } & & & \text { True } \\ 0 & 0 & 0 & 0\end{array}$

OR My advisor and I use information, such as test scores, grades, interests, and abilities, to determine what courses are most appropriate for me to take.

$\begin{array}{llll}\text { Slightly } & & & \text { Very } \\ \text { True } & & & \text { True } \\ 0 & 0 & 0 & 0\end{array}$

OR My advisor does not talk with me about interests and plans other than academic ones.

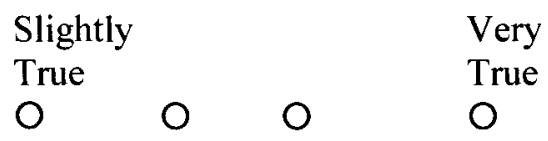

OR My advisor keeps me informed of my academic progress by examining my files and grades and by talking to me about my classes.

Slightly Very

True True

O 000

You have completed the survey.

If you would like to enter your name in a drawing for one of three VISA gift cards valued at $\$ 100, \$ 50$, and $\$ 25$, please click on the URL below. You will be redirected to a form where you will simply provide your name, a current telephone number, and your campus address. Your personal information cannot be tied to your survey responses.

\section{https://wku.qualtrtics.com/entry-form}

Thank you, sincerely, for taking time from your busy schedule to respond to the survey. 


\section{APPENDIX I}

\section{ACADEMIC ADVISING INVENTORY - STUDENT}

\section{CONFIDENTIALITY INFORMATION}

You are being invited to participate in a research study conducted by a doctoral candidate. University standards require that you consent to take part in the study. The information collected may not benefit you directly, but will contribute to other research on academic advising. You will be given an opportunity to continue with this survey by clicking on the double arrows $(\gg)$ at the bottom of this screen. Should you choose to continue to the research study your consent is implied.

Taking part in this research study is voluntary and you may choose not to participate. If you decide to participate by clicking on the double arrows $(>>)$ at the bottom of this screen, you do not have to answer any questions that make you uncomfortable and you may stop taking part at any time. At any time prior to completing and submitting the survey, you may exit the survey and your answers will not be recorded. Opting not to participate in this study will not affect any WKU benefits for which you may qualify.

Upon completion of the survey you will be asked if you would like to submit your name to enter into a drawing for one of three VISA gift cards valued at \$100, \$50, and \$25. Information will be gathered through a separate link provided on the last page of the survey and cannot be tied to any survey responses.

There are no known risks from participating in this research study. If you have questions, concerns, or complaints about the research study, please contact the dissertation chair, Sam Evans, at (270) 745-4664. If you have any questions about your rights as a research subject, you may call the WKU Compliance Manager at (270) 745-2129.

Continuing to the research survey implies consent. Please do not respond to the survey if you are younger than 18 years of age.

Thank you for taking part in the survey.

THIS PROJECT HAS BEEN REVIEWED AND APPROVED BY THE UNIVERSITY OF LOUISVILLE HUMAN SUBJECTS PROTECTION PROGRAM

(approved February 16, 2012; number 12.0069)

AND THE

WESTERN KENTUCKY UNIVERSITY INSTITUTIONAL REVIEW BOARD

(approved February 22, 2012; number 12-0069)

Paul Mooney, WKU Human Protections Administrator

TELEPHONE: (270) 745-2129 


\section{ACADEMIC ADVISING INVENTORY \\ Roger B. Winston, Jr. and Janet A. Sandor}

\section{PART I}

Part I of this Inventory concerns how you and your advisor approach academic advising. Even if you have had more than one advisor or have been in more than one type of advising situation this year, please respond to the statements in terms of your current situation.

There are 14 pairs of statements in Part I. You must make two decisions about each pair in order to respond: (1) decide which one of the two statements most accurately describes the academic advising you received this year, and then (2) decide how accurate or true that statement is (from very true to slightly true).

Click the box that indicates the correct response.

\section{EXAMPLE}

My advisor plans my schedule

Very

True

Slightly

True

[ ]
OR My advisor and I plan my schedule together Slightly

Very

True

[ ]

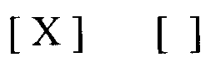

True

EXPLANATION for RESPONSE: In this example, the student has chosen the statement on the right as more descriptive of his or her academic advising this year, and determined that the statement is toward the slightly true end.

1. My advisor is interested in helping me learn how to find out about courses and programs for myself.

Very

True

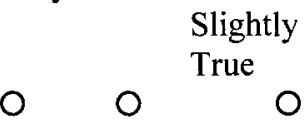

2. My advisor tells me what would be the best schedule for me.

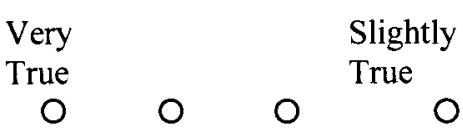

3. My advisor and I talk about vocational opportunities in conjunction with advising.

Very

True

Slightly

True
OR My advisor tells me what I need to know about academic courses and programs.

$\begin{array}{llrr}\text { Slightly } & & & \begin{array}{r}\text { Very } \\ \text { True }\end{array} \\ 0 & 0 & 0 & 0\end{array}$

OR My advisor suggests important considerations in planning a schedule and then gives me responsibility for the final decision.

Slightly Very

True

True

$\begin{array}{llll}0 & 0 & 0 & 0\end{array}$

OR My advisor and I do not talk about vocational opportunities in conjunction with advising.

Slightly

True

Very

True 
4. My advisor shows an interest in my outside-of-class activities and sometimes suggests activities.

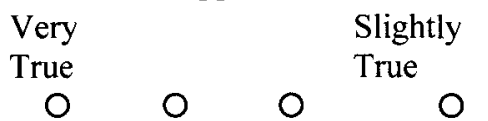

5. My advisor assists me in identifying realistic academic goals based on what I know about myself, as well as about my test scores and grades.

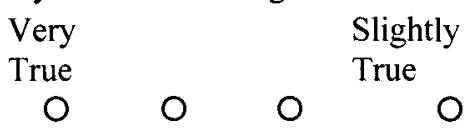

6. My advisor registers me for my classes.

$\begin{array}{cccc}\text { Very } & & & \begin{array}{c}\text { Slightly } \\ \text { True }\end{array} \\ 0 & 0 & 0 & 0\end{array}$

7. When I'm faced with difficult decisions my advisor tells me my alternatives and which one is the best choice.

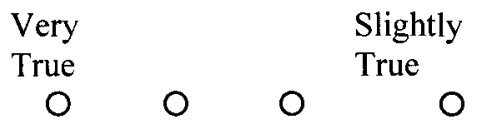

8. My advisor does not know who to contact about other-than-academic problems.

Very

True

Slightly

O

$0 \quad 0 \quad 0$

9. My advisor gives me tips on managing my time better or on studying more effectively when I seem to need them.

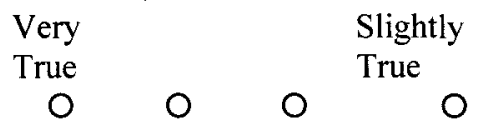

10. My advisor tells me what I must do in order to be advised.
Very
True

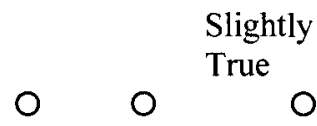

11. My advisor suggests what I should major in.

\begin{tabular}{|c|c|c|}
\hline Very & & \\
\hline True & & \\
\hline 0 & 0 & 0 \\
\hline
\end{tabular}

12. My advisor uses test scores and grades to let him or her know what courses are most appropriate for me to take.
OR My advisor does not know what I do outside of class.

Slightly

True

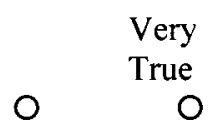

OR My advisor identifies realistic academic goals for me based on my test scores and grades.

Slightly

True

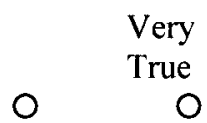

OR My advisor teaches me how to register myself for classes.

Slightly

True

Very

True<smiles>O</smiles>

OR When I'm faced with difficult decisions, my advisor assists me in identifying alternatives and in considering the consequences of choosing each alternative.

$\begin{array}{ccrr}\text { Slightly } & & \text { Very } \\ \text { True } & & & \text { True } \\ 0 & 0 & 0 & 0\end{array}$

OR My advisor knows who to contact about other-than-academic problems.

Slightly

Very

True

True
O
O
O

O

OR My advisor does not spend time giving me tips on managing my time better or on studying more effectively.

$\begin{array}{ccrr}\begin{array}{l}\text { Slightly } \\ \text { True }\end{array} & & \begin{array}{r}\text { Very } \\ \text { True }\end{array} \\ 0 & 0 & 0 & 0\end{array}$

OR My advisor and I discuss our expectations of advising and of each other.
Slightly
True

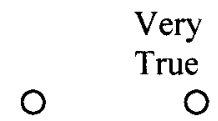

OR My advisor suggests steps I can take to help me decide on a major.

$\begin{array}{ccrr}\text { Slightly } & & & \text { Very } \\ \text { True } & & & \text { True } \\ 0 & 0 & 0 & 0\end{array}$

OR My advisor and I use information, such as test scores, grades, interests, and abilities, to determine what courses are most appropriate for me to take. 


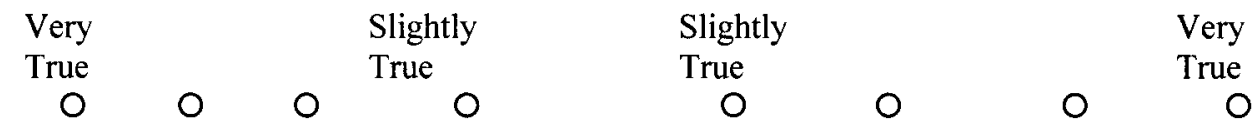

13. My advisor talks with me about my other-than-academic interests and plans.

OR My advisor does not talk with me about interests and plans other than academic ones.

Very Slightly

True True

Slightly Very

True True

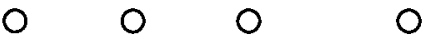

14. My advisor keeps mi informed of my academic progress by examining my files and grades only.

OR My advisor keeps me informed of my academic progress by examining my files and grades and by talking to me about my classes.

Slightly Very

\begin{tabular}{|c|c|c|c|}
\hline Very & Slightly & Slightly & Very \\
\hline True & True & True & True \\
\hline
\end{tabular}

\section{PART II}

15. Considering the academic advising you have participated in at this college this year, respond to the following five statements on the answer sheet using the code below.
$A=$ Strongly Disagree
$\mathbf{B}=$ Disagree
$\mathrm{C}=$ Agree
D = Strongly Agree

I am satisfied in general with the academic advising I have received.

I have received accurate information about courses, programs, and requirements through academic advising.

Sufficient prior notice has been provided about deadlines related to institutional policies and procedures.

Advising has been available when I needed it.

Sufficient time has been available during advising sessions.

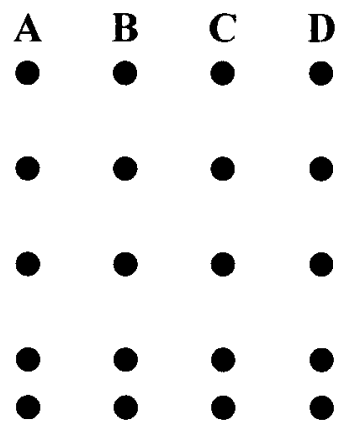

\section{PART III}

Please respond to the following questions by checking the appropriate box(es).

16. What is your gender? Male $\square \quad$ Female

17. What is your cultural/racial background?

Nonresident Alien

Black/African American

American Indian/Native Alaskan

Asian 
Hispanic (of any race)

White

Two or more races

Native Hawaiian/Pacific Islander

Prefer not to answer

18. Are you: Between 18-25 $\square \quad 25$ years of age or older $\square$

19. What is your academic class standing?

$\begin{array}{lllll}\text { Freshman } & \text { Sophomore } \square & \text { Junior } \\ \end{array} \quad$ Senior $\square \quad$ Other $\square$

20. Do you attend:

Part-time (less than 12 credit hours per semester) $\square \quad$ Full-time (12 credit hour or more per semester)

21. Please indicate the level education achieved by your parent(s):

MOTHER

High school diploma or less

Some college

Bachelor degree

Master degree or higher
FATHER

High school diploma or less

Some college

Bachelor degree

Master degree or higher

22. On which campus do you receive advising?
Main
South
Elizabethtown/Ft. Knox
Glasgow
Owensboro

23. Were you advised in your college?

YES

NO

NAD

24. If you were advised in your college, were you advised in your department? YES $\square$ NO $\square$ NA

25. Were you advised by your assigned advisor? $\quad$ YES $\square \quad$ NO

26. If you weren't advised in your college or department, by who were you advised?

Athletic Advisor

Honors Advisor

SSS Advisor 
AARC Advisor

Other

27. Please indicate the range for your GPA.

$3.5-4.0$

$3.0-3.5$

$2.5-3.0$

2.0-2.5

less than 2.0

28. Please indicate your major college and department separately (check all boxes that apply - alpha by college and major):

COLLEGE OF EDUCATION AND BEHAVIORAL SCIENCES

Exploratory/Undecided

Military Science

Psychology

School of Teacher Education

COLLEGE OF HEALTH AND HUMAN SERVICES

Exploratory/Undecided

Allied Health

Communication Disorders

Family and Consumer Sciences

Kinesiology, Recreation \& Sport

Public Health

School of Nursing

Social Work

GORDON FORD COLLEGE OF BUSINESS

Exploratory/Undecided

Accounting

Computer Information Systems

Economics

Finance

Management

Marketing

OGDEN COLLEGE OF SCIENCE AND ENGINEERING

Exploratory/Undecided

Agriculture

Architectural \& Manufacturing Sciences

Biology

Chemistry

Engineering 
Geography and Geology

Mathematics and Computer Science

Physics and Astronomy

POTTER COLLEGE OF ARTS AND LETTERS

Exploratory/Undecided

Art

Communication

English

Folk Studies/Anthropology

History

Journalism and Broadcasting

Modern Languages

Music

Philosophy/ Religion

Political Science

Sociology

Theatre and Dance

UNIVERSITY COLLEGE

Exploratory - Academic Advising and Retention Center

Computer Information Technology

Interdisciplinary Studies

South Campus - Academic Support

South Campus - Liberal Arts and Sciences

South Campus - Professional Studies

Systems Management

Women's Studies

\section{PART IV}

Part IV of this Inventory concerns your ideal academic advising experience. Please respond to the statements in terms of how you would most like to experience academic advising. As in Part I, there are 14 pairs of statements in Part IV.

29. My advisor is interested in helping me learn how to find out about courses and programs for myself.

Very

True Slightly

True

$0 \quad 0 \quad 0 \quad 0$

30. My advisor tells me what would be the best schedule for me.

Very Slightly

True

True

O

0

0

O
OR My advisor tells me what I need to know about academic courses and programs.

$\begin{array}{cccc}\text { Slightly } & & & \begin{array}{c}\text { Very } \\ \text { True } \\ \text { True }\end{array} \\ 0 & 0 & 0 & 0\end{array}$

OR My advisor suggests important considerations in planning a schedule and then gives me responsibility for the final decision.

Slightly

True

Very

True 
31. My advisor and I talk about vocational opportunities in conjunction with advising.

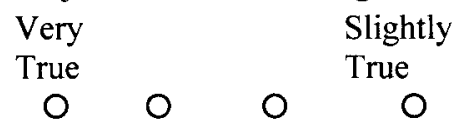

32. My advisor shows an interest in my outside-of-class activities and sometimes suggests activities.

Very

True

Slightly

O

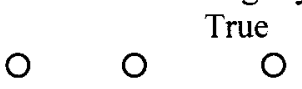

33. My advisor assists me in identifying realistic academic goals based on what I know about myself, as well as about my test scores and grades.

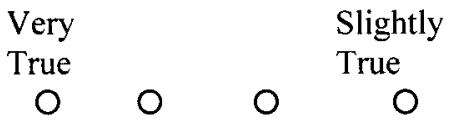

34. My advisor registers me for my classes.

Very

True

Slightly

$$
\text { O }
$$$$
\text { True }
$$

\section{O}

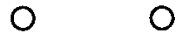

35. When I'm faced with difficult decisions my advisor tells me my alternatives and which one is the best choice.

Very

True

Slightly

$$
\text { O }
$$

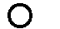

36. My advisor does not know who to contact about other-thanacademic problems.

Very

True

Slightly

0

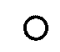

0

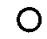

37. My advisor gives me tips on managing my time better or on studying more effectively when I seem to need them.
Very
True
Slightly
0

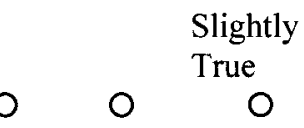

38. My advisor tells me what I must do in order to be advised.

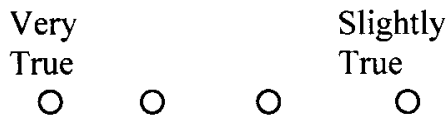

39. My advisor suggests what I should major in.
OR My advisor and I do not talk about vocational opportunities in conjunction with advising.

$\begin{array}{cccc}\text { Slightly } & & & \begin{array}{c}\text { Very } \\ \text { True }\end{array} \\ 0 & 0 & 0 & 0\end{array}$

OR My advisor does not know what I do outside of class.

$\begin{array}{cccc}\text { Slightly } & & \begin{array}{c}\text { Very } \\ \text { True } \\ \text { True }\end{array} & 0\end{array}$

OR My advisor identifies realistic academic goals for me based on my test scores and grades.
Slightly
Very
True

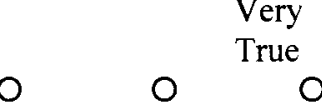

OR My advisor teaches me how to register

\begin{tabular}{|c|c|c|}
\hline Slightly & & \\
\hline True & & \\
\hline
\end{tabular}
myself for classes.

OR When I'm faced with difficult decisions, my advisor assists me in identifying alternatives and in considering the consequences of choosing each alternative.

Slightly

Very

True

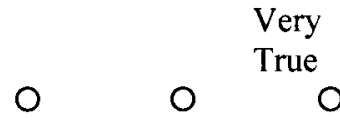

OR My advisor knows who to contact about other-than-academic problems.
Slightly
True

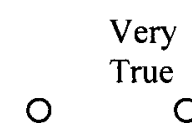

OR My advisor does not spend time giving me tips on managing my time better or on studying more effectively.

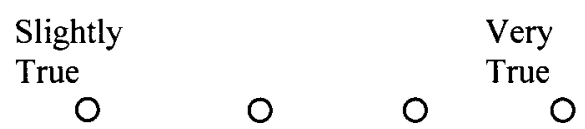

OR My advisor and I discuss our expectations of advising and of each other.

$\begin{array}{llll}\begin{array}{l}\text { Slightly } \\ \text { True }\end{array} & & \begin{array}{c}\text { Very } \\ \text { True }\end{array} \\ 0 & 0 & 0 & 0\end{array}$

OR My advisor suggests steps I can take to help me decide on a major. 
$\begin{array}{cccc}\text { Very } & & & \begin{array}{c}\text { Slightly } \\ \text { True } \\ \text { True }\end{array} \\ 0 & 0 & 0 & 0\end{array}$

40. My advisor uses test scores and grades to let him or her know what courses are most appropriate for me to take.

Very

True

O $0 \quad 0$

41. My advisor talks with me about my other-than-academic interests and plans.

$\begin{array}{cccc}\text { Very } & & & \begin{array}{c}\text { Slightly } \\ \text { True } \\ \text { True }\end{array} \\ 0 & 0 & 0 & 0\end{array}$

42. My advisor keeps mi informed of my academic progress by examining my files and grades only.

Very

True Slightly True
Slightly

True

0

OR My advisor and I use information, such as test scores, grades, interests, and abilities, to determine what courses are most appropriate for me to take.

$\begin{array}{llll}\text { Slightly } & & & \begin{array}{c}\text { Very } \\ \text { True } \\ \text { True }\end{array} \\ 0 & 0 & 0 & 0\end{array}$

OR My advisor does not talk with me about interests and plans other than academic ones.

Slightly

True<smiles>O</smiles>

OR My advisor keeps me informed of my academic progress by examining my files and grades and by talking to me about my classes. Slightly True
Very

True

\section{You have completed the survey.}

If you would like to enter your name in a drawing for one of three VISA gift cards valued at $\$ 100, \$ 50$, and $\$ 25$, please click on the URL below. You will be redirected to a form where you will simply provide your name, a current telephone number, and your campus address. Your personal information cannot be tied to your survey responses.

\section{https://wku.qualtrtics.com/entry-form}

Thank you, sincerely, for taking time from your busy schedule to respond to the survey. 


\section{CURRICULUM VITAE}

\section{Gladys Patricia Jordan, Ph.D.}

453 Grise Hall, WKU

1906 College Heights Blvd.

Bowling Green, KY 42101

pat.jordan@wku.edu
212 Rhoads Lane

Bowling Green, KY 42104

270.745.5464 (work)

270.799 .9543 (cell)

\section{EDUCATION}

Ph.D.

May 2012
University of Louisville

Department of Leadership, Foundations \& Human Resource Education

UofL-WKU Cooperative Doctoral Program

Major Area: Postsecondary Administration

Dissertation Chair: Sam Evans

Dissertation: Advising Style Preferences and Perceptions of Students and Advisors
M.B.A.

December 2002

B.A

December 1999
Western Kentucky University

Gordon Ford College of Business

Western Kentucky University

Department of Sociology

Major:

Sociology

Minors:

Magna cum laude
Business Administration

Computer Information Systems

3.68/4.0

A.S.

May 1983

Sullivan Junior College of Business (now Sullivan University)

Major area:

Computer Science

Cum laude

\section{TEACHING EXPERIENCE}

Fall 2008 - present

Adjunct Instructor, Gordon Ford College of Business, WKU Freshman Experience Business/Introduction to Business A multi-disciplinary introduction to entrepreneurship and the general business environment. Topics include study skills, critical thinking and problem solving, and exploration of majors and careers. Special attention is given to educational requirements, careers, and resources available to the business arena. 


\section{PRESENTATIONS}

Jordan, G. \& Patterson, S. (2007). Three-tiered advising. Presentation selected by the National Academic Advising Association (NACADA) - Region 3 Conference Committee and presented at the annual regional meeting in Asheville, NC.

Jordan, G. (2010). Why advising is important. Invited presentation for the Campus Advising Network - WKU.

\section{SERVICE}

College

2011

2011-present

2011-present

2009

2010-present

2009-2010

2009-2011

2009-2011

2008-present

2006

2006-present

2006-present

2005

1998-2001

University

2010

2009-present

2006

2003-2006

2003-2006
Search Committee Member Associate Dean

Civility Committee Member

Recruitment and Retention Committee Co-chair

Search Committee Chair

Academic Advisor (12 month position)

BA 175 Planning Committee Chair

BA 175 Planning Committee Member

Academic Advising Committee Chair

Global Studies Committee Member

United Way Representative

Search Committee Chair

Academic Advisor (10 month position)

Strategic Planning Committee Member

Curriculum Committee, Ex Officio member

Search Committee Member

Academic Advisor (9 month position)

Curriculum Committee Secretary; 1998-2001

Search Committee Member

Orientation Specialist - Academic Transitions Program

Academic Transitions Program - On The Road Committee Member

Women's Studies Community Outreach Committee Member

Board of Regents, Staff Regent (elected position)

Staff Regent, Associated Committee Service: Staff Excellence Awards Committee, Fall Break Brunch Committee, Summit Awards

Committee 
2004-2005 Search Committee Member

Director, Academic Advising and Retention

2000-2003 University Benefits Committee Member

2002 Enrollment Growth Committee Member

$2000 \quad$ Search Committee Member

WKU Benefits Manager

1997-1998 Women's Advisory Committee to the President

1993 Human Resources Staff Alignment Committee Member

Field

2011-2012 Volunteers Chair - 2012 National Conference

National Academic Advising Association

2009-2010 Founding Member

Kentucky Academic Advising Association (KACADA)

Community

2007

2006

2001-2004

2001-2002

2001-present

2001-present
Relay for Life, WKU Planning Committee

Relay for Life Team, Captain

American Heart Walk Team, Member

American Heart Walk Team, Captain

DECA Regional Competition, Judge

FBLA Regional Competition, Judge

PROFESSIONAL DEVELOPMENT

2004-2011 National Academic Advising Association - Annual and Regional Conferences

2010-2011 Kentucky Academic Advising Association (KACADA) - Annual Conferences

2004, 2006 Assessment of Academic Advising Institute (NACADA)

2003

Governor's Conference on Postsecondary Education Trusteeship

2003

Kentucky Long Term Policy Research Center's $10^{\text {th }}$ Annual Conference "Prospects for Kentucky's Educational Future"

\section{PROFESSIONAL ORGANIZATION MEMBERSHIPS}

2010-present

2010-present

2009-present

2006-present
American Association of Colleges and Universities

American College Personnel Association (ACPA)

Kentucky Academic Advising Association, Member

Campus Advising Network 
2005-present

2004-present

2003-2006

1996-present
American Association of University Women

National Academic Advising Association

Association of Governing Boards of Universities and Colleges

Alpha Kappa Delta Honor Society

OTHER WORK EXPERIENCE

Western Kentucky University - 1991-present

2006-present Coordinator, Undergraduate Student Services and Academic Advising

Gordon Ford College of Business

Supervise advisors, office staff, and student assistants. Advise undergraduates. Conduct orientation programs. Monitor admission standards for the college including students in violation of college policies. Audit student files to ensure accuracy of records.

Academic Advisor, Office of Student Services Gordon Ford College of Business

Advised students. Maintained student records and transfer course database. Maintained database of approved transfer courses from other universities to GFCOB. Audited student files to ensure accuracy of records. Trained incoming advisors.

$1997-2001$

Office Associate, Instructional Research \& Support Office (IRSO) Gordon Ford College of Business

Designed, organized and opened the IRSO. Performed various tasks for 60+ faculty members as well as personnel in the Dean's Office of the College. Duties included use of word processing, presentation, spreadsheet, and data base software to provide faculty with presentations, properly formatted journal articles, vitae, and brochures. Maintained office records; tracked requests for service; trained office staff and student assistants.

1993-1997 Office Associate, Department of Marketing College of Business Administration Managed academic departmental office. Advised students on class choices and major/minor requirements. Utilized customer service skills, word processing skills, and problem solving skills.

1991-1993 Office Assistant, Center for Excellence College of Education and Behavioral Sciences Managed a fast paced office that dealt with training in education. Utilized customer service skills, word processing skills, and problem solving skills. 
HONORS AND AWARDS

2006-2007 PRIDA Award for Student Services

2003-2004 Recent Alumni Achievement Award

1997 Outstanding Undergraduate Student

Department of Sociology 